In cooperation with the U.S. Army Corps of Engineers, Fort Worth District; City of Corpus Christi; Guadalupe-Blanco River Authority; San Antonio River Authority; and San Antonio Water System

Simulation of Streamflow and Suspended-Sediment Concentrations and Loads in the Lower Nueces River Watershed, Downstream from Lake Corpus Christi to the Nueces Estuary, South Texas, 1958-2008

Scientific Investigations Report 2010-5194 
Cover: Aerial photograph of the Nueces River and Nueces Estuary downstream from Interstate Highway 37, near Corpus Christi, Texas. 


\section{Simulation of Streamflow and Suspended- Sediment Concentrations and Loads in the Lower Nueces River Watershed, Downstream from Lake Corpus Christi to the Nueces Estuary, South Texas, 1958-2008}

By Darwin J. Ockerman and Franklin T. Heitmuller

In cooperation with the U.S. Army Corps of Engineers, Fort Worth District;

City of Corpus Christi; Guadalupe-Blanco River Authority; San Antonio River Authority; and San Antonio Water System

Scientific Investigations Report 2010-5194 


\section{U.S. Department of the Interior \\ KEN SALAZAR, Secretary \\ U.S. Geological Survey \\ Marcia K. McNutt, Director}

U.S. Geological Survey, Reston, Virginia: 2010

This and other USGS information products are available at http://store.usgs.gov/
U.S. Geological Survey
Box 25286 , Denver Federal Center
Denver, CO 80225
To learn about the USGS and its information products visit http://www.usgs.gov/
1-888-ASK-USGS

Any use of trade, product, or firm names is for descriptive purposes only and does not imply endorsement by the U.S. Government.

Although this report is in the public domain, permission must be secured from the individual copyright owners to reproduce any copyrighted materials contained within this report.

Suggested citation:

Ockerman, D.J., and Heitmuller, F.T., 2010, Simulation of streamflow and suspended-sediment concentrations and loads in the lower Nueces River watershed, downstream from Lake Corpus Christi to the Nueces Estuary, South Texas, 1958-2008: U.S. Geological Survey Scientific Investigations Report 2010-5194, 50 p. 


\section{Contents}

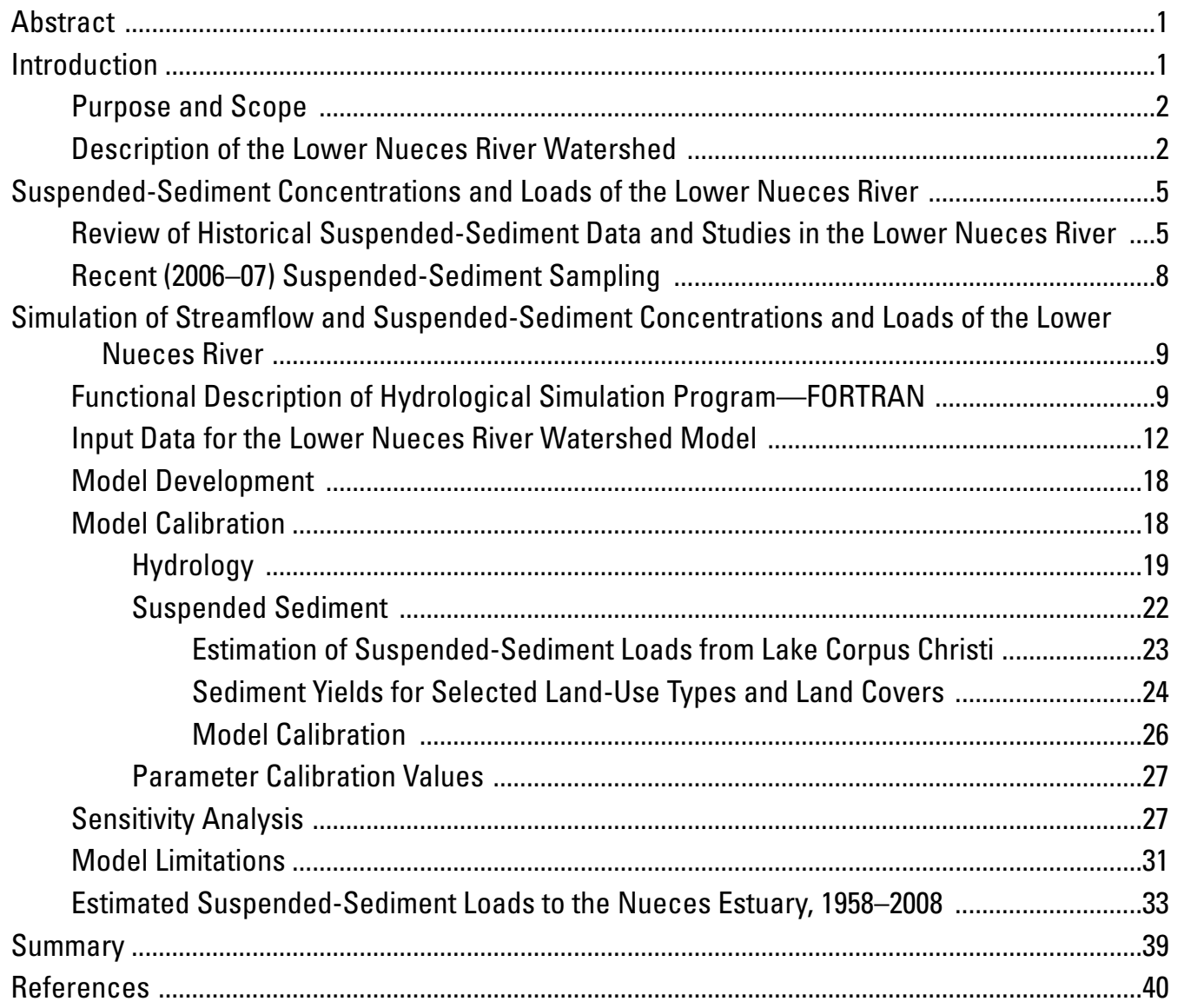

Appendix 1. Hydrological Simulation Program-FORTRAN (HSPF) Parameters Used to Simulate Hydrologic and Sediment Processes in the Lower Nueces River Watershed, South Texas

\section{Figures}

1-2. Maps showing:

1. Location of Nueces River Basin, including lower Nueces River study area, South Texas 3

2. Location of lower Nueces River watershed, South Texas .........................................

3. Graph showing annual suspended-sediment loads for the Nueces River near Mathis, Texas, 1942-57 and 1962-82

4. Hydrological Simulation Program-FORTRAN (HSPF) flowchart for hydrologic processes on $(A)$ impervious and $(B)$ pervious land segments

5. Hydrological Simulation Program-FORTRAN (HSPF) flowchart for sediment processes on $(A)$ impervious land segments, $(B)$ pervious land segments, and (C) stream reaches

6-10. Maps showing:

6. Land-cover categories in the lower Nueces River watershed, South Texas 
7. Surficial geology of the lower Nueces River watershed, South Texas

8. Relative soil infiltration rates in the lower Nueces River watershed, South Texas

9. Subwatershed delineation for the lower Nueces River watershed model, South Texas .

10. Locations of U.S. Geological Survey streamflow-gaging stations and National Weather Service rainfall stations (with associated Thiessen rainfall areas) providing data for the lower Nueces River watershed model, South Texas

11-16. Graphs showing:

11. Measured and simulated daily mean streamflow at U.S. Geological Survey streamflow-gaging station 08211200 Nueces River at Bluntzer, Texas, 2005-06

12. Measured and simulated 7-day mean streamflow at U.S. Geological Survey streamflow-gaging station 08211500 Nueces River at Calallen, Texas, 2001-08

13. Relation between streamflow and suspended-sediment load and plot of regression error residuals based on 22 streamflow-load data pairs from 08211000 Nueces River near Mathis, Texas, 1964-71 and 2006-07

14. Relation between streamflow and suspended-sediment load and plot of regression error residuals based on 10 streamflow-load data pairs from 08211500 Nueces River at Calallen, Texas, 2006-07

15. Estimated (by regression) and simulated monthly suspended-sediment loads for 08211500 Nueces River at Calallen, Texas, 2001-08

16. Estimated annual streamflow and suspended-sediment loads to the Nueces Estuary, South Texas, 1958-2008

\section{Tables}

1. Annual suspended-sediment loads for the Nueces River near Mathis, Texas, 1942-58 and 1961-82

2. Streamflow and suspended-sediment loads for selected flow releases from Wesley E. Seale Dam on the Nueces River near Mathis, Texas, October 1964September 1971

3. Data-collection sites providing data for the lower Nueces River watershed model, South Texas

4. Streamflow calibration and testing results for the lower Nueces River watershed model, South Texas

5. Measured and simulated streamflows, measured suspended-sediment particle size, and measured and simulated suspended-sediment concentrations and loads for selected samples collected at 08211000 Nueces River near Mathis, Texas, 2006-07

6. Comparison of literature estimates and simulation results for sediment yields from selected land covers and land uses in the lower Nueces River watershed and South Texas area

7. Measured and simulated streamflows, measured suspended-sediment particle size, and measured and simulated suspended-sediment concentrations and loads for selected samples collected at 08211200 Nueces River at Bluntzer, Texas, 2006-07 
8. Suspended-sediment calibration results for the Hydrological Simulation Program-FORTRAN model of the lower Nueces River watershed, South Texas, 2001-08

9. Measured and simulated streamflows, measured suspended-sediment particle size, and measured and simulated suspended-sediment concentrations and loads for selected samples collected at 08211500 Nueces River at Calallen, Texas, 2006-07

10. Summary of calibrated values for selected hydrologic parameters for the Hydrological Simulation Program-FORTRAN model of the lower Nueces River watershed, South Texas

11. Summary of calibrated values for selected sediment-related parameters for the Hydrological Simulation Program-FORTRAN model of the lower Nueces River watershed, South Texas

12. Sensitivity of simulated streamflow volumes and suspended-sediment loads to changes in selected process-related parameters for the lower Nueces River watershed model, South Texas

13. Estimated annual streamflows and suspended-sediment loads to the Nueces Estuary, South Texas, 1958-2008

14. Estimated annual suspended-sediment loads at selected stations, lower Nueces River watershed, South Texas, 1958-2008

15. Estimated annual streamflows and suspended-sediment loads, by sediment source, simulated by the Hydrological Simulation Program-FORTRAN model of the lower Nueces River watershed, South Texas, 1958-2008 


\section{Conversion Factors, Datum, and Water-Quality Abbreviation} Inch/Pound to SI

\begin{tabular}{|c|c|c|}
\hline Multiply & By & To obtain \\
\hline \multicolumn{3}{|c|}{ Length } \\
\hline inch (in.) & 25.4 & millimeter $(\mathrm{mm})$ \\
\hline foot $(\mathrm{ft})$ & 0.3048 & meter (m) \\
\hline mile (mi) & 1.609 & kilometer $(\mathrm{km})$ \\
\hline \multicolumn{3}{|c|}{ Area } \\
\hline acre & 0.4047 & hectare (ha) \\
\hline square mile $\left(\mathrm{mi}^{2}\right)$ & 2.590 & square kilometer $\left(\mathrm{km}^{2}\right)$ \\
\hline \multicolumn{3}{|c|}{ Volume } \\
\hline ounce, fluid (fl. oz) & 0.02957 & liter $(\mathrm{L})$ \\
\hline acre-foot (acre-ft) & 0.001233 & cubic hectometer $\left(\mathrm{hm}^{3}\right)$ \\
\hline \multicolumn{3}{|c|}{ Flow rate } \\
\hline cubic foot per second $\left(\mathrm{ft}^{3} / \mathrm{s}\right)$ & 0.02832 & cubic meter per second $\left(\mathrm{m}^{3} / \mathrm{s}\right)$ \\
\hline \multicolumn{3}{|c|}{ Mass } \\
\hline pound, avoirdupois (lb) & 0.4536 & kilogram $(\mathrm{kg})$ \\
\hline ton, short $(2,000 \mathrm{lb})$ & 0.9072 & megagram $(\mathrm{Mg})$ \\
\hline \multicolumn{3}{|c|}{ Pressure } \\
\hline pound per square foot $\left(\mathrm{lb} / \mathrm{ft}^{2}\right)$ & 0.04788 & kilopascal (kPa) \\
\hline \multicolumn{3}{|c|}{ Hydraulic gradient } \\
\hline foot per mile (ft/mi) & 0.1894 & meter per kilometer $(\mathrm{m} / \mathrm{km})$ \\
\hline \multicolumn{3}{|c|}{ Yield } \\
\hline pound per acre (lb/acre) & 1.121 & kilogram per hectare $\mathrm{kg} / \mathrm{ha}$ ) \\
\hline
\end{tabular}

Temperature in degrees Fahrenheit $\left({ }^{\circ} \mathrm{F}\right)$ may be converted to degrees Celsius $\left({ }^{\circ} \mathrm{C}\right)$ as follows:

$$
{ }^{\circ} \mathrm{C}=\left({ }^{\circ} \mathrm{F}-32\right) / 1.8
$$

\section{SI to Inch/Pound}

\begin{tabular}{lll}
\hline \multicolumn{1}{c}{ Multiply } & By & \multicolumn{1}{c}{ To obtain } \\
\hline & Length & \\
\hline millimeter $(\mathrm{mm})$ & 0.03937 & inch (in.) \\
meter $(\mathrm{m})$ & 3.281 & foot (ft) \\
\hline & Volume & \\
\hline milliliter $(\mathrm{mL})$ & 0.03382 & ounce, fluid (fl. oz) \\
\hline & Mass & \\
\hline kilogram $(\mathrm{kg})$ & 2.205 & pound avoirdupois (lb) \\
\hline
\end{tabular}

\section{Datum}

Horizontal coordinate information is referenced to the North American Datum of 1983 (NAD 83).

\section{Water-Quality Abbreviation}

$\mathrm{mg} / \mathrm{L}$, milligrams per liter 


\title{
Simulation of Streamflow and Suspended-Sediment Concentrations and Loads in the Lower Nueces River Watershed, Downstream from Lake Corpus Christi to the Nueces Estuary, South Texas, 1958-2008
}

\author{
By Darwin J. Ockerman and Franklin T. Heitmuller
}

\section{Abstract}

The U.S. Geological Survey (USGS), in cooperation with the U.S. Army Corps of Engineers-Fort Worth District, City of Corpus Christi, Guadalupe-Blanco River Authority, San Antonio River Authority, and San Antonio Water System, developed, calibrated, and tested a Hydrological Simulation Program-FORTRAN (HSPF) watershed model to simulate streamflow and suspended-sediment concentrations and loads during 1958-2008 in the lower Nueces River watershed, downstream from Lake Corpus Christi to the Nueces Estuary in South Texas. Data available to simulate suspended-sediment concentrations and loads consisted of historical sediment data collected during 1942-82 in the study area and suspendedsediment concentration data collected periodically by the USGS during 2006-07 at three USGS streamflow-gaging stations, Nueces River near Mathis, Nueces River at Bluntzer, and Nueces River at Calallen. The Nueces River near Mathis station is downstream from Wesley E. Seale Dam, completed in 1958 to impound Lake Corpus Christi. Suspended-sediment data collected before and after completion of Wesley E.

Seale Dam provide insights to the effects of the dam and reservoir on suspended-sediment loads transported by the lower Nueces River from downstream of the dam to the Nueces Estuary. Annual suspended-sediment loads at a site near the Nueces River at Mathis station were considerably lower, for a given annual mean discharge, after the dam was completed than before the dam was completed.

Most of the suspended sediment transported by the Nueces River downstream from Wesley E. Seale Dam occurred during high-flow releases from the dam or during floods. During October 1964-September 1971, about 532,000 tons of suspended sediment were transported by the Nueces River near Mathis. Of this amount, about 473,000 tons, or about 89 percent, were transported by large runoff events (mean streamflow exceeding 1,000 cubic feet per second).

To develop the watershed model to simulate suspendedsediment concentrations and loads in the lower Nueces River watershed during 1958-2008, streamflow simulations were calibrated and tested with available data for 2001-08 from the Nueces River at Bluntzer and Nueces River at Calallen stations. Streamflow data from the Nueces River near Mathis station were used as input to the model at the upstream boundary of the model. Simulated streamflow volumes for the Bluntzer and Calallen stations showed good agreement (within 6 percent) with measured streamflow volumes.

The HSPF model was calibrated to simulate suspended sediment using suspended-sediment data collected at the Mathis, Bluntzer, and Calallen stations during 2006-07. The calibrated watershed model was used to estimate streamflow and suspended-sediment loads for 1958-2008, including loads transported to the Nueces Estuary. During 1958-2008, on average, an estimated 307 tons per day of suspended sediment were delivered to the lower Nueces River; an estimated 297 tons per day were delivered to the estuary. The annual suspended-sediment load was highly variable, depending on the occurrence of storm events and high streamflows. During 1958-2008, the annual total sediment loads to the estuary varied from an estimated 3.8 to 2,490 tons per day. On average, 117 tons per day, or about 38 percent of the estimated annual suspended-sediment contribution, originated from cropland in the study watershed. Releases from Lake Corpus Christi delivered an estimated 98 tons per day of suspended sediment or about 32 percent of the 307 tons per day estimated to have been delivered to the lower Nueces River. Erosion of streamchannel bed and banks accounted for 55 tons per day or about 18 percent of the estimated total suspended-sediment load. All other land categories, except cropland, accounted for an estimated 37 tons per day, or about 12 percent of the total. An estimated 9.6 tons per day of suspended sediment or about 3 percent of the suspended-sediment load delivered to the lower Nueces River were removed by water withdrawals before reaching the Nueces Estuary.

\section{Introduction}

The Nueces River extends approximately 315 miles from its headwaters in the southern Edwards Plateau in South Texas to Nueces Bay near Corpus Christi, Tex., and has a drainage 
area of approximately 16,700 square miles (fig. 1). The river exits the Edwards Plateau near Uvalde, Tex., and enters the South Texas Plains, also referred to as the South Texas Brush Country (Texas Parks and Wildlife Department, 2007), where the majority of its length and drainage area are located. The Frio River, a major tributary, joins the Nueces River near Three Rivers, Tex. Major impoundments in the Nueces River watershed in the South Texas Plains include Upper Nueces Reservoir, formed in 1948 by Upper Nueces Dam; Choke Canyon Reservoir, formed in 1982 by Choke Canyon Dam (on the Frio River); and Lake Corpus Christi, impounded by Mathis Dam in 1935 (surface area 5,493 acres, storage volume 43,800 acre-feet) (Texas Water Development Board, 2002) and impounded since 1958 by Wesley E. Seale Dam (surface area 19,251 acres, storage volume 257,260 acre-feet) (City of Corpus Christi, 2010). Downstream from Wesley E. Seale Dam (fig. 2), the Nueces River flows about 50 miles through an alluvial valley to the Nueces Bay.

The Nueces Estuary (fig. 2) consists of two areas of nearly equal size, Nueces Bay and the Nueces River delta. Nueces Bay is a shallow, 27-square-mile secondary bay of Corpus Christi Bay. Nueces Bay has a mean depth of about 2.5 feet and a volume of about 40,000 acre-feet. Bottom sediments in Nueces Bay are deposited mostly by the Nueces River (Yeager and others, 2006). The Nueces River delta in southern San Patricio County is a 28-square-mile area of vegetated salt and brackish marshes, land subject to inundation from river or tidal flooding, and open water formed where the Nueces River flows into Nueces Bay (fig. 2). Currently (2010), the Nueces River channel is located along the southern margins of the delta. The distributary network includes a man-made overflow channel in the northwestern part of the delta that connects the Nueces River to Rincon Bayou (U.S. Bureau of Reclamation, 2000; Ockerman, 2001).

In November 2005, during a resource agency meeting in San Antonio, Tex., the U.S. Army Corps of Engineers (USACE) highlighted 12 ecological problems in the Nueces River watershed. One of these was a "loss of sediment loading and nutrient loads to estuaries" (Marcia Hackett, U.S. Army Corps of Engineers-Fort Worth District, written commun., 2005). A number of the other ecological problems were directly related, including a reduction of overbank flows downstream from reservoirs and decrease in freshwater inflows to the Nueces Estuary. The reduction in sediment loads to the Nueces Estuary is the result of sedimentation in large impoundments, notably Lake Corpus Christi (Leibbrand, 1987). Downstream from the reservoirs, ecological problems caused by sedimentation impoundment are expected to include river channel incision (Williams and Wolman, 1984; Salant and others, 2006), channel bed armoring (Williams and Wolman, 1984; Vericat and others, 2006), and deltaic and shoreline erosion (Jaffe and others, 1998; Fan and others, 2006; Yang and others, 2006). Reductions in the extent of marshland and vegetated areas in the Nueces River delta occurred following the initial impoundment of Lake Corpus Christi (Morton and Paine 1984; White and Calnan,
1991). The decreased sediment loads of the Nueces River, combined with relative sea level rise and subsidence are responsible for deltaic erosion and the conversion of wetland habitat to open water and shallow flats (Day and others, 1995; White and others, 2002; Yeager and others, 2006).

The USACE-Fort Worth District began a study in 2002 to identify opportunities for flood-damage reduction, ecosystem restoration, and implementation of multipurpose projects in the Nueces River Basin (U.S. Army Corps of Engineers, 2009). The purpose of the USACE study was to participate with other (Federal and non-Federal) sponsor agencies to identify and conduct detailed studies of water-resource problems in the Nueces River Basin (fig. 1), including documenting existing hydrologic, engineering, and environmental conditions of the study area. One of the specific feasibility investigations outlined in the USACE study was related to defining the existing conditions and opportunities for ecosystem restoration in the Nueces Estuary, namely an investigation of the current conditions of suspended-sediment concentrations and loads delivered by the Nueces River to the estuary. As part of this feasibility study, the U.S. Geological Survey (USGS), in cooperation with the USACE-Fort Worth District, City of Corpus Christi, Guadalupe-Blanco River Authority, San Antonio River Authority, and San Antonio Water System, developed, calibrated, and tested a watershed model of the lower Nueces River watershed to simulate existing hydrologic conditions and suspended-sediment concentrations and loads to the Nueces Estuary.

\section{Purpose and Scope}

The purpose of this report is to estimate suspendedsediment concentrations and loads in the lower Nueces River watershed downstream from Lake Corpus Christi to the Nueces Estuary during 1958-2008. To accomplish this, (1) previous suspended-sediment data and studies for the study area were reviewed; (2) historic estimates of suspendedsediment loads were compiled; and (3) a watershed model to simulate streamflow and suspended-sediment concentrations and loads in the lower Nueces River watershed was developed and calibrated. Using the watershed model, estimates of suspended-sediment loads to the Nueces Estuary for 1958-2008 were prepared. Limitations of model-simulated estimates of sediment loads are described.

\section{Description of the Lower Nueces River Watershed}

The lower Nueces River study area comprises about 216 square miles of the nontidal part of the Nueces River watershed, from the outlet of Wesley E. Seale Dam near Mathis (fig. 2) to the tidal reach of the river that flows into the Nueces Estuary. The study area encompasses parts of Bee, Jim Wells, Live Oak, Nueces, and San Patricio Counties in South Texas. 

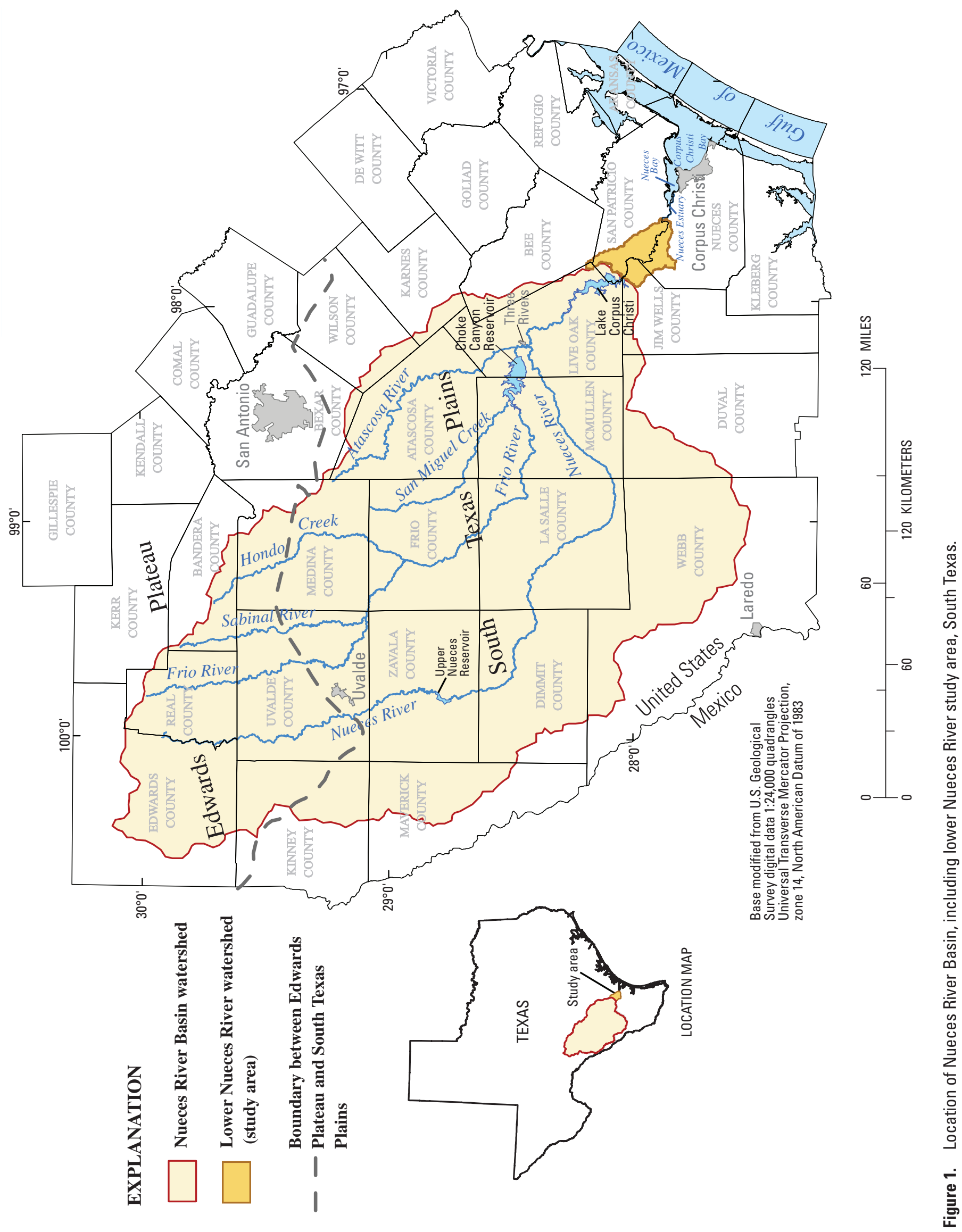


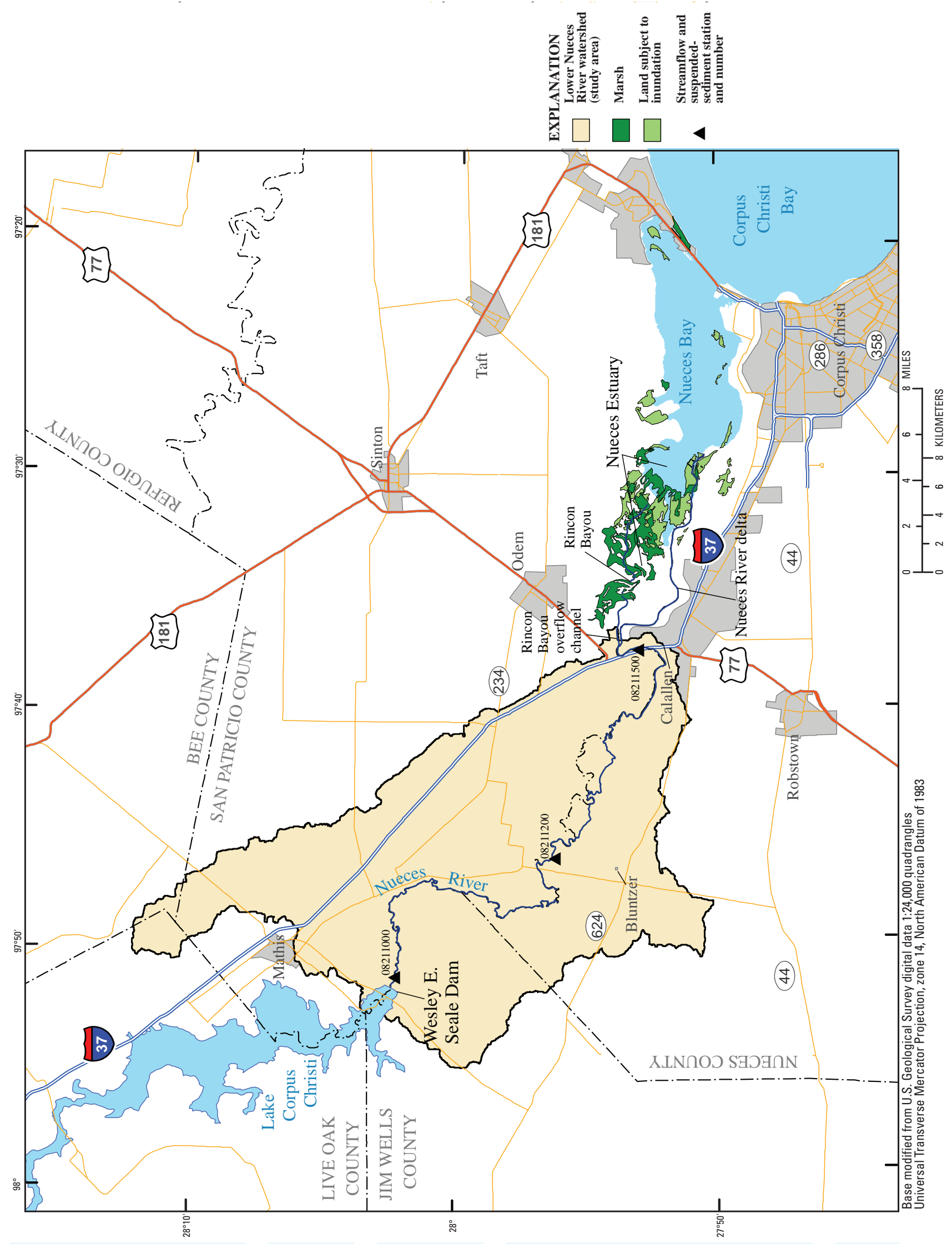

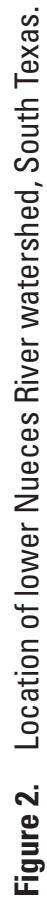


The largest town in the study area is Mathis, Tex., which had a population of about 5,000 in 2000 (Handbook of Texas Online, 2009).

The study area has a subtropical, subhumid climate characterized by hot summers and mild, dry winters (Larkin and Bomar, 1983). The average monthly low temperatures range from 46.2 degrees Fahrenheit $\left({ }^{\circ} \mathrm{F}\right)$ in January to $74.5^{\circ} \mathrm{F}$ in August; average daily high temperatures range from 66.0 ${ }^{\circ} \mathrm{F}$ in January to $93.4^{\circ} \mathrm{F}$ in August (National Climatic Data Center, 2009). The average annual rainfall (1971-2000) in the study area is about 32.6 inches (32.2 inches at Mathis National Weather Service [NWS] station COOP ID 415661 and 32.9 inches at Robstown NWS station COOP ID 417677). Daily rainfall greater than 0.01 inch occurs, on average, 72 days per year (National Climatic Data Center, 2009); daily rainfall equal to or greater than 1.0 inch occurs, on average, every 39 days (Asquith and Roussel, 2003). Although most rainfall occurs in spring, early summer, and fall, amounts greater than about 1.0 inch can occur anytime during the year (Larkin and Bomar, 1983).

Most land use is rangeland and cropland. Elevation in the lower Nueces River watershed ranges from about 3 to 230 feet above sea level (U.S. Geological Survey, 2001). Land slopes are generally low, mostly less than 5 percent. Overall, the stream-channel slope of the lower Nueces River is about 1 foot per mile over the 38 miles from the outlet of Wesley E. Seale Dam to the river crossing at Interstate Highway 37, north of Corpus Christi (fig. 2).

\section{Suspended-Sediment Concentrations and Loads of the Lower Nueces River}

Characterizing suspended-sediment concentrations and loads in the lower Nueces River included the following major steps: (1) A review of the available suspended-sediment concentration and load data and studies, including a compilation of historical estimates of suspended-sediment loads; (2) development and calibration of a watershed model to simulate suspended-sediment concentrations and loads in the lower Nueces River watershed; and (3) estimation of suspendedsediment loads to the Nueces Estuary for 1958-2008.

\section{Review of Historical Suspended-Sediment Data and Studies in the Lower Nueces River}

Various studies have investigated the problems associated with the reduction in sediment loads to the Nueces Estuary and the associated loss of wetland habitats in the Nueces River delta. Morton and Paine (1984) used aerial photographs to show that the propagation of deltaic wetlands in the Nueces River delta ceased sometime between 1930 and 1959. These findings were substantiated by White and Calnan (1990), who also showed an additional decrease in net vegetated areas by 1979. As further support to the importance of sediment transport in maintaining the Nueces River delta, Leibbrand (1987) showed that almost all sediment entering Lake Corpus Christi between 1972 and 1985 was trapped. Recent studies showed that loss of wetlands in the Nueces Estuary not only was the result of upstream impoundments but also was influenced by gradual subsidence of the delta (White and others, 2002). As a consequence of these two factors, White and others (2002) also predicted that wetland areas would continue to decrease in the Nueces River delta. Finally, Yeager and others (2006) showed that sediment in Nueces Bay is supplied mostly by the river rather than by marine sources (transport from the Gulf of Mexico by wind or tidal currents), supporting claims that a reduction of suspended-sediment inflow from the Nueces River will contribute to loss of Nueces Estuary wetland habitat.

In 1924, the Texas Board of Water Engineers (whose name and functions were subsequently changed several times by the Texas Legislature and whose functions unrelated to water rights were transferred to the Texas Water Development Board [TWDB] in 1965) initiated a program to evaluate the economic life of reservoirs, which included monitoring suspended-sediment loads in selected Texas rivers (Stout and others, 1961; Mirabal, 1974). During the program, the USGS (in 1942) established one site in the lower Nueces River study area (fig. 2), streamflow-gaging station 08210000 Nueces River near Mathis, Tex. (hereinafter, Mathis gage). Suspended-sediment concentration samples were collected on a daily basis at this site by TWDB and its predecessor agencies; monthly and annual suspended-sediment concentration data and sediment loads (using streamflow data from the Mathis gage) were computed until 1982 and published by various authors, including Stout and others (1961), Adey and Cook (1964), Cook (1967, 1970), Mirabal (1974), Dougherty (1979), and Quincy (1988).

Records for June 1958-June 1961 were invalid (Adey and Cook, 1964) and were not used for interpretation in this report. Suspended-sediment samples were collected during 1942-82 using an 8-ounce (236.3-milliliter) narrow-neck bottle which was held in a 10-pound (4.54-kilogram) torpedo-shaped sampler frame positioned approximately 1 foot $(0.3$ meter) below the water surface. Samples were collected either daily or throughout the day if the stage changed considerably. Samples were collected at one-sixth, one-half, and five-sixths of the water-surface width using a sampling device called the "Texas sampler" (Stout and others, 1961; Welborn, 1967). To account for increasing suspended-sediment concentrations with depth, the measured percentage of suspended sediment by weight was multiplied by a correction factor of 1.102 to obtain the mean percentage of suspended sediment in the vertical profile (Farris, 1933). Suspended-sediment loads were computed with the assumptions that 1 acre-foot of streamflow weighed 1,361.25 tons and 1 acre-foot of sediment weighed 1,524.60 tons (Stout and others, 1961). Since 1982, most sediment data have been collected as part of relatively short-term studies for selected river reaches (for example, Phillips and others, 2005; Yeager and others, 2005). 


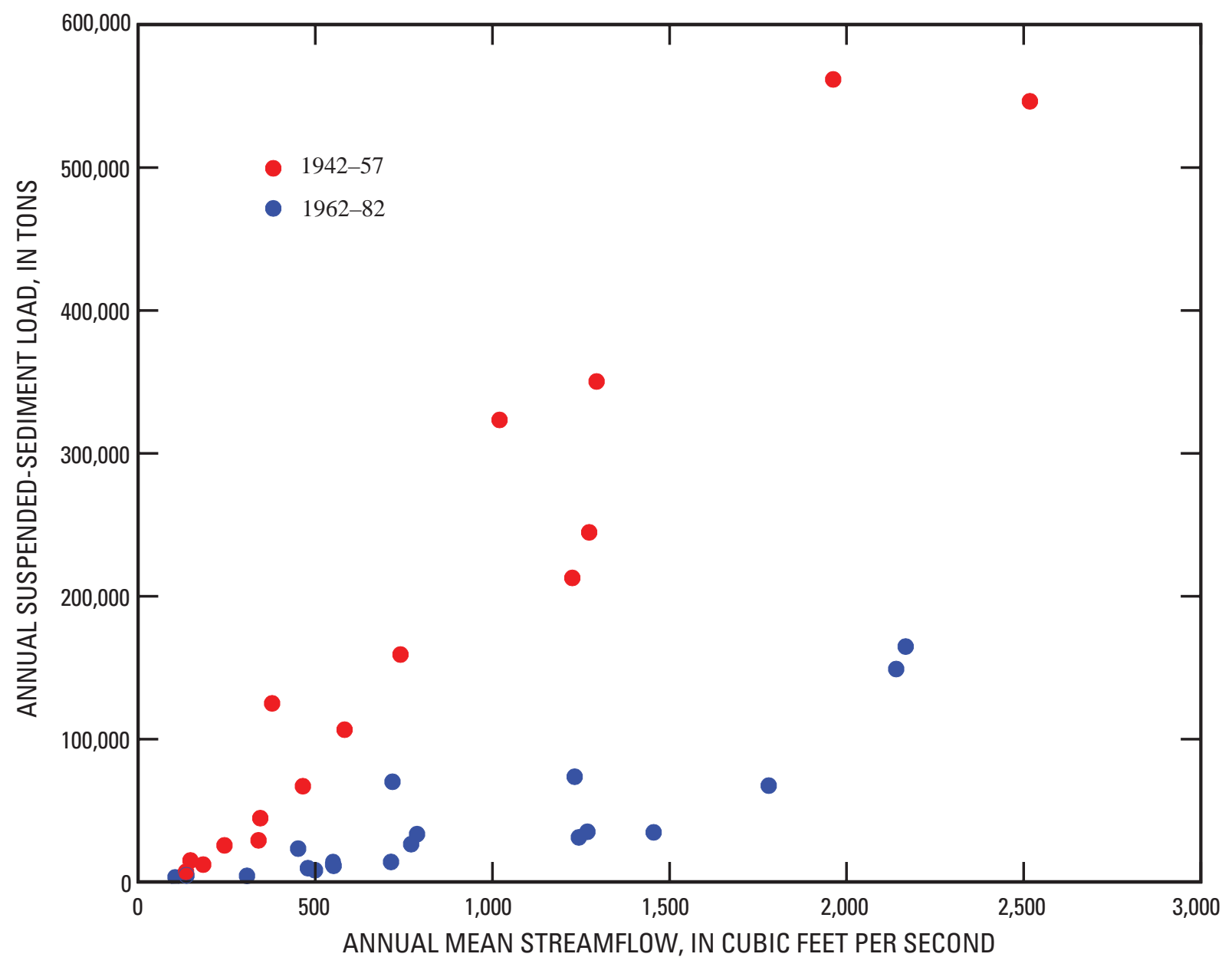

Figure 3. Annual suspended-sediment loads for the Nueces River near Mathis, Texas, 1942-57 and 1962-82.

To verify the accuracy of the suspended-sediment sampling method described in the previous paragraph, referred to hereinafter as the "Texas sampler method," Welborn (1967) compared the results of samples collected from various Texas streams by the Texas sampler method with results of concurrent samples collected by a depth-integrated method (Edwards and Glysson, 1999). Correlations between the two methods for sand-bed rivers in East Texas were poor but were very good (differing by 15 percent or less) for mixed-bed and gravel-bed rivers. The lower Nueces River is a mixed sand- and gravelbed channel; therefore, suspended-sediment data collected using the Texas sampler method were deemed reasonably accurate for computation of historical loads.

Suspended-sediment data collected before and after completion of Wesley E. Seale Dam provide insights to the effects of the dam and reservoir on suspended-sediment loads transported by the lower Nueces River from downstream of the dam to the Nueces Bay. Suspended-sediment loads (fig. 3; table 1) measured by TWDB and its predecessor agencies at the Mathis gage decreased appreciably in the years after completion of Wesley E. Seale Dam in 1958. During 9 of the
16 years before completion of the dam, annual suspendedsediment loads exceeded 100,000 tons. The maximum annual suspended-sediment load for the period of record was 561,739 tons in 1957, an amount that likely was larger compared with loads for all previous years because of the erosion of sediment during construction of Wesley E. Seale Dam immediately upstream from the suspended-sediment sampling site. In the 21 years following completion of the dam, for which reliable suspended-sediment data were available (1962-82), more than 100,000 tons of suspended sediment were transported in only 2 years -1967 and 1971 . These 2 years were characterized by relatively high annual mean streamflows at the Mathis gage2,167 and 2,140 cubic feet per second in 1967 and 1971, respectively. During 1962-82, annual suspended-sediment loads were considerably lower, for a given annual mean discharge, than in the years before the dam was completed (fig. 3 ; table 1). The relation between annual suspended-sediment loads and annual mean streamflow before and after completion of Wesley E. Seale Dam is shown on figure 3. As an indication of the sediment-retention capacity of the dam, for comparable annual mean discharges, annual suspended-sediment loads 
Table 1. Annual suspended-sediment loads for the Nueces River near Mathis, Texas, 1942-58 and 1961-82 (from Stout and others, 1961; Adey and Cook, 1964; Cook, 1967, 1970; Mirabal, 1974).

\begin{tabular}{|c|c|c|c|c|}
\hline Hydrologic year ${ }^{1,2}$ & $\begin{array}{l}\text { Number of days measured } \\
\text { during hydrologic year }\end{array}$ & $\begin{array}{l}\text { Annual suspended- } \\
\text { sediment load } \\
\text { (tons) }\end{array}$ & $\begin{array}{l}\text { Annual mean suspended- } \\
\text { sediment load } \\
\text { (tons per day) }\end{array}$ & $\begin{array}{l}\text { Annual mean streamflow } \\
\text { (cubic feet per second) }\end{array}$ \\
\hline 1942 & 241 & 546,504 & 2,268 & 2,517 \\
\hline 1943 & 365 & 44,790 & 123 & 345 \\
\hline 1944 & 366 & 323,550 & 884 & 1,020 \\
\hline 1945 & 365 & 125,070 & 343 & 378 \\
\hline 1946 & 365 & 350,430 & 960 & 1,294 \\
\hline 1947 & 365 & 244,730 & 670 & 1,273 \\
\hline 1948 & 366 & 15,170 & 41 & 148 \\
\hline 1949 & 365 & 212,770 & 583 & 1,226 \\
\hline 1950 & 365 & 29,160 & 80 & 340 \\
\hline 1951 & 365 & 106,740 & 292 & 583 \\
\hline 1952 & 366 & 25,670 & 70 & 244 \\
\hline 1953 & 365 & 159,200 & 436 & 741 \\
\hline 1954 & 365 & 67,020 & 184 & 465 \\
\hline 1955 & 365 & 7,269 & 20 & 135 \\
\hline 1956 & 366 & 12,165 & 33 & 184 \\
\hline 1957 & 365 & 561,739 & 1,539 & 1,962 \\
\hline 1958 & 243 & 395,791 & 1,629 & 2,179 \\
\hline 1961 & 92 & 2,088 & 23 & 373 \\
\hline 1962 & 365 & 2,845 & 8 & 111 \\
\hline 1963 & 365 & 2,769 & 8 & 110 \\
\hline 1964 & 366 & 3,445 & 9 & 104 \\
\hline 1965 & 365 & 33,642 & 92 & 787 \\
\hline 1966 & 365 & 23,400 & 64 & 452 \\
\hline 1967 & 365 & 177,600 & 48 & 2,167 \\
\hline 1968 & 366 & 73,640 & 201 & 1,232 \\
\hline 1969 & 365 & 4,810 & 13 & 136 \\
\hline 1970 & 365 & 70,290 & 193 & 718 \\
\hline 1971 & 365 & 149,100 & 408 & 2,140 \\
\hline 1972 & 366 & 67,530 & 185 & 1,780 \\
\hline 1973 & 365 & 14,030 & 38 & 714 \\
\hline 1974 & 365 & 31,370 & 86 & 1,244 \\
\hline 1975 & 365 & 11,450 & 31 & 552 \\
\hline 1976 & 366 & 12,460 & 34 & 550 \\
\hline 1977 & 365 & 34,830 & 95 & 1,455 \\
\hline 1978 & 365 & 4,280 & 12 & 307 \\
\hline 1979 & 365 & 8,210 & 22 & 499 \\
\hline 1980 & 366 & 26,560 & 73 & 771 \\
\hline 1981 & 365 & 35,190 & 96 & 1,268 \\
\hline 1982 & 365 & 9,790 & 27 & 479 \\
\hline
\end{tabular}

${ }^{1}$ A hydrologic year begins October 1 of previous calendar year and ends September 30 of reported year.

${ }^{2}$ Data for June 1958-June 1961 are invalid (Adey and Cook, 1964) and are not included. 
after completion of the dam have been consistently lower compared with annual suspended-sediment loads before completion of the dam (fig. 3).

Most of the suspended sediment transported by the Nueces River downstream from Wesley E. Seale Dam occurred during high-flow releases from the dam or during floods. During October 1964-September 1971, about 532,000 tons of suspended sediment were transported by the Nueces River near Mathis (table 1). Of this amount, about 473,000 tons (table 2), or about 89 percent, were transported by large runoff events (mean streamflow exceeding 1,000 cubic feet per second). Furthermore, the suspended-sediment transport rate increases with higher magnitude flows (fig. 3). The largest flow event listed in table 2 (September 21-October 11, 1967) transported a mean of 8,872 tons of suspended sediment per day.

\section{Recent (2006-07) Suspended-Sediment Sampling}

In addition to historical suspended-sediment data collected daily by TWDB and its predecessor agencies at the Mathis gage during 1942-82, the USGS periodically collected suspended-sediment samples during 2006-07 at the Mathis

Table 2. Streamflow and suspended-sediment loads for selected flow releases from Wesley E. Seale Dam on the Nueces River near Mathis, Texas, October 1964-September 1971 (from Cook, 1970; Mirabal, 1974).

\begin{tabular}{lrrc}
\hline \multicolumn{1}{c}{ Event } & $\begin{array}{c}\text { Mean } \\
\text { stream- } \\
\text { flow } \\
\text { (cubic } \\
\text { feet per } \\
\text { second) }\end{array}$ & $\begin{array}{c}\text { Suspended- } \\
\text { sediment } \\
\text { load } \\
\text { (tons) }\end{array}$ & $\begin{array}{c}\text { Mean } \\
\text { suspended- } \\
\text { sediment } \\
\text { load } \\
\text { (tons per } \\
\text { day) }\end{array}$ \\
\hline October 5-16, 1964 & 7,425 & 7,506 & 682 \\
February 24-March 11, 1965 & 2,727 & 3,939 & 246 \\
May 20-June 11, 1965 & 4,465 & 15,541 & 676 \\
May 2-June 10, 1966 & 2,980 & 18,653 & 466 \\
September 21-October 11, 1967 & 35,129 & 186,302 & 8,872 \\
October 16-30, 1967 & 1,545 & 4,318 & 288 \\
January 21-February 11, 1968 & 5,492 & 14,802 & 673 \\
May 8-June 5, 1968 & 4,970 & 15,806 & 545 \\
July 12-16, 1968 & 2,544 & 4,909 & 982 \\
October 19-November 19, 1969 & 1,968 & 5,438 & 170 \\
May 25-June 14, 1970 & 5,543 & 50,447 & 2,402 \\
July 8-18, 1971 & 9,894 & 17,480 & 1,589 \\
August 8-September 6, 1971 & 11,006 & 74,537 & 2,485 \\
September 10-30, 1971 & 14,432 & 53,578 & 2,551 \\
\hline
\end{tabular}

gage, station 08211200 Nueces River at Bluntzer, Tex. (hereinafter, Bluntzer gage), and station 08211500 Nueces River at Calallen, Tex. (hereinafter, Calallen gage) (fig. 2). Whereas the historical suspended-sediment data-collection program typically involved daily sample collection to compute longterm sediment loads, 2006-07 suspended-sediment samples represent data only for selected streamflow and sediment-load conditions. Eight suspended-sediment samples were collected at the Mathis gage, 11 at the Bluntzer gage, and 10 at the Calallen gage.

Using standard USGS protocols and quality-control (QC) procedures (U.S. Geological Survey, 2006), an isokinetic sampler was used to collect suspended-sediment samples in 2006 and 2007. Ockerman and Fernandez (2010, p. 7) noted other investigators' findings that "an isokinetic sampler collects a water-sediment sample from the stream at a rate such that the velocity of the intake nozzle is equal to the incident stream velocity at the nozzle entrance. The water-sediment sample collected is thus representative of the suspendedsediment load throughout the channel cross section and is appropriate for use in estimating sediment load carried by the stream (Davis, 2005)."

Samples were collected at five or more equally spaced intervals across the stream channel and were depth-integrated by lowering and raising the sampler through the water at a constant rate. The samples from each equal-width segment were then combined into a single composite sample for analysis. A composite water-sediment sample is horizontally and vertically averaged throughout the stream cross section and is assumed to represent the average streamflow-weighted suspended-sediment concentration (Edwards and Glysson, 1999; U.S. Geological Survey, 2006).

Suspended-sediment samples were collected by wading when streamflow conditions permitted. During higher flow conditions, when wading was not possible, samples were collected from a bridge or by boat. Suspended-sediment samples collected by the USGS were analyzed by the USGS sediment laboratory in Iowa City, Iowa. Samples were analyzed for suspended-sediment concentration and sand-separation analysis. Sand-separation analysis gives the percentage of sediment, by weight, that is finer and coarser than 0.0625 millimeter. Particle sizes smaller than 0.0625 millimeter are defined as silt and clay; particle sizes 0.0625 millimeter or larger are defined as sand (Guy, 1969).

Each suspended-sediment sample collected by the USGS was associated with a streamflow value. Streamflow data were usually obtained from the stage-discharge rating curve at the streamflow-gaging station where suspended-sediment samples were collected (Rantz and others, 1982). For some high-flow conditions, streamflow measurements were made when the suspended-sediment samples were collected. The availability of streamflow data and suspended-sediment concentration data allowed computation of suspended-sediment discharge, or load, according to equation 1 :

$$
\mathrm{L}_{\mathrm{s}}=\mathrm{Q} \times \mathrm{C}_{\mathrm{s}} \times \mathrm{k}_{\mathrm{s}}
$$


where

$\mathrm{L}_{\mathrm{s}}$ is the instantaneous suspended-sediment load, in tons per day;

$\mathrm{Q}$ is the streamflow, in cubic feet per second;

$\mathrm{C}_{\mathrm{s}}$ is the suspended-sediment concentration, in milligrams per liter; and

$\mathrm{k}_{\mathrm{s}}$ is a conversion factor of 0.0027 , which results in a sediment load in tons per day, given streamflow in cubic feet per second and suspended-sediment concentration in milligrams per liter (Porterfield, 1972, p. 46-47).

\section{Simulation of Streamflow and Suspended-Sediment Concentrations and Loads of the Lower Nueces River}

Although historical suspended-sediment loads during 1942-82 are available for the Nueces River near Mathis (at the Mathis gage), suspended-sediment concentrations and loads downstream from the Mathis gage have not been documented, and suspended-sediment concentrations and loads at the Mathis gage have possibly changed since they were last documented. To better understand suspendedsediment conditions in the lower Nueces River and to estimate the amount of suspended sediment transported to the Nueces Estuary, a watershed model was developed to simulate streamflow and suspended-sediment loads in the lower Nueces River.

Streamflow and suspended-sediment concentrations and loads were simulated with the Hydrological Simulation Program-FORTRAN (HSPF) (Bicknell and others, 2001). HSPF was selected for the study watershed because it is one of the more comprehensive watershed models available, can simulate a variety of stream and watershed conditions with reasonable accuracy, and enables flexibility in adjusting the model to simulate alternative conditions or scenarios (Donigian and others, 1995). To simulate the hydrologic and sediment processes that occur in a watershed, different data sources are used as input to the HSPF model including rainfall data, potential evapotranspiration, and other meteorological parameters; land cover and land use; and soil characteristics. The outputs of an HSPF model are simulated time series of suspended concentrations, sediment loads, or both, as well as streamflow; the time series are for a user-specified interval, or time step. A 1-hour time step was used for this study. HSPF also can simulate other water-quality constituents, including nutrients, metals, and organic compounds. Simulations for this study were limited to streamflow and suspended sediment.

Continuous (hourly) models enable simulation of important watershed processes for a full range of streamflows. Ockerman and Roussel $(2009$, p. 4) noted other investigators' findings that "the relative importance of various processes and factors influencing water quality can vary considerably with the magnitude of streamflow. For example, processes that appreciably affect water-quality conditions during low flows might have relatively minor effects on water-quality conditions during high flows. For assessment of peak-streamflow characteristics, continuous simulation models can provide a more realistic evaluation of antecedent soil-moisture conditions than is generally possible with event-based models (Martin and others, 2001, p. 66)."

\section{Functional Description of Hydrological Simulation Program-FORTRAN ${ }^{1}$}

HSPF, a continuous, semi-lumped parameter model (Singh, 1995), provides continuous water and mass balance by tracking rainfall and water-quality constituents through the conceptual pathways of the hydrologic cycle. In HSPF, a watershed is represented by a group of hydrologically similar areas referred to as hydrologic response units (HRUs) that drain to a stream segment, lake, or reservoir referred to as a RCHRES (ReaCH REServoir). HRUs are areas in a subwatershed that have similar hydrologic and water-quality characteristics that are determined on the basis of land use, surficial geology, soil characteristics, and other factors that are deemed to produce similar hydrologic responses to rainfall and potential evapotranspiration. HRUs are categorized as either pervious or impervious land segments, termed PERLND (PERvious LaND) or IMPLND (IMPervious LaND), respectively. A PERLND is represented conceptually within HSPF by three interconnected water-storage zones-an upper zone, a lower zone, and a groundwater zone. An IMPLND is represented by surface storage, evaporation, and runoff processes. Each RCHRES is associated with a particular subwatershed and receives the runoff, sediment, and chemical loads from the PERLNDs and IMPLNDs in the subwatershed. The hydraulics of a RCHRES are simulated by a storage routing method (Donigian and others, 1995).

HSPF is composed of a series of computational routines that separately simulate processes of the hydrologic cycle. Specifically, HSPF simulates the hydrologic cycle as an interconnected series of storage (and processing) segments with water fluxes (volume per unit area per unit time) and constituent fluxes (mass [weight] per unit area per unit time) moving between the various storages. Figure 4 shows a flowchart of HSPF hydrologic processes for IMPLNDs and PERLNDs. Figure 5 shows a flowchart of HSPF sediment processes for IMPLNDs, PERLNDs, and RCHRESs. The movement of water and suspended sediment from IMPLNDs and PERLNDs and between storage zones is controlled by various processrelated parameters. Although some parameters are directly measurable, most are estimated during model calibration (Martin and others, 2001).

The HSPF model of the lower Nueces River watershed was developed by (1) compiling and processing required input data, (2) configuring the model to represent the watershed, and (3) calibrating the model to improve simulation accuracy.

\footnotetext{
${ }^{1}$ This section modified from Ockerman and Roussel (2009, p. 4-7).
} 

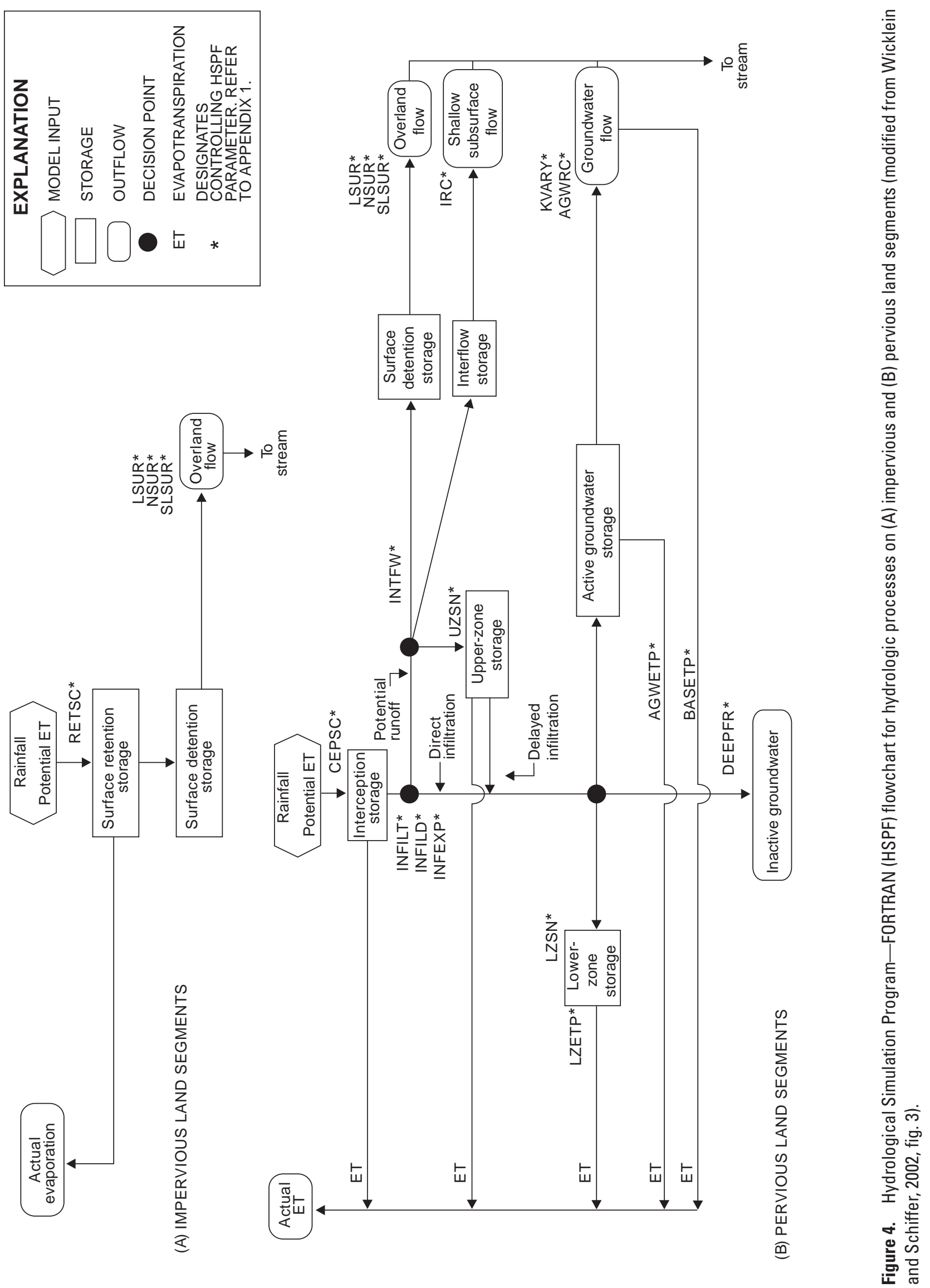

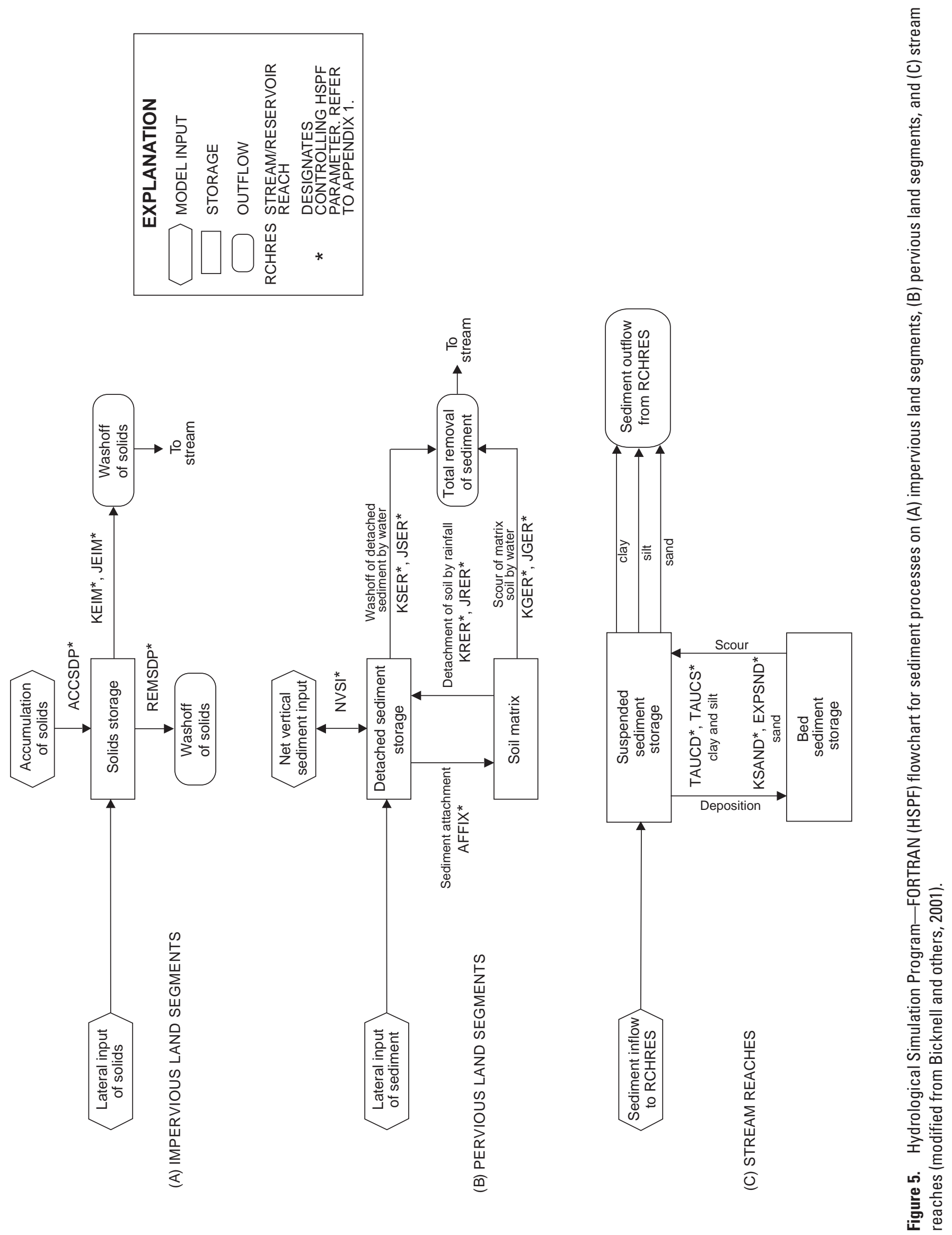
The definitions of the HSPF model process parameters used in the lower Nueces River watershed model are listed in appendix 1. A complete description of the computational processes and required input model parameters is provided in the HSPF users' manual (Bicknell and others, 2001).

\section{Input Data for the Lower Nueces River Watershed Model}

Input data for the lower Nueces River watershed model included spatial data (land cover, geology, soils, topography, and drainage characteristics such as subwatershed boundaries and stream-reach length and cross-section data) and times-series data, including meteorological data (rainfall and potential evapotranspiration), streamflow data, and suspendedsediment concentrations. Spatial data were used to create the model HRUs and RCHRESs. Of all the input data, meteorological data had the most pronounced effect on the results of the time-series simulations. Streamflow and suspendedsediment data were used to calibrate the model.

Land-cover data for the study area were obtained from the U.S. Environmental Protection Agency's Multi-Resolution Land Characteristics Consortium (Homer and others, 2004). In the lower Nueces River watershed, there were 15 land covers and land uses as classified by the 2001 National Land Cover Database (NLCD) (Multi-Resolution Land Characteristics Consortium, 2008). To simplify the model configuration, the 15 classes were reclassified into 7 land-cover categories shown on figure 6. Areas classified as open water were modeled as part of a RCHRES. Developed land use was principally classified as low-intensity development, of which about 15 percent was simulated as impervious area. Barren land was grouped with developed open space and the resulting acreage also was considered to be 15-percent impervious.

Surficial geology data (fig. 7) were obtained from areal geologic maps published in the "Geologic Atlas of Texas" (GAT) by the University of Texas Bureau of Economic Geology for the following areas within the lower Nueces River study area: Beeville-Bay City sheet (Aronow and others, 1975) and Corpus Christi sheet (Aronow and Barnes, 1975). The most upstream parts of the study area include the Pleistoceneage Lissie and Deweyville Formations. Most of the rest of the study area is covered by the Beaumont Formation (Pleistocene age) or alluvium (recent age). In the Lissie and Deweyville Formations, the sediments, in order of dominance, consist mostly of sand, silt, and clay. In the Beaumont Formation and alluvium, the sediments, in order of dominance, consist mostly of clay, silt, and sand (Minzenmayer, 1979). The data obtained from the Beeville-Bay City sheet (northern part of the study area) provide a more detailed breakdown of the areas of the Beaumont Formation that are dominated by clay or sand, compared with the data available from the Corpus Christi sheet (southern part of the study area).

Soils data for the study area were compiled from the U.S. Department of Agriculture, Natural Resources Conservation
Service (2009) "Soil Survey Geographic (SSURGO) Database." These data were used to provide initial estimates for selected HSPF process-related parameter values, primarily soil infiltration rate (INFILT). Figure 8 shows the relative soil infiltration rates for the study area.

Topography (slope) data for the study area were obtained from USGS 7.5-minute digital elevation models (U.S. Geological Survey, 2001). The digital elevation models also were used to delineate subwatersheds as part of the HSPF model development. The study area was subdivided into 64 subwatersheds as shown on figure 9. The average size of each subwatershed is 2,000 acres. Also shown on figure 9 is the stream network used in the model configuration. The stream segment (RCHRES) that is associated with each subwatershed is identified with the same identification number as the subwatershed identification number shown in figure 9. Spatial data for streams (location and reach length) were obtained from the "National Hydrography Dataset" (U.S. Geological Survey, 2009). Stream-channel cross-section data were obtained from streamflow discharge measurements made at USGS streamflow-gaging stations in the study area (U.S. Geological Survey, 2010).

Streamflow data from the Mathis gage were used as a boundary condition input to the model. Location information, type of data collected, and period of record for sites that provided streamflow data for the lower Nueces River watershed are listed in table 3. Locations of the streamflow-gaging stations are shown on figure 10.

Water is withdrawn from the Nueces River for municipal and industrial uses in RCHRES 82 and 84 (fig. 9). These withdrawals averaged 64,500 acre-feet per year or the flow volume equivalent to a continuous flow of about 89 cubic feet per second during 2000-2008 (Nueces River Authority, 2009); withdrawal data are available as monthly totals. Within HSPF, the monthly total withdrawals were disaggregated to hourly values and input to the model.

Rainfall and air temperature data were obtained from NWS stations Mathis, Mathis 4 SSW, Robstown, Robstown Airport (rainfall only), Corpus Christi International Airport, and Corpus Christi Maus Field (sites 1-6, respectively, fig. 10; table 3). The NWS has operated rainfall stations in Mathis and Robstown since 1957 and 1947, respectively. The Mathis 4 SSW station replaced the Mathis station in 1977. The Robstown station has been in operation since 1947 and the Robstown Airport station since 2003. The Mathis and Mathis 4 SSW stations (sites 1 and 2, respectively, fig. 10; table 3) and the Robstown and Robstown Airport stations (sites 3 and 4, respectively, fig. 10; table 3) were the primary sources of rainfall data. For modeling purposes, the data from the two Mathis stations were combined and the location of the rainfall data time series was considered to be the same as the newer Mathis 4 SSW station. Similarly, data from the two Robstown stations were combined into a single time series that was considered to be located at the newer Robstown Airport station. These time series and associated locations were then used for the entire simulation period. The spatial 


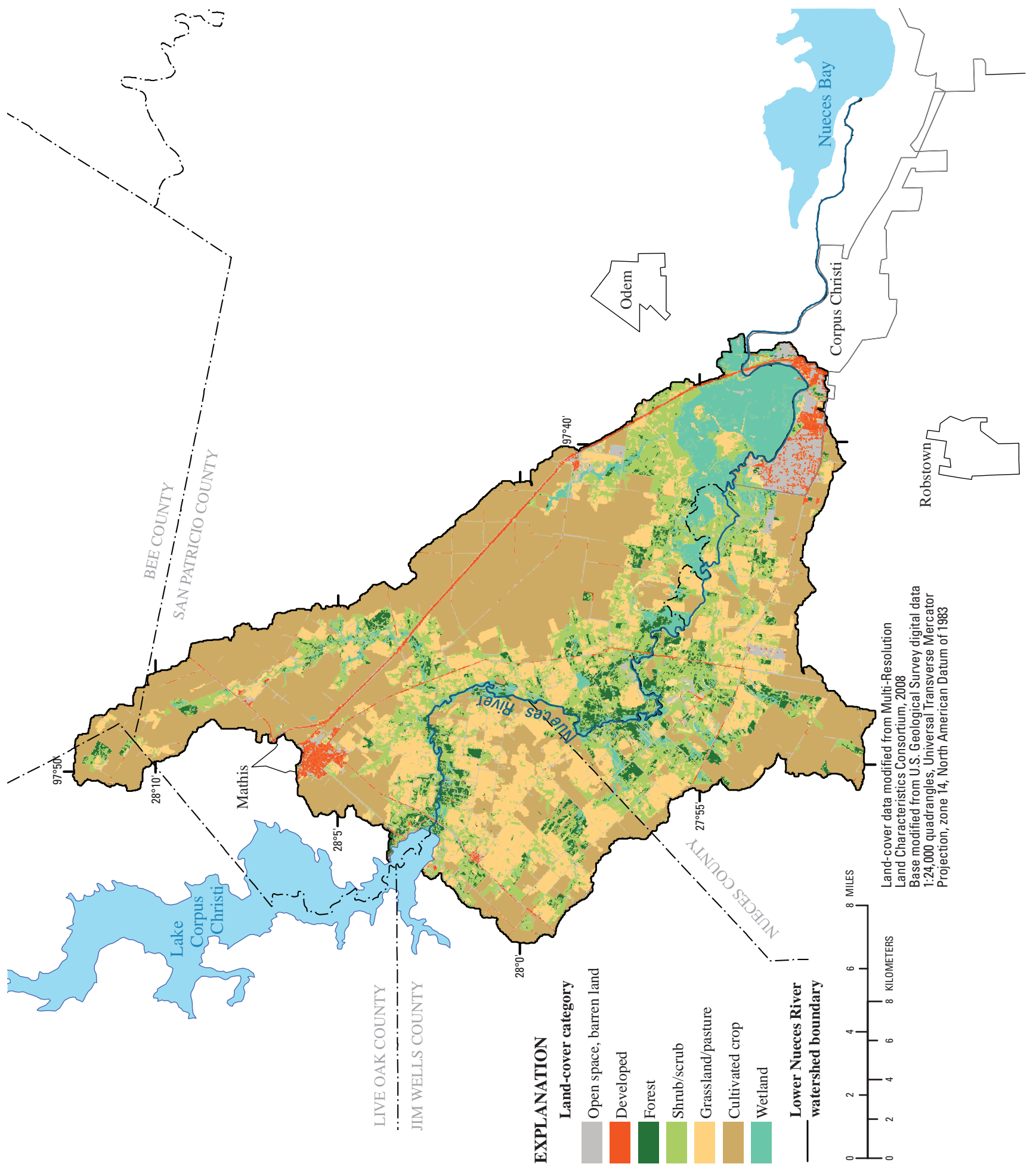

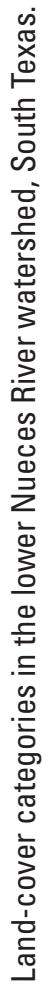




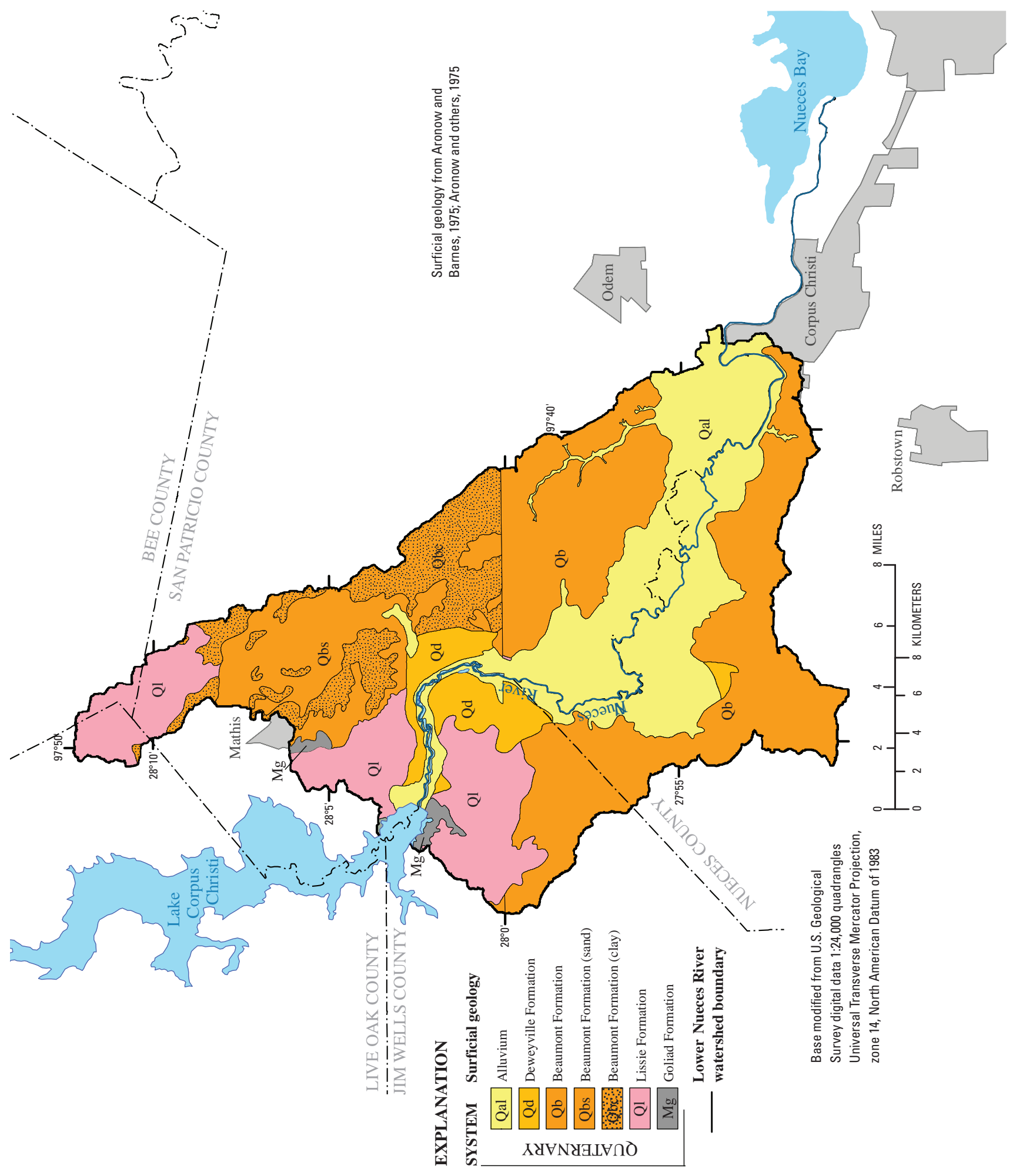

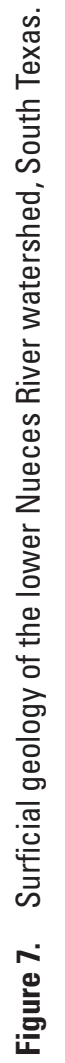




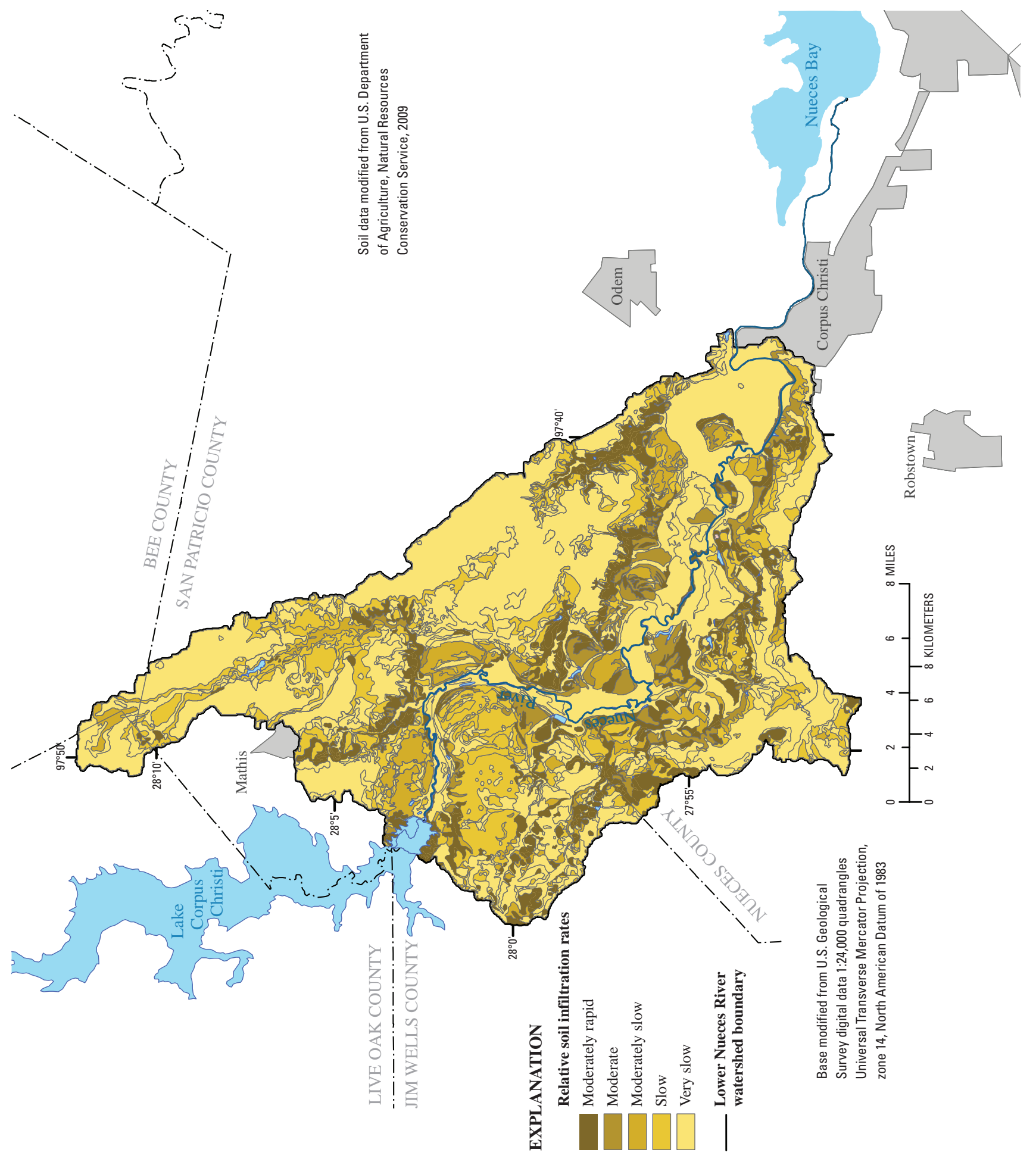




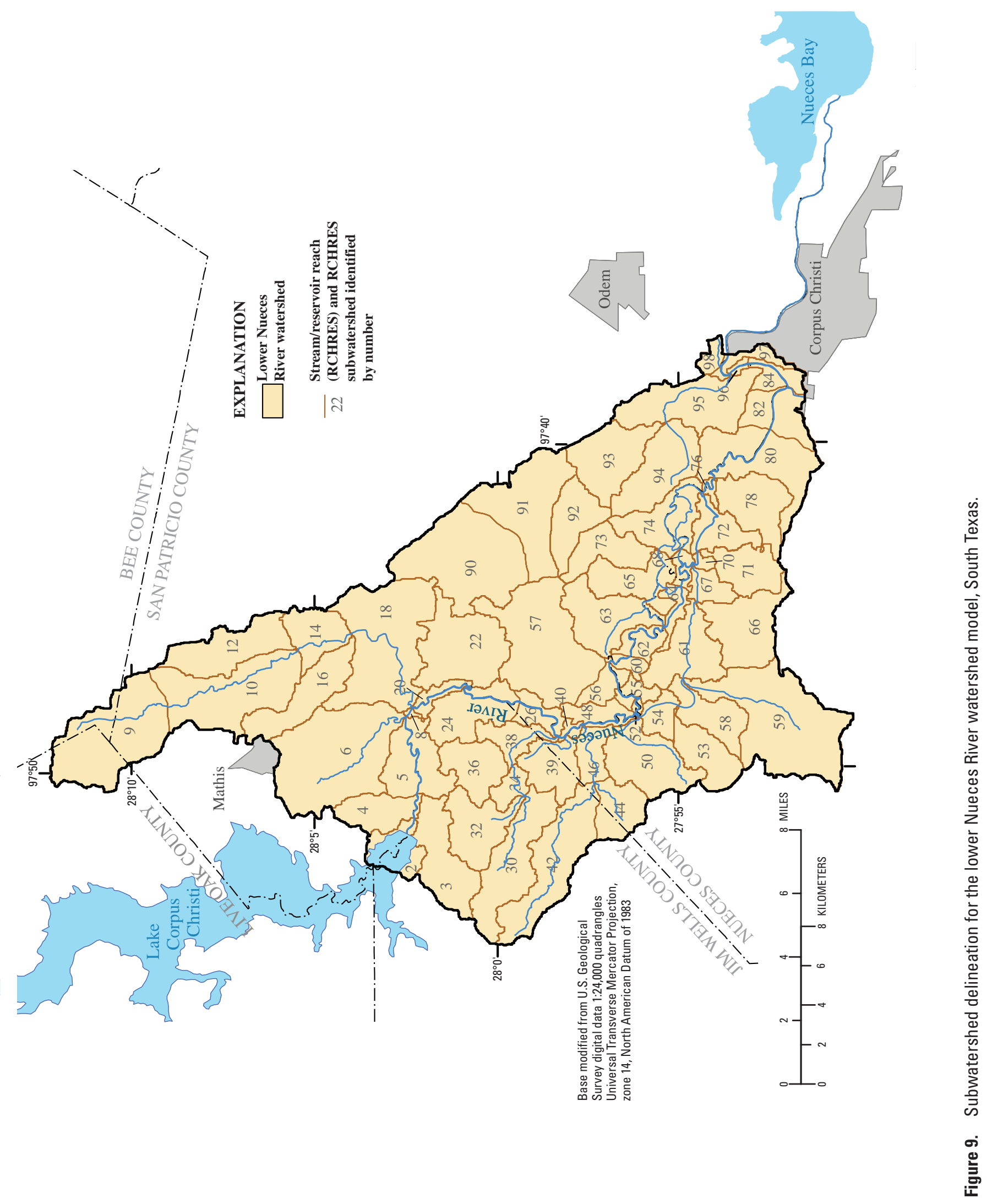




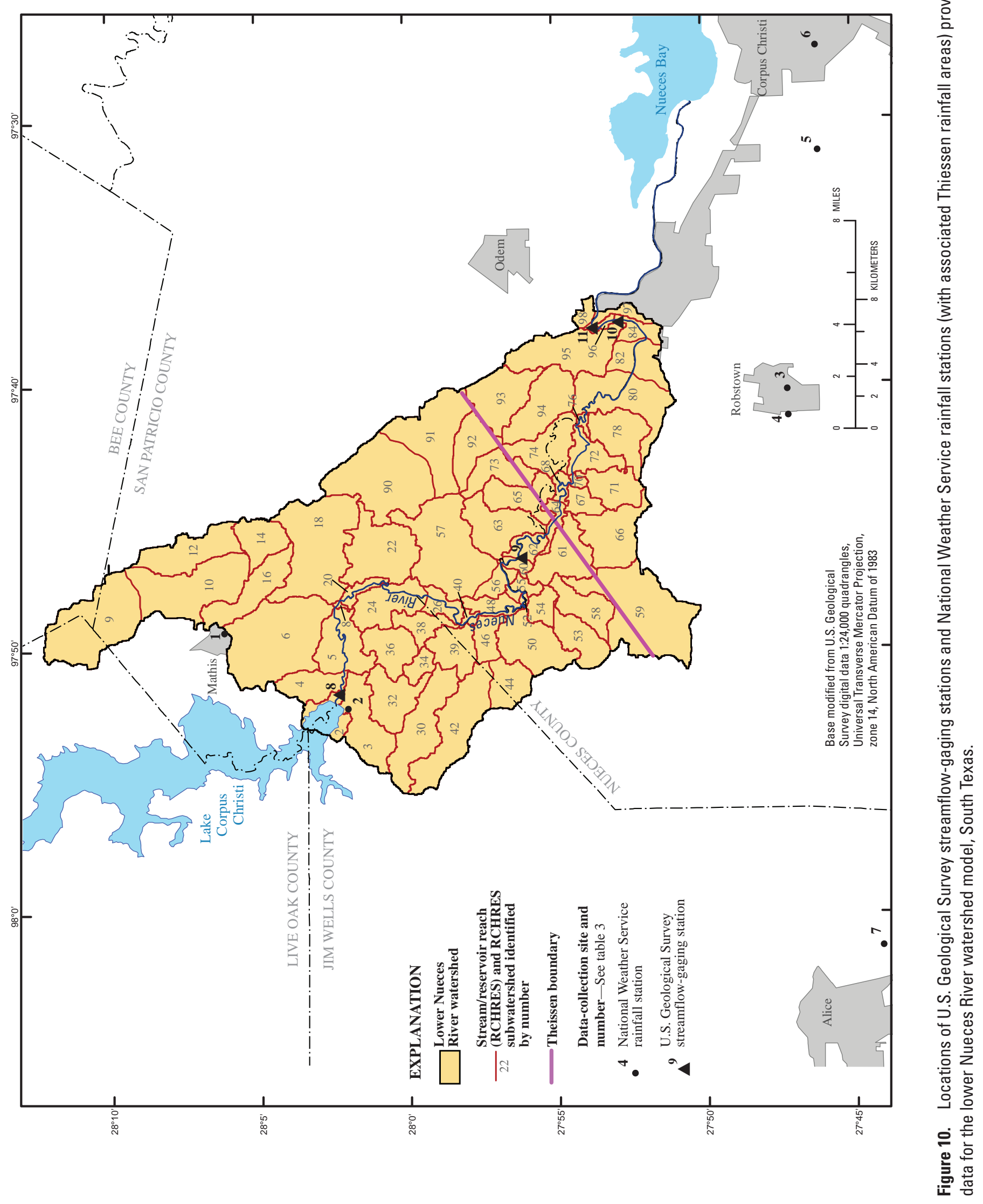


Table 3. Data-collection sites providing data for the lower Nueces River watershed model, South Texas.

[ddmmss, degrees minutes seconds; NWS, National Weather Service; ID, identifier; --, not available; max, maximum; min, minimum; temp, temperature; USGS, U.S. Geological Survey]

\begin{tabular}{|c|c|c|c|c|}
\hline $\begin{array}{c}\text { Site } \\
\text { number } \\
\text { (fig. 10) }\end{array}$ & Station number and name & $\begin{array}{l}\text { Latitude } \\
\text { (ddmmss) }\end{array}$ & $\begin{array}{l}\text { Longitude } \\
\text { (ddmmss) }\end{array}$ & $\begin{array}{c}\text { Type of data } \\
\text { (period of record available) }\end{array}$ \\
\hline 1 & $\begin{array}{l}\text { NWS station Coop ID 415661, Mathis, Jim Wells } \\
\text { County, Tex. }\end{array}$ & $28^{\circ} 06^{\prime}--"$ & $97^{\circ} 49^{\prime}--"$ & $\begin{array}{l}\text { Daily rainfall; daily max and min air temp } \\
\quad(1957-77)\end{array}$ \\
\hline 2 & $\begin{array}{l}\text { NWS station Coop ID 415661, Mathis } 4 \text { SSW, Jim } \\
\text { Wells County, Tex. }\end{array}$ & $28^{\circ} 02^{\prime} 14^{\prime \prime}$ & $97^{\circ} 52^{\prime} 21^{\prime \prime}$ & $\begin{array}{l}\text { Daily rainfall; daily max and min air temp } \\
\quad(1977-2008)\end{array}$ \\
\hline 4 & $\begin{array}{l}\text { NWS station WBAN ID 12984, Robstown Airport, } \\
\text { Nueces County, Tex. }\end{array}$ & $27^{\circ} 46^{\prime} 43^{\prime \prime}$ & $97^{\circ} 41^{\prime} 26^{\prime \prime}$ & Hourly rainfall (2003-08) \\
\hline 5 & $\begin{array}{l}\text { NWS station Coop ID 412015, Corpus Christi Interna- } \\
\text { tional Airport, Nueces County, Tex. }\end{array}$ & $27^{\circ} 46^{\prime} 27^{\prime \prime}$ & $97^{\circ} 30^{\prime} 44^{\prime \prime}$ & $\begin{array}{l}\text { Daily rainfall; daily max and min air temp } \\
\quad(1960-2008)\end{array}$ \\
\hline 6 & $\begin{array}{l}\text { NWS station Coop ID 412015, Corpus Christi Maus } \\
\text { Field, Nueces County, Tex. }\end{array}$ & $27^{\circ} 46^{\prime}--"$ & $97^{\circ} 27^{\prime}--"$ & $\begin{array}{l}\text { Daily rainfall; daily max and min air temp } \\
\quad(1934-60)\end{array}$ \\
\hline 9 & $\begin{array}{l}\text { USGS streamflow-gaging station } 08211200 \text { Nueces } \\
\text { River at Bluntzer, Tex. (partial-record station) }\end{array}$ & $27^{\circ} 56^{\prime} 15^{\prime \prime}$ & $97^{\circ} 46^{\prime} 32^{\prime \prime}$ & $\begin{array}{l}\text { Streamflow (2005-08); suspended sediment } \\
\quad(2006-08)\end{array}$ \\
\hline 10 & $\begin{array}{l}\text { USGS streamflow-gaging station } 08211500 \text { Nueces } \\
\text { River at Calallen, Tex. }\end{array}$ & $27^{\circ} 52^{\prime} 58^{\prime \prime}$ & $97^{\circ} 37^{\prime} 30^{\prime \prime}$ & $\begin{array}{l}\text { Streamflow (2001-08); suspended sediment } \\
\quad(2006-08)\end{array}$ \\
\hline 11 & $\begin{array}{l}\text { USGS streamflow-gaging station } 08211502 \text { Nueces } \\
\text { River near Odem, Tex. (partial-record station) }\end{array}$ & $27^{\circ} 53^{\prime} 42^{\prime \prime}$ & $97^{\circ} 37^{\prime} 43^{\prime \prime}$ & $\begin{array}{l}\text { Streamflow (flood discharge measurements, } \\
\text { 2001-08) }\end{array}$ \\
\hline
\end{tabular}

application of rainfall time-series data to the model is based on a Theissen polygon distribution (Linsley and others, 1982). Two rainfall areas were defined by the Theissen analysis as shown on figure 10. Rainfall to the upstream area of the watershed was simulated using the Mathis station data, and rainfall to the downstream area of the watershed was simulated using the Robstown station data. Rainfall data from the Corpus Christi International Airport, Corpus Christi Maus Field, and Alice stations (sites 5, 6, and 7, respectively, fig. 10; table 3) were used to fill periods of missing data when data from the Mathis or Robstown stations were not available.

HSPF uses time series of potential evapotranspiration (PEVT) data to set the upper limit of actual evapotranspiration (ET) that can be simulated for any of the HRUs. PEVT is the observed ET if there is an unlimited supply of water to satisfy the potential ET rate. PEVT was computed from maximum and minimum daily air temperature (from NWS station data) using the Hamon method (Bidlake, 2002). Similar to the sources of rainfall data, the primary sources of air temperature data were the Mathis and Robstown NWS stations. PEVT time-series data were applied to delineated subwatersheds according to the Theissen boundary shown on figure 10 .

\section{Model Development}

To develop the model, the stream network of the lower Nueces River watershed was segmented into subwatersheds (fig. 9), generally on the basis of (1) similar streamflow travel times that approximated the model time step (1 hour); (2) homogeneous channel properties such as slope and conveyance; and (3) outlets of subwatersheds at points of interest such as streamflow-gaging stations, major tributary confluences, and points of water withdrawals.

In each subwatershed, unique pervious and impervious HRUs were defined according to three factors: (1) land cover and land use; (2) surficial geology and soil characteristics; and (3) the location of the nearest rainfall station (to spatially distribute meteorological input data [rainfall and PEVT]). Spatial information describing these three factors were compiled and analyzed using the Geographic Information System software ArcGIS (ESRI, 2009) to compute the acreage of each HRU within a given subwatershed.

\section{Model Calibration}

A primary goal of model calibration is to adjust the process-related parameter values to minimize the differences 
between measured and simulated flows at a streamflow-gaging station. The model was calibrated in accordance with guidelines by Donigian and others (1984) and Lumb and others (1994). The calibration of the model proceeded in two steps. First, parameters related to hydrologic processes were calibrated. Second, parameters related to suspended-sediment processes were calibrated. Calibration of hydrologic processes included adjusting appropriate model parameters to minimize differences between measured and simulated streamflow at streamflow-gaging stations during 2001-08 over a wide range of hydrologic conditions. Model parameters that control landsurface erosion and washoff processes and instream sediment transport processes were adjusted to minimize differences between measured and simulated suspended-sediment concentrations and loads.

\section{Hydrology}

To evaluate the goodness-of-fit between measured and simulated streamflows, criteria such as error in total streamflow volume for the calibration period and low-flow and highflow distribution were used. Simulation errors were evaluated by comparing total streamflow volume, 50-percent lowest daily flows, and 10-percent highest daily flows. Donigian and others (1984) presented general guidelines for characterizing the goodness-of-fit of HSPF calibrations. For annual and monthly streamflow volumes, model calibration is considered very good when the error is less than 10 percent, good when the error is $10-15$ percent, and fair when the error is $15-25$ percent.

Additionally, model-fit statistics generated by the software program GenScn (GENeration and analysis of model simulation SCeNarios for watersheds) (Kittle and others, 1998) were used to examine the quality of the model fit on an annual, monthly, daily, and hourly basis for the (1) coefficient of determination (R-squared $\left[\mathrm{R}^{2}\right]$ ) of the linear regression between measured and simulated streamflow (Ott and Longnecker, 2001); (2) Nash-Sutcliffe coefficient of modelfit efficiency (NSE) (Nash and Sutcliffe, 1970); (3) mean absolute error (MAE) (StatSoft, Inc., 2010); and (4) root mean square error (RMSE) (StatSoft, Inc., 2010). The $\mathrm{R}^{2}$ and NSE are similar because each provides a measure of the variation in the measured values that is explained by the simulated values. The NSE, however, provides a generally preferable evaluation of the fit quality compared with the $\mathrm{R}^{2}$ because the NSE measures the magnitude of the differences between measured and simulated values, whereas the $\mathrm{R}^{2}$ measures the difference between mean values (Zarriello and Ries, 2000, p. 44). MAE and RMSE express the difference between measured and simulated streamflow in original units (cubic feet per second) (StatSoft, Inc., 2010).

At selected calibration sites, depending on the availability of streamflow data, the calibration process included a separate, post-calibration test of the model fit. For sites where the testing process was performed, some of the observed streamflow-gaging data were withheld from the calibration. After calibration, the withheld data were then used for testing the model fit between measured and simulated streamflow.

Most of the streamflow in the study area originated as releases from Lake Corpus Christi (fig. 1). The Mathis gage is located immediately downstream from the lake and monitors stream discharge from the lake. Daily discharges for this station were available beginning in 1939 and were input to the model at the inlet of RCHRES 4 (fig. 9) as a boundary condition. Because actual gaged streamflow data were used as input to the model at this site, no model calibration was necessary at this station.

The Bluntzer gage (outlet of RCHRES 60, fig. 9) is operated as a partial-record station. Streamflows of more than 2,750 cubic feet per second are not measured because streamflow-gaging conditions are not favorable at higher flows. Because streamflow data from the Bluntzer gage were not suitable for calibration of the entire range of streamflow conditions, calibration of hydrologic parameters upstream from the Bluntzer gage was not based on data from this gage. During 2005-06, streamflow at the Bluntzer gage did not exceed 2,750 cubic feet per second and the 2005-06 data were used as a test of the calibrated model. Streamflow testing results for the Bluntzer gage during 2005-06 (fig. 11; table 4) indicate very good agreement between measured and simulated streamflow volumes; the error in total simulated streamflow volume compared with measured streamflow volume during 2005-06 at this gage was less than 2 percent.

The Calallen gage was operated as a partial-record station during 1989-2000; daily streamflows were not reported when instantaneous streamflow exceeded 2,750 cubic feet per second because of difficulty measuring higher streamflows at this gage. A complete record of streamflow for the Calallen gage is available for 2001-08. In June 2000, the Calallen gage was moved about 0.4 mile downstream to its present location and converted to a continuous streamflow-gaging station capable of measuring the full range of streamflow. Streamflow data measured during 2005-08 at the Calallen gage were used to calibrate the model and streamflow data from 2001-04 were used to test the calibrated model. Streamflow calibration and testing results for the Calallen gage (fig. 12; table 4) indicate very good agreement between measured and simulated streamflow volumes. The error in total simulated streamflow volume at the Calallen gage compared with measured streamflow volume during the calibration period (2005-08) is less than 3 percent; for the testing period (2001-04), the error in total simulated streamflow volume compared with measured streamflow volume is less than 6 percent.

Using evaluation criteria by Donigian and others (1984), calibration and testing results for streamflow volumes at both the Bluntzer (testing only) and Calallen gages (table 4) were considered very good. The $\mathrm{R}^{2}$ and NSE values were considered acceptable for annual, monthly, daily, and hourly statistics. The NSE for hourly streamflows ranged from .90 to .96 for the calibration and testing periods at the Bluntzer and Calallen gages. The minimum NSE values for daily, monthly, 

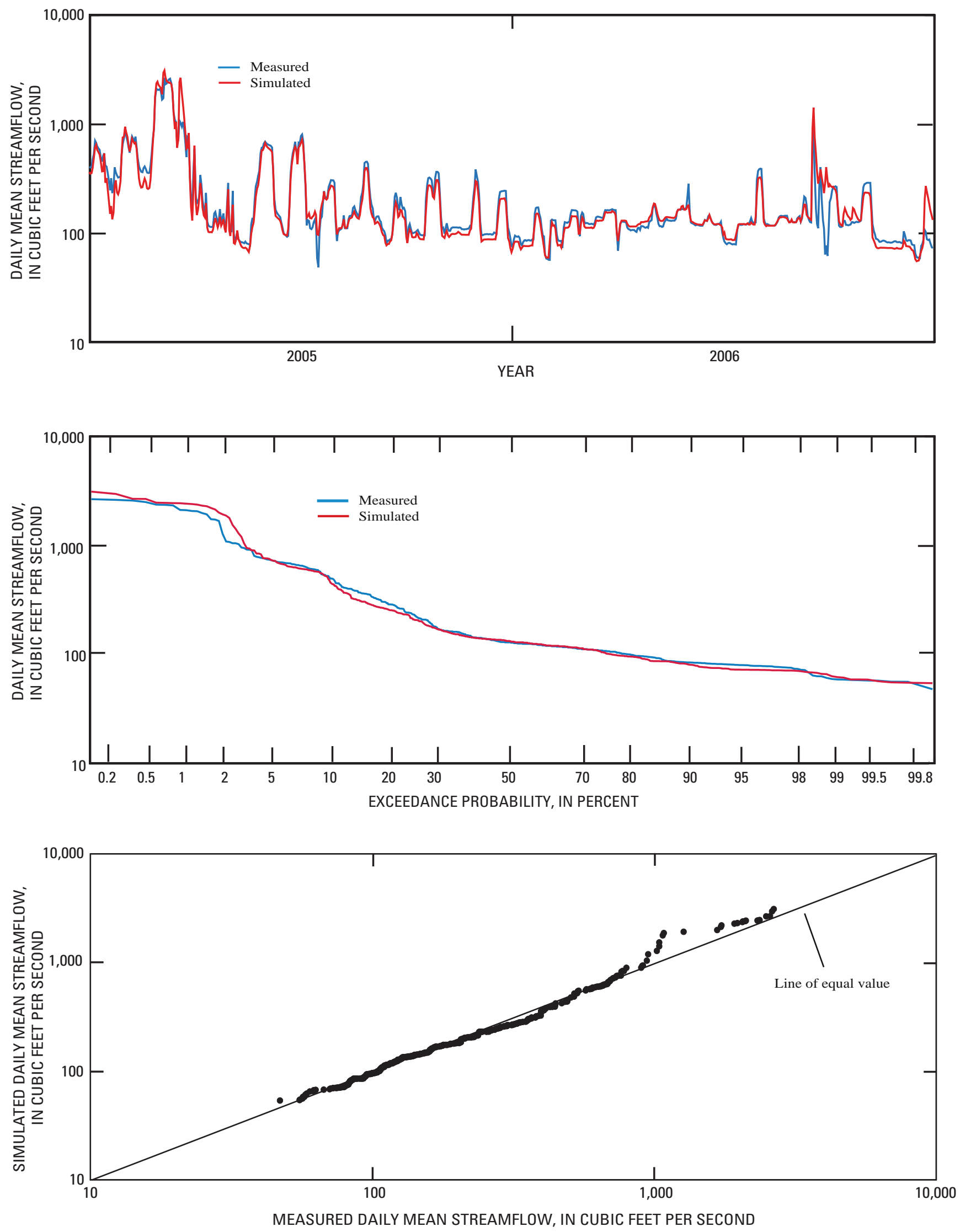

Figure 11. Measured and simulated daily mean streamflow at U.S. Geological Survey streamflow-gaging station 08211200 Nueces River at Bluntzer, Texas, 2005-06. 

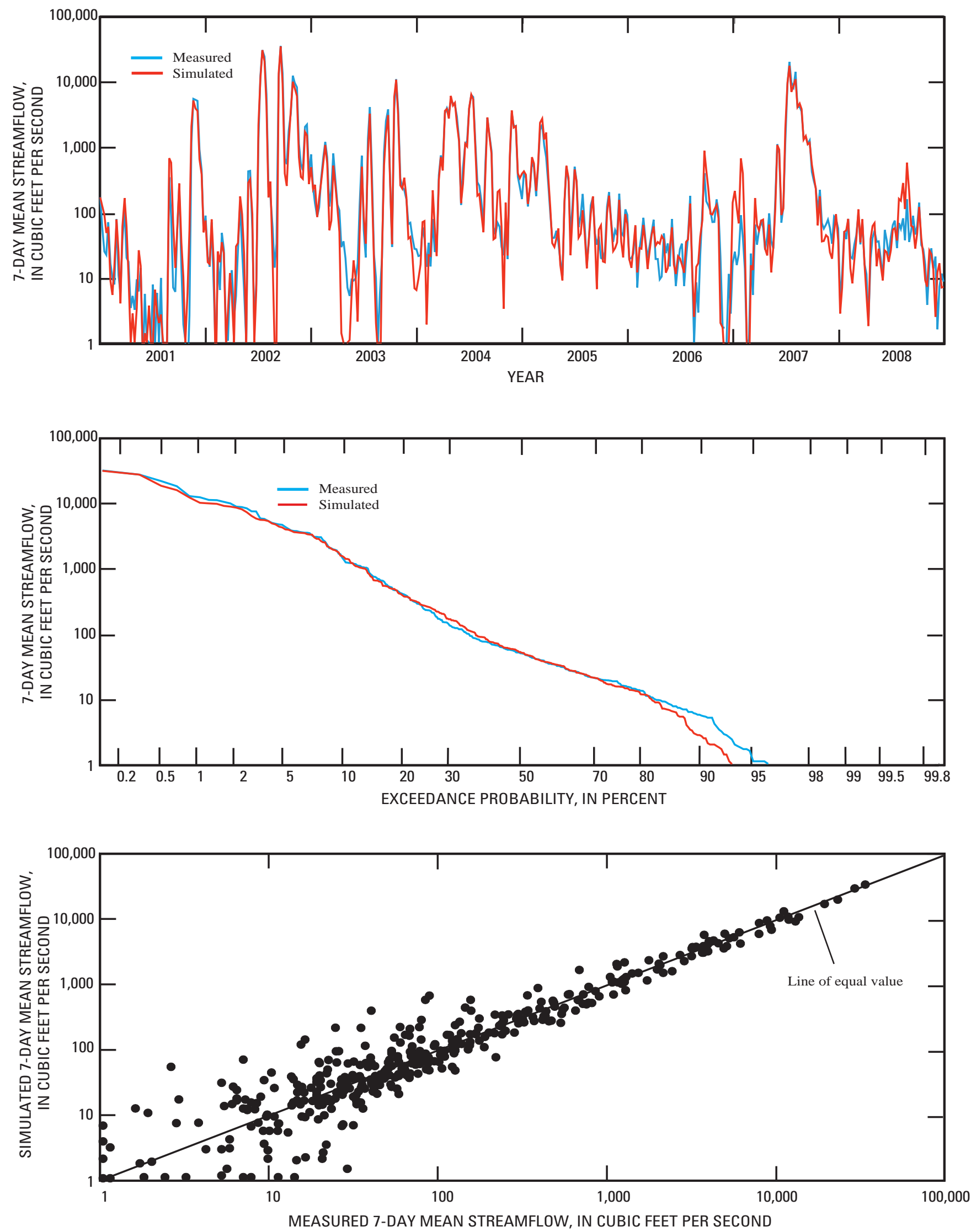

Figure 12. Measured and simulated 7-day mean streamflow at U.S. Geological Survey streamflow-gaging station 08211500 Nueces River at Calallen, Texas, 2001-08. 
Table 4. Streamflow calibration and testing results for the lower Nueces River watershed model, South Texas.

[acre-ft, acre-feet; $\mathrm{ft}^{3} \mathrm{~s}$, cubic feet per second]

08211200 Nueces River at Bluntzer, Texas

Testing period 2005-06

\begin{tabular}{|c|c|c|c|c|}
\hline Streamflow volumes and peaks & Measured & Simulated & $\begin{array}{c}\text { Error } \\
\text { (percent) }\end{array}$ & $\begin{array}{c}\text { Criteria } \\
\text { (percent) }\end{array}$ \\
\hline Total flow volume (acre-ft) & 353,000 & 357,000 & 1.1 & 10 \\
\hline Mean flow rate $\left(\mathrm{ft}^{3} / \mathrm{s}\right)$ & 244 & 247 & 1.1 & 10 \\
\hline Highest 10-percent daily flows (acre-ft) & 151,000 & 166,000 & 9.9 & 10 \\
\hline Lowest 50-percent daily flows (acre-ft) & 72,800 & 71,600 & -1.6 & 10 \\
\hline Model-fit statistics 2005-06 & Annual & Monthly & Daily & Hourly \\
\hline Number of years, months, days, or hours & 2 & 24 & 730 & 17,520 \\
\hline Coefficient of determination $\left(\mathrm{R}^{2}\right)$ & 1.00 & .98 & .92 & .91 \\
\hline Nash-Sutcliffe coefficient of model-fit efficiency (NSE) & 1.00 & .97 & .91 & .90 \\
\hline Mean absolute error $\left(\mathrm{ft}^{3} / \mathrm{s}\right)$ & 4.5 & 30.7 & 38.4 & 38.4 \\
\hline Root mean square error $\left(\mathrm{ft}^{3} / \mathrm{s}\right)$ & 5.3 & 57.0 & 117 & 124 \\
\hline
\end{tabular}

08211500 Nueces River at Calallen, Texas

Calibration period 2005-08

\begin{tabular}{|c|c|c|c|c|}
\hline Streamflow volumes and peaks & Measured & Simulated & $\begin{array}{c}\text { Error } \\
\text { (percent) }\end{array}$ & $\begin{array}{c}\text { Criteria } \\
\text { (percent) }\end{array}$ \\
\hline Total flow volume (acre-ft) & $1,400,000$ & $1,440,000$ & 2.9 & 10 \\
\hline Mean flow rate $\left(\mathrm{ft}^{3} / \mathrm{s}\right)$ & 483 & 497 & 2.9 & 10 \\
\hline Highest 10-percent daily flows (acre-ft) & $1,220,000$ & $1,215,000$ & -.4 & 10 \\
\hline Lowest 50-percent daily flows (acre-ft) & 25,400 & 25,100 & -1.2 & 10 \\
\hline Model-fit statistics 2005-08 & Annual & Monthly & Daily & Hourly \\
\hline Number of years, months, days, or hours & 4 & 48 & 1,461 & 35,064 \\
\hline Coefficient of determination $\left(\mathrm{R}^{2}\right)$ & 1.00 & 1.00 & .95 & .95 \\
\hline Nash-Sutcliffe coefficient of model-fit efficiency (NSE) & 1.00 & .99 & .93 & .92 \\
\hline Mean absolute error $\left(\mathrm{ft}^{3} / \mathrm{s}\right)$ & 37 & 66 & 127 & 130 \\
\hline Root mean square error $\left(\mathrm{ft}^{3} / \mathrm{s}\right)$ & 39 & 152 & 510 & 523 \\
\hline
\end{tabular}

and annual simulations for both stations were $.91, .97$, and .98 , respectively (table 4).

\section{Suspended Sediment}

Suspended-sediment concentrations and loads were simulated using the appropriate HSPF modules: SEDMNT for PERLND simulation, SOLIDS for IMPLND simulation, and SEDTRN for RCHRES simulation. For each PERLND, the processes of detachment of sediment from the soil matrix and washoff of this sediment were simulated on the basis of rainfall intensity, surface runoff, and model parameters that control the accumulation, detachment, and transport of soils. For each IMPLND, the processes of accumulation and washoff of sediment were simulated in the SOLIDS module. In each RCHRES, the sediment-transport processes in the stream channel were simulated by the SEDTRN module. Transport processes in RCHRES included deposition and scour, which are functions of sediment size, settling velocity, density, erodibility, bed depth, and critical shear stress. RCHRES sediment transport is computed separately for each sand, silt, and clay fraction of sediment size. 
Table 4. Streamflow calibration and testing results for the lower Nueces River watershed model, South Texas-Continued.

08211500 Nueces River at Calallen, Texas

Testing period 2001-04

\begin{tabular}{|c|c|c|c|c|}
\hline Streamflow volumes and peaks & Measured & Simulated & $\begin{array}{c}\text { Error } \\
\text { (percent) }\end{array}$ & $\begin{array}{c}\text { Criteria } \\
\text { (percent) }^{2}\end{array}$ \\
\hline Total flow volume (acre-ft) & $4,225,000$ & $4,007,000$ & -5.2 & 10 \\
\hline Mean flow rate $\left(\mathrm{ft}^{3} / \mathrm{s}\right)$ & 1,455 & 1,380 & -5.2 & 10 \\
\hline Highest 10-percent daily flows (acre-ft) & $3,167,000$ & $3,066,000$ & -3.2 & 10 \\
\hline Lowest 50-percent daily flows (acre-ft) & 21,500 & 23,500 & 9.3 & 10 \\
\hline Model-fit statistics 2001-04 & Annual & Monthly & Daily & Hourly \\
\hline Number of years, months, days, or hours & 4 & 48 & 1,461 & 35,064 \\
\hline Coefficient of determination $\left(\mathrm{R}^{2}\right)$ & 1.00 & 1.00 & .96 & .96 \\
\hline Nash-Sutcliffe coefficient of model-fit efficiency (NSE) & .98 & .99 & .96 & .96 \\
\hline Mean absolute error $\left(\mathrm{ft}^{3} / \mathrm{s}\right)$ & 83 & 130 & 307 & 314 \\
\hline Root mean square error $\left(\mathrm{ft}^{3} / \mathrm{s}\right)$ & 133 & 265 & 838 & 862 \\
\hline
\end{tabular}

08211500 Nueces River at Calallen, Texas

Simulation period 2001-08

\begin{tabular}{|c|c|c|c|c|}
\hline Streamflow volumes and peaks & Measured & Simulated & $\begin{array}{c}\text { Error } \\
\text { (percent) }{ }^{1}\end{array}$ & $\begin{array}{c}\text { Criteria } \\
\text { (percent) })^{2}\end{array}$ \\
\hline Total flow volume (acre-ft) & $5,613,000$ & $5,422,000$ & -3.4 & 10 \\
\hline Mean flow rate $\left(\mathrm{ft}^{3} / \mathrm{s}\right)$ & 970 & 937 & -3.4 & 10 \\
\hline Highest 10-percent daily flows (acre-ft) & $4,720,000$ & $4,507,000$ & -4.5 & 10 \\
\hline Lowest 50-percent daily flows (acre-ft) & 46,000 & 46,200 & 0.4 & 10 \\
\hline Model-fit statistics 2001-08 & Annual & Monthly & Daily & Hourly \\
\hline Number of years, months, days, or hours & 8 & 96 & 2,922 & 70,128 \\
\hline Coefficient of determination $\left(\mathrm{R}^{2}\right)$ & 1.00 & 1.00 & .96 & .96 \\
\hline Nash-Sutcliffe coefficient of model-fit efficiency (NSE) & .99 & .99 & .96 & .96 \\
\hline Mean absolute error $\left(\mathrm{ft}^{3} / \mathrm{s}\right)$ & 60 & 98 & 217 & 222 \\
\hline Root mean square error $\left(\mathrm{ft}^{3} / \mathrm{s}\right)$ & 98 & 216 & 694 & 713 \\
\hline
\end{tabular}

${ }^{1}$ Error $=[($ simulated-measured $) /$ measured $] \times 100$.

${ }^{2}$ Default error criteria from HSPEXP (Lumb and others, 1994).

Selection of initial values and calibration of sedimentrelated process parameters of the SEDMNT, SOLIDS, and SEDTRN modules (appendix 1) were based on published guidelines (Donigian and Love, 2003; U.S. Environmental Protection Agency, 2006). Calibration of sediment-related parameters involved the following steps: (1) Estimation of suspended-sediment loads carried in flows released from Lake Corpus Christi; (2) identification of reasonable sediment yields from the various land types in the watershed; (3) estimation of the soil-erosion and sediment-washoff parameters used to generate sediment washoff from PERLNDs and IMPLNDs, respectively; and (4) calibration of sedimenttransport (RCHRES) parameters by comparison of measured and simulated suspended-sediment concentrations and loads at the streamflow-gaging stations.

\section{Estimation of Suspended-Sediment Loads from Lake} Corpus Christi

Estimation of suspended-sediment loads in releases from Lake Corpus Christi were based on 14 reported suspended-sediment loads during 1964-71 (table 2) and 
8 suspended-sediment samples collected by the USGS during 2006-07 (table 5). All suspended-sediment data (historical and recent) were collected at the Mathis gage downstream from Lake Corpus Christi. These data represented streamflow ranging from 72 to 35,129 cubic feet per second and suspendedsediment loading rates ranging from 4.3 to 8,872 tons per day. Data collected during 1964-71 represented mean streamflow and suspended-sediment loads during relatively large releases that lasted days or weeks. Data collected during 2006-07 represented instantaneous conditions (a typical suspendedsediment sample was collected during a period of about 1 hour). A least-squares regression equation (fig. 13) was developed relating daily mean discharge at the Mathis gage and daily sediment load. Discharge and sediment load were log-transformed before performing the regression to improve the quality of the regression fit, then retransformed to original units (Helsel and Hirsch, 2002). The resulting equation was

$$
\mathrm{L}=0.026 \times \mathrm{Q}^{1.195},
$$

where

$\mathrm{L}=$ suspended-sediment load, in tons per day; and

$\mathrm{Q}=$ daily mean discharge, in cubic feet per second.

The $\mathrm{R}^{2}$ for the regression equation was .94; the standard error of the residuals (RSE), a measure of the dispersion of the data around the regression line (Helsel and Hirsch, 2002, p. 244) was 121 pounds per day. The residual plot on figure 13 shows the regression residuals (as a percentage of the measured suspended-sediment load) plotted as a function of the measured suspended-sediment load. The distribution of the error residuals was relatively uniform, indicating a reasonable regression model.

A comparison of model-simulated input of suspendedsediment loads with suspended-sediment loads computed from eight samples collected at the Mathis gage during 200607 is listed in table 5 . These results are not considered a calibration but rather a test of the ability of the model (equation 2) to reasonably simulate instantaneous suspended-sediment concentrations and loads entering the study area through releases from Lake Corpus Christi. In general, measured and simulated suspended-sediment loads compare favorably. Regression-equation derived sediment loads were within 30 percent of measured loads for all samples except that on November 20, 2006, for which the simulated load was 116 percent of the measured load (table 5). The November 20, 2006, sample was collected during a period of low flow and represented a relatively small sediment load, compared with the relatively high flows that were mostly sampled at this site. Therefore, the loads computed by the regression equation were considered reasonable estimates of the total suspendedsediment loads that were discharged from Lake Corpus Christi.

The time series of sediment loads from Lake Corpus Christi were apportioned between clay and silt particle sizes and input to the model in RCHRES 4 (as was done with flows from Lake Corpus Christi). An apportionment of 40 percent silt and 60 percent clay was done on the basis of literature synthesis work by White and Calnan (1990).

\section{Sediment Yields for Selected Land-Use Types and Land Covers}

Several studies of sediment yields (pounds per acre or tons per acre) from specific land-use types and land covers have been made for the South Texas area (Baird and others, 1996; Ockerman and Petri, 2001; Ockerman, 2002; Ockerman and Fernandez, 2010). These studies provided data for sediment yields for cropland, rangeland (pasture/grassland), and developed land. Data and analyses from these studies were compared with simulated sediment yields from similar land type PERLNDs. Sediment-related parameters for PERLNDs were adjusted so that simulated sediment yields compared reasonably with results from field data.

Ockerman and Petri (2001, p. 19), in a study of five cropland watersheds in Nueces and Kleberg Counties, reported an average sediment yield of 610 pounds per acre during 199698. Ockerman and Fernandez (2010, p. 20), in a study of two primarily cropland watersheds in the Oso Creek watershed in Nueces County, reported average sediment runoff yields of 139 and 522 pounds per acre during 2005-08. In a study of sediment runoff from two rangeland study sites in San Patricio County, Ockerman (2002) reported an average sediment yield of 28 pounds per year during 2000-2001.

Estimates of suspended-solids concentrations in runoff from developed land uses and land covers were compiled for the South Texas area in a study by Baird and others (1996). Median event-mean concentrations for residential, commercial, industrial, and transportation land uses were compiled from a literature review. These event-mean concentrations were used to develop estimates of sediment loads in the Oso Creek watershed for 1989-93. The average sediment yield for developed land (including residential, commercial, industrial, and transportation land uses) was 52 pounds per acre per year (Baird and others, 1996, p. 199-218). A summary of sediment yields for selected land-use/land-cover categories is listed in table 6 . The yields from the literature review were used as calibration target values for model simulations. For comparison, table 6 also lists simulated sediment yields for selected land uses and land covers for 1989-2008 in the lower Nueces River watershed. HSPF parameter values related to sediment production (sediment detachment and washoff process) were iteratively adjusted until simulated yields approximated the target yields determined from the literature review.

Annual sediment yields simulated for cropland varied from 200 to 530 pounds per acre per year depending on crop, soil type, and rainfall. Annual sediment yields simulated for rangeland were 39 to 55 pounds per acre per year; for developed land were 38 to 75 pounds per acre per year; and for open/undeveloped land were 120 to 340 pounds per acre per year. In the part of the study area where sediment yields were 

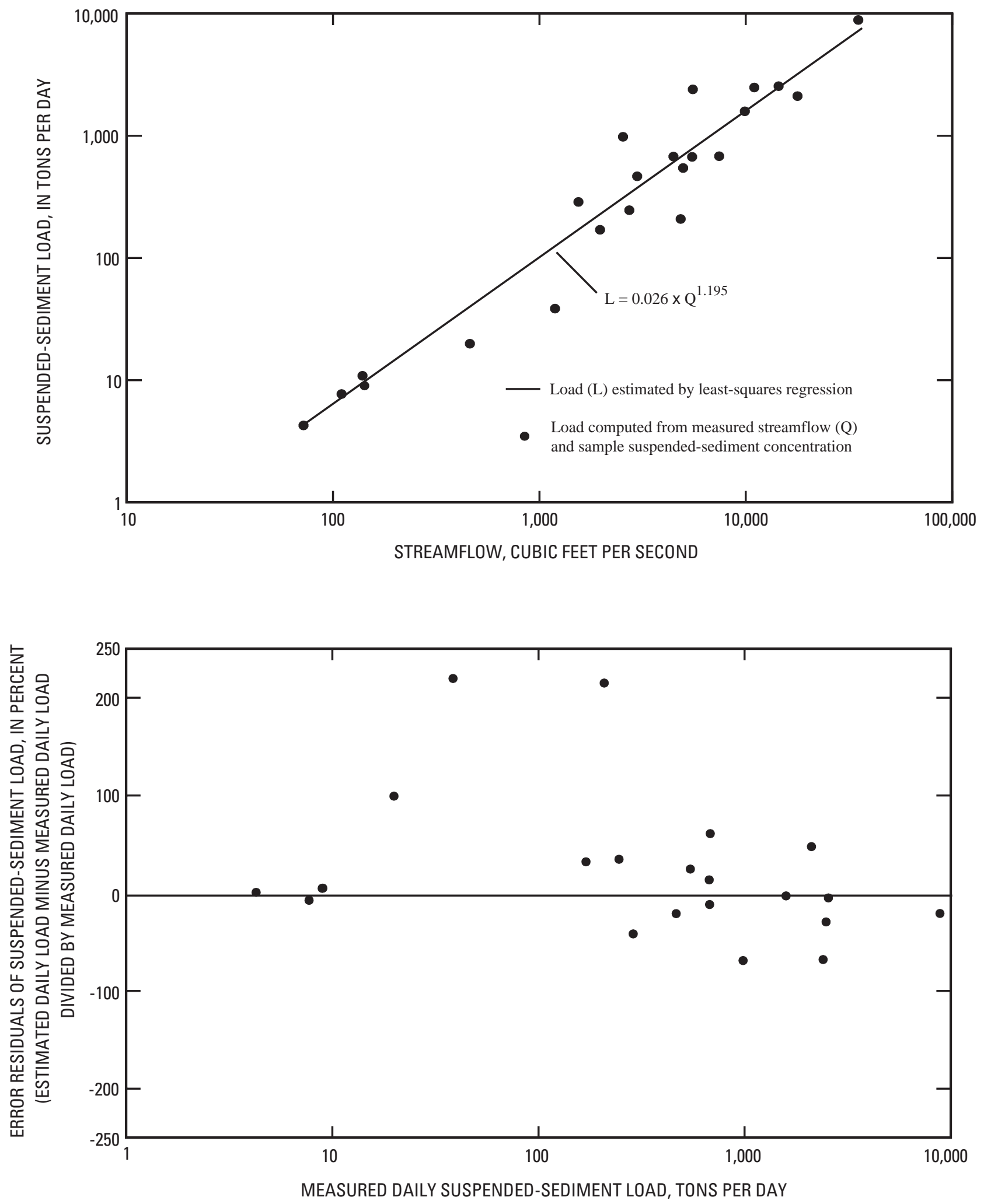

Figure 13. Relation between streamflow and suspended-sediment load and plot of regression error residuals based on 22 streamflowload data pairs from 08211000 Nueces River near Mathis, Texas, 1964-71 and 2006-07. 
Table 5. Measured and simulated streamflows, measured suspended-sediment particle size, and measured and simulated suspendedsediment concentrations and loads for selected samples collected at 08211000 Nueces River near Mathis, Texas, 2006-07.

[ft $3 / \mathrm{s}$, cubic feet per second; mm, millimeters; $\mathrm{mg} / \mathrm{L}$, milligrams per liter]

\begin{tabular}{|c|c|c|c|c|c|c|c|c|}
\hline Sample date & $\begin{array}{c}\text { Measured } \\
\text { streamflow } \\
\left(\mathrm{ft}^{3} / \mathbf{s}\right)\end{array}$ & $\begin{array}{c}\text { Simulated } \\
\text { streamflow } \\
\left(\mathrm{ft}^{3} / \mathbf{s}\right)\end{array}$ & $\begin{array}{c}\text { Measured } \\
\text { sediment } \\
\text { particle } \\
\text { diameter less } \\
\text { than } 0.0625 \mathrm{~mm} \\
\text { (percent) } \\
\end{array}$ & $\begin{array}{c}\text { Measured } \\
\text { suspended- } \\
\text { sediment } \\
\text { concentration } \\
(\mathrm{mg} / \mathrm{L})\end{array}$ & $\begin{array}{c}\text { Simulated } \\
\text { suspended- } \\
\text { sediment } \\
\text { concentration } \\
\text { (mg/L) }\end{array}$ & $\begin{array}{c}\text { Measured } \\
\text { suspended- } \\
\text { sediment } \\
\text { load } \\
\text { (tons per day) }\end{array}$ & $\begin{array}{c}\text { Simulated } \\
\text { suspended- } \\
\text { sediment } \\
\text { load } \\
\text { (tons per day) }\end{array}$ & $\begin{array}{c}\text { Error in } \\
\text { suspended- } \\
\text { sediment } \\
\text { load } \\
\text { (percent) }^{2}\end{array}$ \\
\hline May 17, 2006 & 139 & 137 & 98 & 24 & 28 & 9.0 & 10 & 11 \\
\hline July 20, 2006 & 110 & 117 & 88 & 26 & 31 & 7.7 & 10 & 30 \\
\hline Sept. 5, 2006 & 138 & 136 & 99 & 24 & 28 & 8.9 & 10 & 12 \\
\hline Nov. 20, 2006 & 72 & 71 & 94 & 22 & 48 & 4.3 & 9.3 & 116 \\
\hline May 26, 2007 & 461 & 511 & 99 & 16 & 12 & 20 & 17 & -15 \\
\hline May 29, 2007 & 1,190 & 1,270 & 98 & 12 & 11 & 39 & 35 & -10 \\
\hline July 1, 2007 & 4,830 & 5,120 & 98 & 16 & 18 & 208 & 235 & 13 \\
\hline July 11, 2007 & 17,800 & 17,600 & 86 & 44 & 45 & 2,110 & 2,100 & -.5 \\
\hline
\end{tabular}

${ }^{1}$ Percent by weight of sediment sample that passes through $0.0625-\mathrm{mm}$ sieve.

${ }^{2}$ Error $=[($ simulated-measured $) /$ measured $] \times 100$.

simulated using NWS rainfall data from Robstown, sediment yields were larger for all land types compared with sediment yields for the part of the study area where sediment yields were simulated using NWS rainfall data from Mathis. The main reason for differences in sediment yields were differences in the amount of rainfall measured during 2000-2008 at the NWS stations for the two parts of the study area; average annual rainfall amounts recorded by the NWS during 20002008 were 34.1 inches at Robstown and 26.8 inches at Mathis.

\section{Model Calibration}

For parameters related to sediment erosion from various land types, model calibration was based on available studies and data collected during 1989-2008. Therefore, calibration of PERLND parameters was based on simulations from the same period, 1989-2008. Model calibration of RCHRES suspendedsediment processes was based primarily on data collected at the Bluntzer and Calallen gages during 2006-07. These data were used to develop estimates of suspended-sediment loads for 2001-08, which were then compared with model simulation results.

Downstream from Lake Corpus Christi, at the Bluntzer and Calallen gages, suspended-sediment concentrations and loads in streams were calibrated to available suspended-sediment data collected by the USGS during 2006-07. RCHRES parameters related to sediment transport were adjusted (calibrated) to minimize the differences between measured and

Table 6. Comparison of literature estimates and simulation results for sediment yields from selected land covers and land uses in the lower Nueces River watershed and South Texas area.

[--, not applicable]

\section{Land-cover/land-use type}

Cropland (cultivated crop)

Rangeland (pasture, shrub, grassland)

Developed (commercial, transportation, residential, industrial)
Average 1989-2008

Sediment yield estimate (pounds per acre per year) from literature and reference simulated sediment yield (pounds per acre per year)

610 (Ockerman and Petri, 2001); 139 and 522 (Ockerman and Fernandez, 2010)

28 (Ockerman, 2002)

$39-55$

52 (Baird and others, 1996)

$38-75$ 
simulated sediment concentrations and computed (from measured concentrations and measured streamflows) and simulated loads. Instream transport and concentrations of sand are simulated by power functions that relate sand concentration to average RCHRES stream velocity. The power functions are calibrated by user-selected coefficients and exponents for each RCHRES. Proceeding in downstream order, the calibration process to determine suspended-sediment concentrations and loads was repeated for each RCHRES in the intervening areas between sediment-sampling stations. Suspended-sediment calibration results at the Bluntzer gage are listed in table 7. Table 7 also lists measured and simulated suspended-sediment concentrations and measured (computed) and simulated loads from 11 samples collected during 2006-07. Errors in simulated suspended-sediment loads at the Bluntzer gage (table 7) were generally larger compared with those at the Mathis gage (table 5), mostly because of differences in the amount of error associated with the simulation of streamflow. Overall, the amount of error associated with the simulation of streamflow at the Bluntzer gage was larger than the amount of error associated with the simulation of streamflow at the Mathis gage.

Although simulation errors for instantaneous or daily suspended-sediment loads were at times relatively large (139 percent for the January 25, 2007, sample; table 7), simulation errors for longer periods (for example, monthly or yearly) were deemed acceptable. The sum of simulated sediment loads for all 11 samples $(6,420$ tons per day) was within 1 percent of the sum of the measured (computed) sediment loads for all 11 samples $(6,360$ tons per day).

Suspended-sediment data were available for 10 suspended-sediment samples collected at the Calallen gage during 2006-07. Using these data, suspended-sediment loads were computed from daily mean streamflows and measured suspended-sediment concentrations. Similar to the approach used to estimate sediment loads from Lake Corpus Christi (fig. 13), the computed loads at Calallen were used to develop a regression equation to relate daily suspended-sediment loads to daily mean streamflow (fig. 14). The resulting equation was

$$
\mathrm{L}=0.119 \times \mathrm{Q}^{1.061}
$$

where

$\mathrm{L}=$ suspended-sediment load, in tons per day; and

$\mathrm{Q}=$ daily mean discharge, in cubic feet per second.

$\mathrm{R}^{2}$ for the regression equation was .87; RSE was 427 pounds per day. The residual plot on figure 14 shows regression residuals (as a percentage of the measured suspended-sediment load) plotted as a function of the measured suspendedsediment load. The distribution of the error residuals was relatively uniform, indicating a reasonable regression model.

The regression equation was then used to estimate suspended-sediment loads during 2001-08. The estimated daily suspended-sediment load computed using measured streamflow and sediment data was used as a calibration target to compare with simulated suspended-sediment loads at Calallen.
Model sediment-transport parameter values for RCHRESs downstream from the Calallen gage were adjusted on the basis of this comparison.

Calibration results for the Calallen gage (table 8) include a comparison of the average monthly streamflow volumes and suspended-sediment loads simulated using the HSPF model with the average monthly streamflow volumes measured at the gage and average monthly suspended-sediment loads estimated using equation 3 . Table 8 also lists the annual, monthly, and daily model-fit statistics for 2001-08. A graphical comparison (fig. 15) of estimated and simulated monthly suspended-sediment loads shows reasonable agreement over the range of suspended-sediment conditions during 2001-08. Suspended-sediment calibration results for individual samples collected at the Calallen gage are listed in table 9. Table 9 compares simulated suspended-sediment concentrations and loads with estimated suspended-sediment concentrations and loads computed from measured streamflow and suspendedsediment concentrations obtained from 10 samples collected during 2006-07.

During 2001-08, average monthly suspended-sediment loads at the Calallen gage were undersimulated by 4.2 percent (table 8), compared with the loads estimated by regression (equation 3). Model-fit statistics indicated the model simulates daily, monthly, and yearly sediment loads reasonably well. The NSE was .80 for daily simulations, increasing to .95 and .97 , respectively, for simulation of monthly and yearly suspendedsediment loads (table 8).

Donigian and others (1984) present general guidelines for characterizing HSPF sediment calibrations, similar to the guidelines for streamflow calibration. For annual and monthly sediment loads, model calibration is considered very good when the error is less than 15 percent, good when the error is 15-25 percent, and fair when the error is 25-35 percent. By these guidelines, calibration results for suspended-sediment loads at the Calallen gage (table 8 ) are considered very good. The $\mathrm{R}^{2}$ and NSE values were considered acceptable for annual, monthly, and daily statistics.

\section{Parameter Calibration Values}

Calibration and testing of the HSPF model resulted in a final set of model parameter values for simulation of streamflow and suspended-sediment loads for the study area. Calibrated values (or ranges of values) for selected parameters related to hydrology simulation are listed in table 10, and calibrated values (or ranges of values) for selected sedimentrelated parameters used in the HSPF model are listed in table 11.

\section{Sensitivity Analysis}

Calibrated values of selected HSPF process-related parameters were further evaluated by doing a sensitivity analysis to determine the effects that changes in the selected 

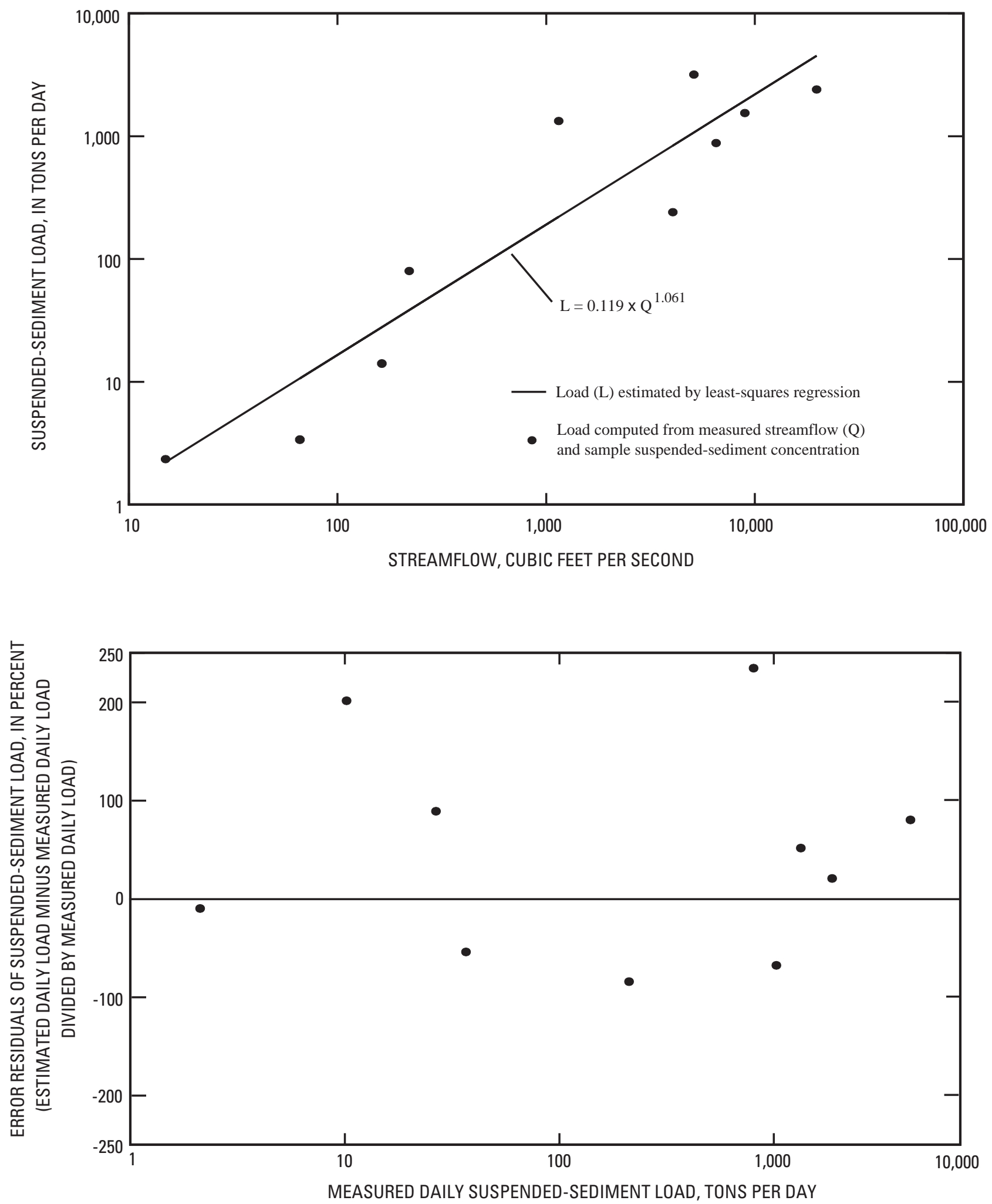

Figure 14. Relation between streamflow and suspended-sediment load and plot of regression error residuals based on 10 streamflowload data pairs from 08211500 Nueces River at Calallen, Texas, 2006-07. 

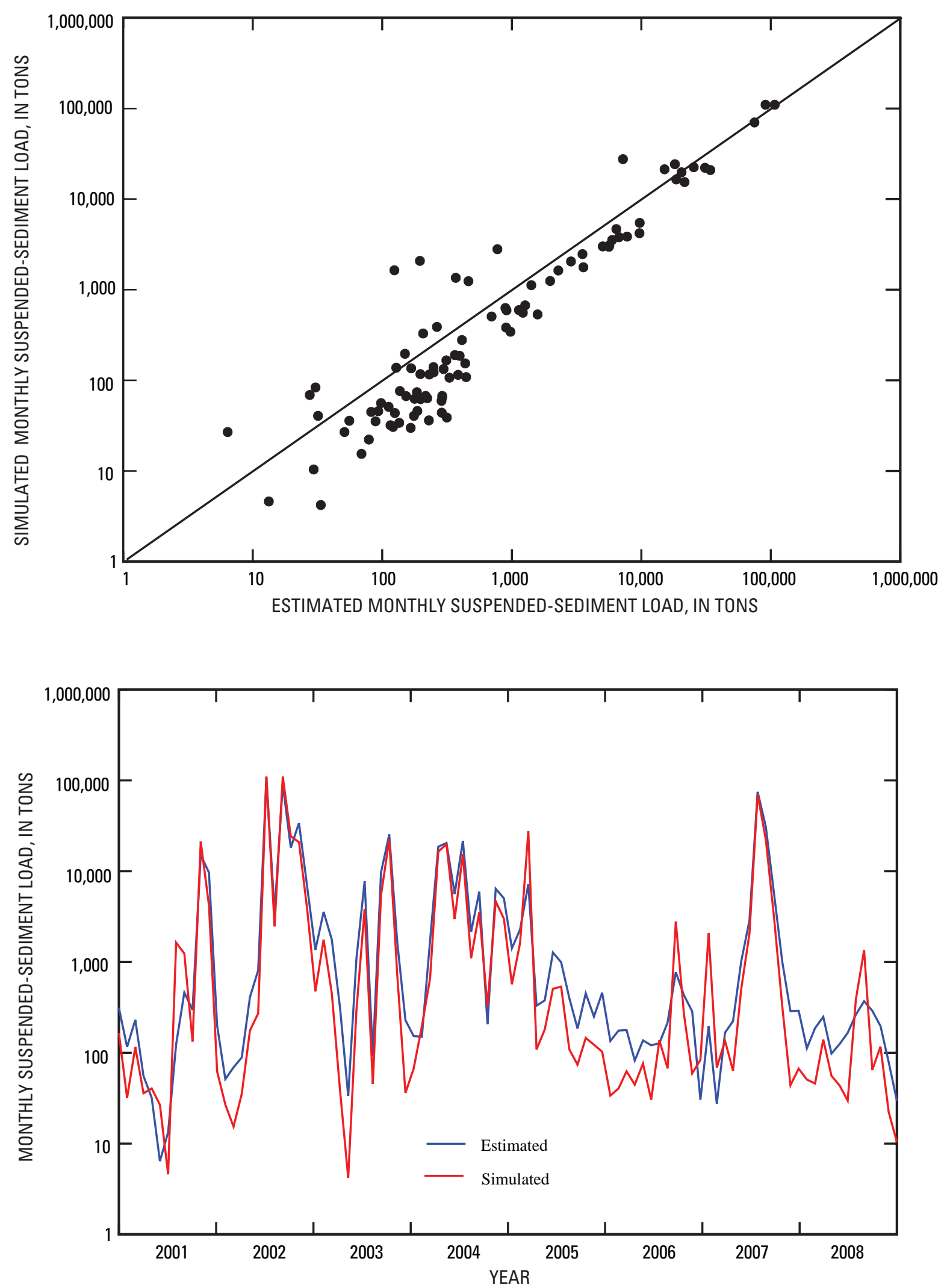

Figure 15. Estimated (by regression) and simulated monthly suspended-sediment loads for 08211500 Nueces River at Calallen, Texas, 2001-08. 
Table 7. Measured and simulated streamflows, measured suspended-sediment particle size, and measured and simulated suspendedsediment concentrations and loads for selected samples collected at 08211200 Nueces River at Bluntzer, Texas, 2006-07.

[ft $3 / \mathrm{s}$, cubic feet per second; mm, millimeters; $\mathrm{mg} / \mathrm{L}$, milligrams per liter]

\begin{tabular}{|c|c|c|c|c|c|c|c|c|}
\hline Sample date & $\begin{array}{c}\text { Measured } \\
\text { streamflow } \\
\left(\mathrm{ft}^{3} / \mathbf{s}\right)\end{array}$ & $\begin{array}{c}\text { Simulated } \\
\text { streamflow } \\
\left(\mathrm{ft}^{3} / \mathrm{s}\right)\end{array}$ & $\begin{array}{l}\text { Measured } \\
\text { sediment } \\
\text { particle diam- } \\
\text { eter less than } \\
0.0625 \mathrm{~mm} \\
\text { (percent) }{ }^{1}\end{array}$ & $\begin{array}{c}\text { Measured } \\
\text { suspended- } \\
\text { sediment } \\
\text { concentration } \\
(\mathrm{mg} / \mathrm{L})\end{array}$ & $\begin{array}{c}\text { Simulated } \\
\text { suspended- } \\
\text { sediment } \\
\text { concentration } \\
\text { (mg/L) }\end{array}$ & $\begin{array}{c}\text { Measured } \\
\text { suspended- } \\
\text { sediment load } \\
\text { (tons per day) }\end{array}$ & $\begin{array}{c}\text { Simulated } \\
\text { suspended- } \\
\text { sediment load } \\
\text { (tons per day) }\end{array}$ & $\begin{array}{c}\text { Error in } \\
\text { suspended- } \\
\text { sediment load } \\
(\text { percent) })^{2}\end{array}$ \\
\hline May 17, 2006 & 121 & 136 & 97 & 48 & 22 & 16 & 8.3 & -48 \\
\hline July 20, 2006 & 116 & 118 & 88 & 51 & 25 & 16 & 7.9 & -51 \\
\hline Sept. 5, 2006 & 136 & 129 & 97 & 52 & 23 & 19 & 8.1 & -57 \\
\hline Sep. 19, 2006 & 1,050 & 1,370 & 97 & 1,070 & 468 & 3,030 & 1,730 & -43 \\
\hline Nov. 20, 2006 & 82 & 71 & 89 & 25 & 35 & 5.5 & 6.8 & 24 \\
\hline Jan. 4, 2007 & 153 & 344 & 81 & 293 & 344 & 121 & 238 & 97 \\
\hline Jan. 25, 2007 & 243 & 970 & 99 & 760 & 455 & 498 & 1,190 & 139 \\
\hline May 26, 2007 & 471 & 405 & 100 & 94 & 38 & 119 & 41 & -66 \\
\hline May 29, 2007 & 1,330 & 1,170 & 97 & 54 & 44 & 194 & 140 & -28 \\
\hline July 1, 2007 & 5,980 & 6,290 & 92 & 45 & 33 & 726 & 553 & -24 \\
\hline July 11, 2007 & 15,000 & 14,400 & 79 & 40 & 64 & 1,620 & 2,500 & 54 \\
\hline
\end{tabular}

${ }^{1}$ Percent by weight of sediment sample that passes through $0.0625-\mathrm{mm}$ sieve.

${ }^{2}$ Error $=[($ simulated-measured $) /$ measured $] \times 100$.

Table 8. Suspended-sediment calibration results for the Hydrological Simulation Program—FORTRAN model of the lower Nueces River watershed, South Texas, 2001-08.

08211500 Nueces River at Calallen, Texas

\begin{tabular}{lcr}
\hline Average monthly streamflow volumes and suspended-sediment loads & $\begin{array}{c}\text { Measured/ } \\
\text { estimated }^{1}\end{array}$ & $\begin{array}{c}\text { Simulated } \\
\text { (percent) }^{2}\end{array}$ \\
\hline Flow volume (acre-feet) & 58,500 & 56,400 \\
Suspended-sediment load (tons) & 5,910 & -3.6 \\
\end{tabular}

\begin{tabular}{lccc}
\hline \multicolumn{1}{c}{ Model-fit statistics for suspended-sediment loads 2001-08 } & Annual & Monthly & Daily \\
\hline Coefficient of determination $\left(\mathrm{R}^{2}\right)$ & 0.98 & 0.96 & 0.82 \\
Nash-Sutcliffe coefficient of model-fit efficiency (NSE) & .97 & .95 & .80 \\
Mean absolute error (tons) & 12,200 & 1,640 & 84.4 \\
Mean absolute error (percent) & 17.1 & 27.8 & 43.4 \\
Root mean square error (tons) & 15,500 & 4,270 & 444 \\
\hline
\end{tabular}

\footnotetext{
${ }^{1}$ Streamflow volumes at 08211500 are measured values; suspended-sediment loads are estimated by regression of measured streamflow and suspended-sediment loads calculated from streamflow and measured suspended-sediment concentrations for 10 sampling events during 2006-07.

${ }^{2}$ Error $=[($ simulated-measured $/$ measured $)] \times 100$.
} 
Table 9. Measured and simulated streamflows, measured suspended-sediment particle size, and measured and simulated suspendedsediment concentrations and loads for selected samples collected at 08211500 Nueces River at Calallen, Texas, 2006-07.

[ $\mathrm{ft}^{3} / \mathrm{s}$, cubic feet per second; mm, millimeters; $\mathrm{mg} / \mathrm{L}$, milligrams per liter]

\begin{tabular}{|c|c|c|c|c|c|c|c|c|}
\hline Sample date & $\begin{array}{c}\text { Measured } \\
\text { streamflow } \\
\left(\mathrm{ft}^{3} / \mathbf{s}\right)\end{array}$ & $\begin{array}{c}\text { Simulated } \\
\text { streamflow } \\
\left(\mathrm{ft}^{3} / \mathrm{s}\right)\end{array}$ & $\begin{array}{c}\text { Measured sedi- } \\
\text { ment particle } \\
\text { diameter less } \\
\text { than } 0.0625 \mathrm{~mm} \\
\text { (percent) }^{1}\end{array}$ & $\begin{array}{l}\text { Measured } \\
\text { suspended- } \\
\text { sediment } \\
\text { concentration } \\
\text { (mg/L) }\end{array}$ & $\begin{array}{c}\text { Simulated } \\
\text { suspended- } \\
\text { sediment } \\
\text { concentration } \\
\text { (mg/L) }\end{array}$ & $\begin{array}{c}\text { Measured } \\
\text { suspended- } \\
\text { sediment load } \\
\text { (tons per day) }\end{array}$ & $\begin{array}{c}\text { Simulated } \\
\text { suspended- } \\
\text { sediment load } \\
\text { (tons per day) }\end{array}$ & $\begin{array}{c}\text { Error in } \\
\text { suspended- } \\
\text { sediment load } \\
\text { (percent) }{ }^{2}\end{array}$ \\
\hline May 16, 2006 & 15 & 22 & 82 & 58 & 27 & 2.3 & 1.4 & -39 \\
\hline Sept. 19, 2006 & 1,150 & 1,340 & 100 & 429 & 316 & 1,330 & 992 & -25 \\
\hline Jan. 25, 2007 & 163 & 455 & 89 & 32 & 98 & 14 & 161 & 1,050 \\
\hline Mar. 15, 2007 & 221 & 170 & 32 & 134 & 74 & 80 & 40 & -50 \\
\hline July 2, 2007 & 5,100 & 7,360 & 94 & 231 & 44 & 3,180 & 871 & -73 \\
\hline Aug. 16, 2007 & 4,050 & 4,610 & 94 & 22 & 24 & 241 & 296 & 23 \\
\hline
\end{tabular}

${ }^{1}$ Percent by weight of sediment sample that passes through $0.0625-\mathrm{mm}$ sieve.

${ }^{2}$ Error $=[($ simulated-measured $) /$ measured $] \times 100$.

parameters would have on simulated streamflow and suspended-sediment loads. Each sensitivity simulation was made by adjusting a single parameter of the model by relatively large amounts (increased by 40 percent) while keeping other model parameters unchanged. The sensitivity analysis model runs were performed for 2001-08. The resulting changes in streamflow and suspended-sediment loads were evaluated at the inflow to RCHRES 97, which is considered the inflow to the Nueces Estuary. The changes in streamflow and suspended-sediment loads resulting from adjustments of selected parameters are listed in table 12.

Simulated streamflow was relatively insensitive to adjustments of any of the selected parameters. One reason is that most of the streamflow, which is simulated in the model as an input boundary condition, originates as inflow from Lake Corpus Christi releases. In the sensitivity analysis, the parameters that had the largest effects on simulated suspendedsediment loads were the index to infiltration capacity of soil (INFILT), lower-zone nominal storage (LZSN), and coefficient of detached-sediment washoff equation (KSER). Overall, changes in suspended-sediment loads when these parameters were adjusted were comparatively small compared with the changes applied to the parameter values. The INFILT parameter had the largest effect on simulated suspended-sediment loads; a 40-percent increase in the INFILT parameter resulted in a 7.1-percent decrease in the simulated suspended-sediment load. For the other parameters examined for sensitivity, increases in parameter values of 40 percent resulted in changes to the simulated suspended-sediment load ranging from -3.2 to 4.9 percent (table 12).

\section{Model Limitations}

Errors in model calibration can be classified as systematic or measurement errors (Raines, 1996). Systematic errors are those that arise because of the model's failure to adequately represent the hydrologic and water-quality processes of the study watershed. As a result, there are limits to how well model parameters and equations can replicate the complex physical properties of streamflow and water-quality processes.

Measurement errors are those that are introduced as a result of inaccurate or missing data. The degree to which available rainfall data represent actual rainfall is potentially the most serious source of measurement error associated with this model; limitations in the amount of available rainfall data are often a serious source of measurement error for a watershed modeling study (Ockerman and Roussel, 2009). In the lower Nueces River watershed model, rainfall was applied to the study area using data from two locations-Mathis and Robstown NWS stations. Long-term rainfall totals from these two stations are likely representative of long-term study-area conditions. However, the lack of additional rainfall gages severely limits spatial resolution of rainfall input to the 218-square-mile study area, especially for relatively large storm events. Typically, measurements of extreme values of rainfall at a single location, when used to simulate average 
Table 10. Summary of calibrated values for selected hydrologic parameters for the Hydrological Simulation Program—FORTRAN model of the lower Nueces River watershed, South Texas.

[PERLND, pervious land surface; --, none; IMPLND, impervious land surface]

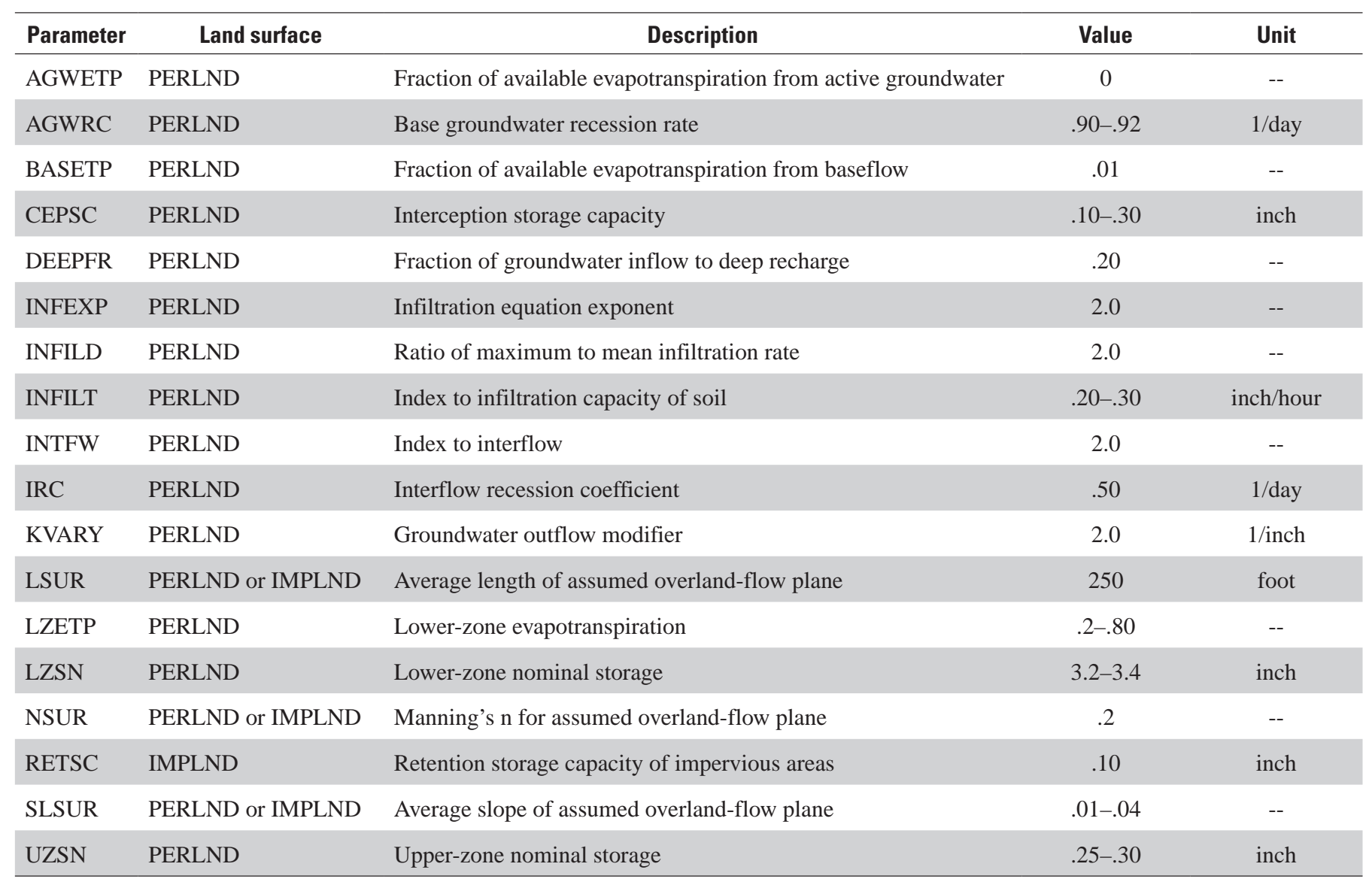

rainfall for larger areas (such as the lower Nueces River watershed) tend to overestimate the average rainfall of the watershed (Asquith, 1999). Also, the overestimation increases as the size of the watershed increases; the fewer rain gages available for a study area, the greater the probability that rainfall in the study area is overestimated during large storms.

Another limitation of the rainfall data used for the model was that all data from the Mathis NWS station and much of the data from the Robstown NWS station were only available as daily totals. These daily totals were disaggregated to hourly values based on theoretical temporal distributions. As a result, some loss of accuracy in the timing and intensity of rainfall might have been incorporated into the model results.

Overall, streamflow was simulated with reasonable accuracy at the streamflow-gaging stations in the study area. Most of the streamflow originating in the study area was from Lake Corpus Christi releases and was measured by the Mathis gage. The Bluntzer gage was a partial-record station and did not record streamflows greater than 2,750 cubic feet per second. Similar to streamflow at the Mathis gage, streamflow at the Bluntzer gage was largely controlled by releases from Lake Corpus Christi. The accuracy of simulated streamflow at the Bluntzer gage might have been diminished during periods when additional runoff downstream from Lake Corpus Christi was occurring. Streamflow simulation results at the Calallen gage were generally very good. Low flows at the Calallen gage (streamflows of less than about 10 cubic feet per second) exhibited greater error compared with higher flows (fig. 12, middle graph). The errors in low flows at the Calallen gage were possibly a result of withdrawals upstream from the gage, which were only available as monthly totals. Because only monthly totals were available to represent the withdrawals upstream, hourly and daily streamflows at the Calallen gage during low-flow periods were subject to greater uncertainty compared with monthly or annual flows.

Suspended-sediment simulations also were affected by uncertainties in parameters associated with rainfall and streamflow. For example, overestimation of rainfall parameters (in particular, rainfall intensity) would increase soil particle detachment and washoff of sediment from PERLNDs, resulting in possible oversimulation of runoff and suspendedsediment concentrations and loads.

How well the model represents basin-wide suspendedsediment yields for various land types is somewhat uncertain. Calibration of basin-wide suspended-sediment yields depends on reasonable estimates of sediment yields from various 
Table 11. Summary of calibrated values for selected sediment-related parameters for the Hydrological Simulation ProgramFORTRAN model of the lower Nueces River watershed, South Texas.

[PERLND, pervious land surface; IMPLND, impervious land surface; RCHRES, stream/reservoir reach]

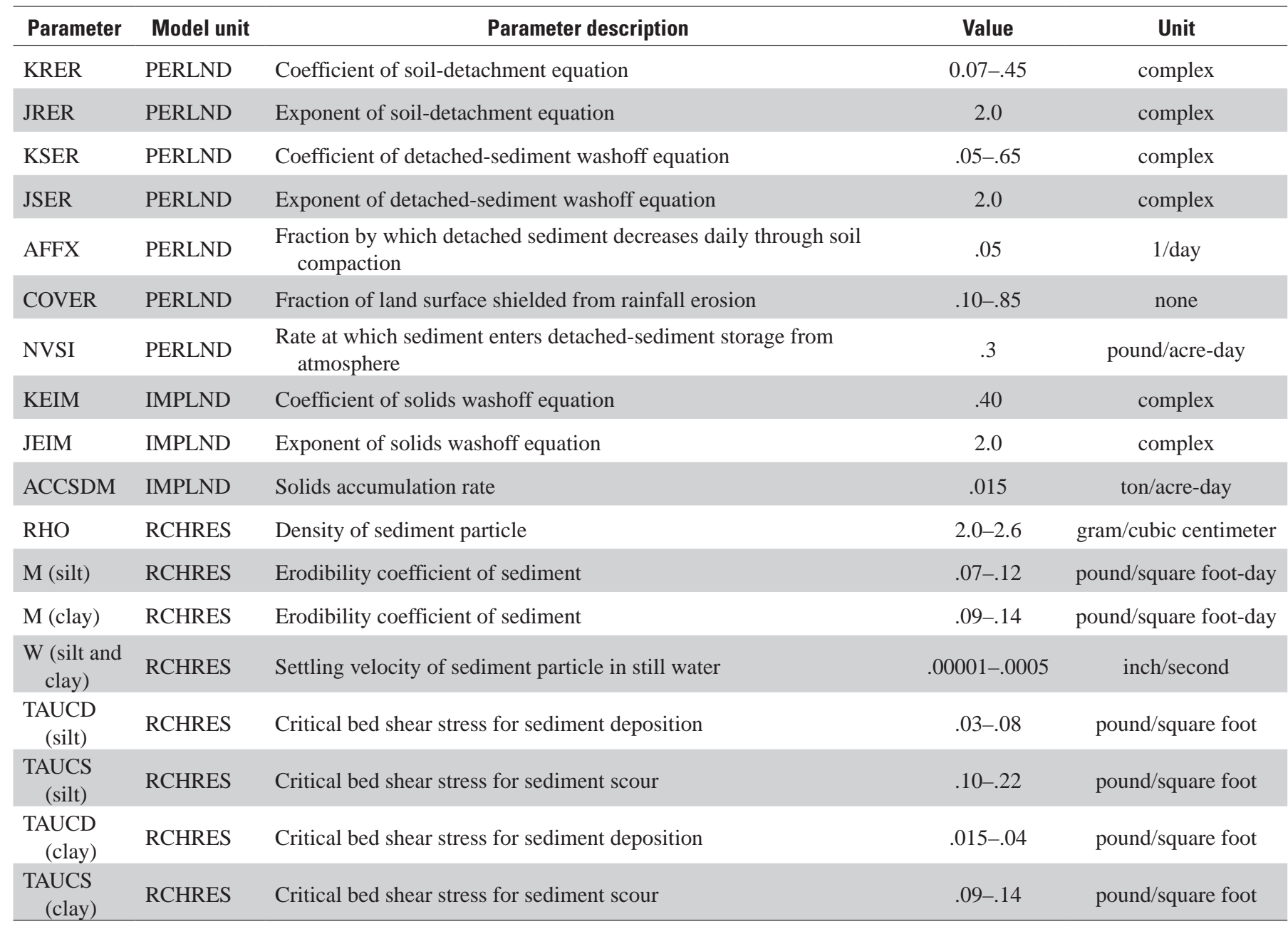

land types. Several studies of suspended-sediment yields for specific land types provided guidance for establishing target yields for calibration. The target yields were reasonably simulated by the model —albeit the sediment-yield studies used to establish the targets were limited in scope compared with the size of the study watershed and variety of land uses and land covers in the lower Nueces River watershed.

Overall, suspended-sediment calibration results were very good for monthly and annual suspended-sediment loads. Relatively large errors were associated with simulated daily suspended-sediment loads (table 8 ) and with suspendedsediment load estimated for individual samples (table 9).

\section{Estimated Suspended-Sediment Loads to the Nueces Estuary, 1958-2008}

The calibrated model of the lower Nueces River watershed was used to estimate suspended-sediment loads to the Nueces Estuary for 1958-2008, as well as sediment loading rates (mass per unit area) and sediment loads simulated for the different land types and within different geographic areas. The model configuration and parameter values that were used for the 2001-08 calibration period were retained for the 19582008 simulation period. The rainfall and potential evapotranspiration data used for modeling 1958-2008 were obtained from the same NWS stations used for calibration.

The location chosen for modeling delivery of the suspended-sediment load to the Nueces Estuary was USGS streamflow-gaging station 08211502 Nueces River near Odem, Tex. (hereinafter the Odem gage) (site 11, fig. 10; table 3). The Odem gage is located in the tidal reach of the Nueces River at Interstate Highway 37, about 1.1 miles downstream from the Calallen gage and 0.2 mile downstream from the confluence of Hondo Creek and the Nueces River (near the confluence of RCHRESs 95 and 96, or the inflow to RCHRES 97; fig. 9).

Estimated annual suspended-sediment loads, in tons per day, transported during 1958-2008 to the Nueces Estuary are shown on figure 16 and listed in table 13 . The annual mean 
Table 12. Sensitivity of simulated streamflow volumes and suspended-sediment loads to changes in selected process-related parameters for the lower Nueces River watershed model, South Texas.

[DEEPFR, fraction of groundwater inflow to deep recharge; INFILT, index to infiltration capacity of soil; LZSN, lower-zone nominal storage; KRER, coefficient of soil-detachment equation; KSER, coefficient of detached-sediment washoff equation; M (silt), erodibility coefficient of silt sediment; M (clay), erodibility coefficient of clay sediment]

\begin{tabular}{lccccc}
\hline Parameter & Initial value & Adjusted value & $\begin{array}{c}\text { Change in parameter } \\
\text { value } \\
\text { (percent) }\end{array}$ & $\begin{array}{c}\text { Change in streamflow } \\
\text { volume } \\
\text { (percent) }\end{array}$ & $\begin{array}{c}\text { Change in suspended- } \\
\text { sediment load } \\
\text { (percent) }\end{array}$ \\
\hline DEEPFR & 0.20 & 0.28 & 40 & -0.6 & -0.5 \\
INFILT & $.20-.30$ & $.28-.42$ & 40 & -.2 & -7.1 \\
LZSN & $3.20-3.40$ & $4.48-4.76$ & 40 & -1.0 & -3.2 \\
KRER & $.07-.45$ & $.10-.63$ & 40 & 0 & 0 \\
KSER & $.05-.65$ & $.07-.91$ & 40 & 0 & 4.9 \\
M (silt) & $.07-.12$ & $.10-.17$ & 40 & 0 & 2.1 \\
M (clay) & $.09-.14$ & $.13-.20$ & 40 & 0 & 1.1 \\
\hline
\end{tabular}

${ }^{1}$ Simulation period for sensitivity analyses, 2001-08.

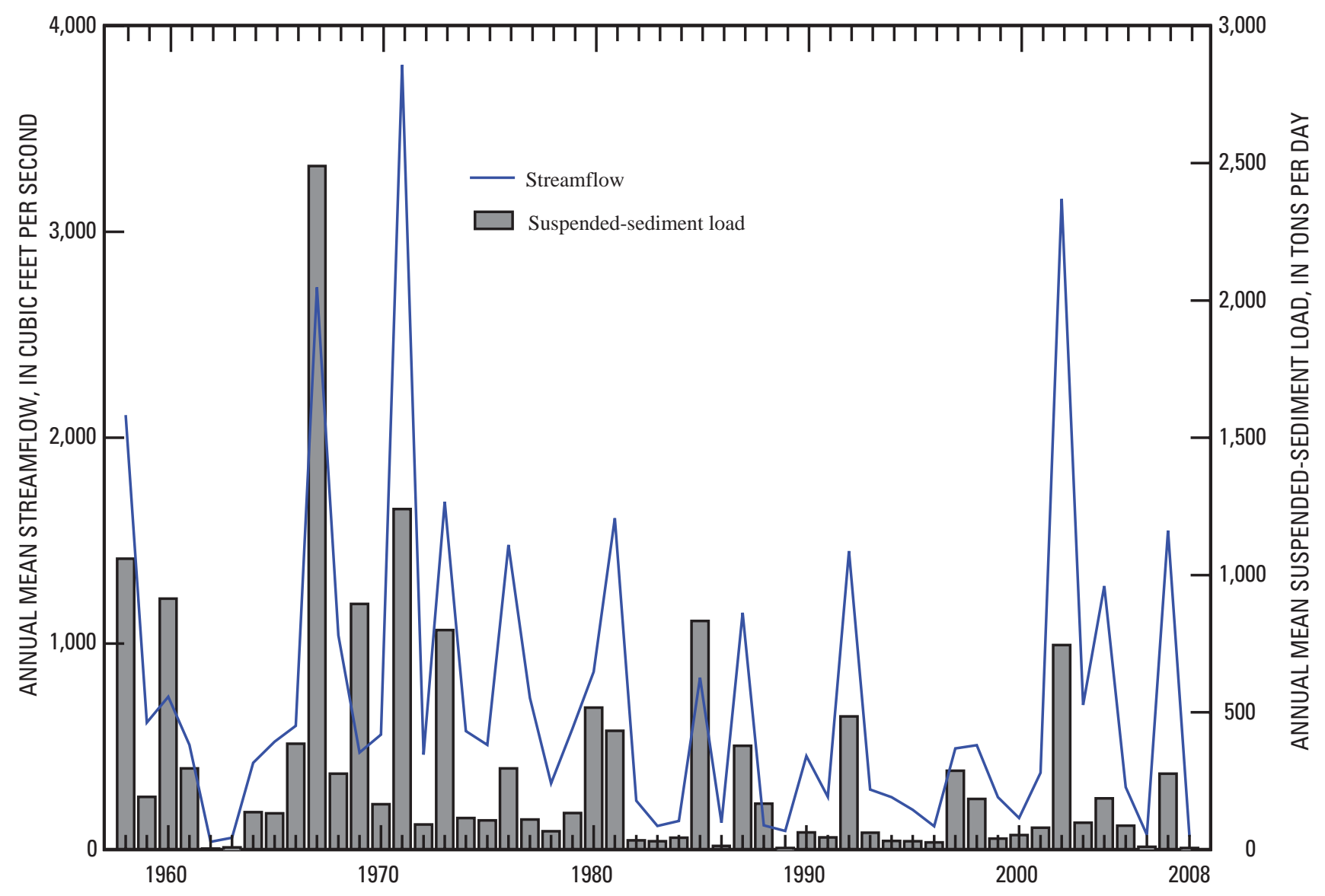

Figure 16. Estimated annual streamflow and suspended-sediment loads to the Nueces Estuary, South Texas, 1958-2008. 
Table 13. Estimated annual streamflows and suspended-sediment loads to the Nueces Estuary, South Texas, 1958-2008.

\begin{tabular}{|c|c|c|c|}
\hline Year & $\begin{array}{l}\text { Annual mean streamflow } \\
\text { (cubic feet per second) }\end{array}$ & $\begin{array}{l}\text { Annual suspended-sediment load } \\
\text { (tons) }\end{array}$ & $\begin{array}{l}\text { Annual mean suspended-sediment load } \\
\text { (tons per day) }\end{array}$ \\
\hline 1958 & 2,030 & 387,160 & 1,060 \\
\hline 1959 & 591 & 70,100 & 192 \\
\hline 1960 & 816 & 334,000 & 914 \\
\hline 1961 & 431 & 108,000 & 296 \\
\hline 1962 & 38 & 1,390 & 3.8 \\
\hline 1963 & 58 & 2,820 & 7.7 \\
\hline 1964 & 421 & 50,000 & 137 \\
\hline 1965 & 529 & 48,400 & 133 \\
\hline 1966 & 598 & 141,000 & 386 \\
\hline 1967 & 2,740 & 909,500 & 2,490 \\
\hline 1968 & 1,040 & 101,000 & 277 \\
\hline 1969 & 486 & 327,000 & 895 \\
\hline 1970 & 544 & 60,400 & 165 \\
\hline 1971 & 3,820 & 452,910 & 1,240 \\
\hline 1972 & 452 & 33,400 & 91 \\
\hline 1973 & 1,690 & 292,000 & 799 \\
\hline 1974 & 572 & 42,100 & 115 \\
\hline 1975 & 507 & 39,000 & 107 \\
\hline 1976 & 1,500 & 108,000 & 296 \\
\hline 1977 & 716 & 40,000 & 110 \\
\hline 1978 & 324 & 24,500 & 67 \\
\hline 1979 & 586 & 48,600 & 133 \\
\hline 1980 & 862 & 189,000 & 517 \\
\hline 1981 & 1,620 & 158,000 & 433 \\
\hline 1982 & 236 & 12,500 & 34 \\
\hline 1983 & 123 & 11,100 & 30 \\
\hline 1984 & 144 & 15,800 & 43 \\
\hline 1985 & 822 & 304,000 & 832 \\
\hline 1986 & 144 & 4,880 & 13 \\
\hline 1987 & 1,140 & 138,000 & 378 \\
\hline 1988 & 117 & 61,300 & 168 \\
\hline 1989 & 91 & 2,220 & 6.1 \\
\hline 1990 & 453 & 22,700 & 62 \\
\hline 1991 & 276 & 16,300 & 45 \\
\hline 1992 & 1,430 & 177,000 & 485 \\
\hline 1993 & 290 & 22,300 & 61 \\
\hline 1994 & 259 & 11,600 & 32 \\
\hline 1995 & 190 & 11,100 & 30 \\
\hline 1996 & 111 & 9,720 & 27 \\
\hline 1997 & 491 & 105,000 & 287 \\
\hline 1998 & 510 & 67,400 & 185 \\
\hline 1999 & 252 & 14,600 & 40 \\
\hline 2000 & 156 & 19,500 & 53 \\
\hline 2001 & 371 & 29,000 & 79 \\
\hline 2002 & 3,170 & 272,000 & 745 \\
\hline 2003 & 692 & 35,700 & 98 \\
\hline 2004 & 1,290 & 68,200 & 187 \\
\hline 2005 & 292 & 31,700 & 87 \\
\hline 2006 & 79 & 3,700 & 10 \\
\hline 2007 & 1,550 & 101,000 & 277 \\
\hline 2008 & 64 & 2,320 & 6.4 \\
\hline $\begin{array}{l}\text { 1958-2008 } \\
\text { average annual }\end{array}$ & 739 & 108,600 & 297 \\
\hline
\end{tabular}


suspended-sediment load was highly variable, ranging from an estimated 3.8 tons per day in 1962 to 2,490 tons per day in 1967 . The daily mean suspended-sediment load during 1958-2008 was an estimated 297 tons per day. The median suspended-sediment load was an estimated 133 tons per day.

Estimated annual mean sediment loads at the Nueces Estuary (Odem gage) were compared with those estimated at the Mathis gage (outflow of Lake Corpus Christi) and at the Bluntzer and Calallen gages (table 14). These comparisons give an indication of sources of sediment delivered to the Nueces River and Nueces Estuary.

Estimated annual suspended-sediment loads in the lower Nueces River simulated by the model for each major source of sediment in the study area are listed by category in table 15. On average, an estimated 307 tons per day of suspended sediment were delivered to the lower Nueces River; an estimated 297 tons per day were delivered to the Nueces Estuary. Releases from Lake Corpus Christi delivered an estimated 98 tons per day of suspended sediment or 32 percent of the 307 tons per day estimated to have been delivered to the lower Nueces River. This indicated that, on average, about 209 tons per day of sediment, or 68 percent of the estimated 307 tons per day total were generated from erosion of land surfaces and stream-channel bed and banks. The largest source of sediment originating from within the study area was generated from cropland, about 117 tons per day, or about 38 percent of the total estimated for all sources each year, on average. Erosion of stream-channel bed and banks accounted for, on average, 55 tons per day, or 18 percent of the estimated total suspendedsediment load. All other land categories, except cropland, accounted for an estimated 37 tons per day, or 12 percent of the total. An estimated 9.6 tons per day of suspended sediment or 3 percent of the suspended-sediment load delivered to the lower Nueces River were removed by water withdrawals before reaching the Nueces Estuary.
Model results indicate most of the sediment load in the Nueces River consists of silt and clay, defined as particle sizes less than 0.0625 millimeter. At the Bluntzer gage, simulated silt and clay loads composed about 99 percent of the total suspended-sediment load. At the Calallen gage, simulated silt and clay loads composed about 98 percent of the total suspended-sediment load.

Annual streamflows and suspended-sediment loads to the Nueces River and Nueces Estuary varied depending on rainfall and streamflow conditions. Annual suspendedsediment loads delivered to the estuary ranged from 3.8 tons per day in 1962 to 2,490 tons per day in 1967. Large rainfall and runoff events contributed most of the streamflow and suspended-sediment loads to the Nueces River. Whether the runoff occurred upstream or downstream from Lake Corpus Christi affected the amount of annual suspended-sediment loads that were contributed by the each of the main sources shown in table 15. During some years with relatively low annual average streamflow (1984, 1988, 1989, and 1995) net stream-channel erosion was negative, indicating net annual sediment deposition to the stream channel. Simulation results indicate that the largest sediment loads transported to the Nueces Estuary as a result of stream-channel bed and bank erosion occurred during years with relatively large annual mean streamflows (for example, 1958, 1967, and 1971). During low-flow years, relatively large percentages of the total suspended sediment transported to the Nueces River were removed by water withdrawals. For example, 2008 was a lowflow year; the annual mean streamflow of the Nueces River to the Nueces Estuary was 64 cubic feet per second in 2008 compared with annual median streamflow of 507 cubic feet per second measured during 1958-2008, and about 50 percent of the total suspended-sediment load was removed in 2008 by water withdrawals. 
Table 14. Estimated annual suspended-sediment loads at selected stations, lower Nueces River watershed, South Texas, $1958-2008$.

\begin{tabular}{|c|c|c|c|c|}
\hline \multirow{2}{*}{ Year } & \multicolumn{4}{|c|}{$\begin{array}{l}\text { Suspended-sediment load } \\
\text { (tons per day) }\end{array}$} \\
\hline & $\begin{array}{l}08211000 \text { Nueces River } \\
\text { near Mathis, Texas }\end{array}$ & $\begin{array}{l}08211200 \text { Nueces River } \\
\text { at Bluntzer, Texas }\end{array}$ & $\begin{array}{l}08211500 \text { Nueces River } \\
\text { at Calallen, Texas }\end{array}$ & $\begin{array}{l}08211502 \text { Nueces River } \\
\text { near Odem, Texas }\end{array}$ \\
\hline 1958 & 304 & 906 & 1,070 & 1,060 \\
\hline 1959 & 70 & 180 & 200 & 192 \\
\hline 1960 & 70 & 630 & 789 & 914 \\
\hline 1961 & 45 & 236 & 277 & 296 \\
\hline 1962 & 5.9 & 8.3 & 8.1 & 3.8 \\
\hline 1963 & 6.3 & 13 & 13 & 7.7 \\
\hline 1964 & 46 & 133 & 143 & 137 \\
\hline 1965 & 64 & 126 & 141 & 133 \\
\hline 1966 & 50 & 315 & 359 & 386 \\
\hline 1967 & 616 & 1,650 & 2,170 & 2,490 \\
\hline 1968 & 134 & 224 & 279 & 277 \\
\hline 1969 & 33 & 602 & 756 & 895 \\
\hline 1970 & 61 & 131 & 171 & 165 \\
\hline 1971 & 646 & 805 & 1,190 & 1,240 \\
\hline 1972 & 45 & 85 & 102 & 91 \\
\hline 1973 & 203 & 545 & 726 & 799 \\
\hline 1974 & 61 & 108 & 118 & 115 \\
\hline 1975 & 59 & 100 & 120 & 107 \\
\hline 1976 & 164 & 261 & 301 & 296 \\
\hline 1977 & 93 & 102 & 121 & 110 \\
\hline 1978 & 30 & 62 & 68 & 67 \\
\hline 1979 & 57 & 106 & 133 & 133 \\
\hline 1980 & 111 & 350 & 460 & 517 \\
\hline 1981 & 202 & 353 & 416 & 433 \\
\hline 1982 & 28 & 28 & 43 & 34 \\
\hline 1983 & 9.0 & 30 & 31 & 30 \\
\hline 1984 & 7.6 & 28 & 41 & 43 \\
\hline 1985 & 72 & 567 & 709 & 832 \\
\hline 1986 & 13 & 18 & 18 & 13 \\
\hline 1987 & 142 & 290 & 350 & 378 \\
\hline 1988 & 10 & 129 & 145 & 168 \\
\hline 1989 & 10 & 8.8 & 10 & 6.1 \\
\hline 1990 & 50 & 63 & 67 & 62 \\
\hline 1991 & 18 & 33 & 47 & 45 \\
\hline 1992 & 156 & 372 & 444 & 485 \\
\hline 1993 & 23 & 58 & 62 & 61 \\
\hline 1994 & 19 & 34 & 35 & 32 \\
\hline 1995 & 15 & 26 & 33 & 30 \\
\hline 1996 & 10 & 27 & 28 & 27 \\
\hline 1997 & 33 & 214 & 256 & 287 \\
\hline 1998 & 43 & 134 & 166 & 185 \\
\hline 1999 & 24 & 38 & 44 & 40 \\
\hline 2000 & 10 & 26 & 52 & 53 \\
\hline 2001 & 39 & 65 & 80 & 79 \\
\hline 2002 & 578 & 569 & 736 & 745 \\
\hline 2003 & 90 & 90 & 115 & 98 \\
\hline 2004 & 154 & 171 & 192 & 187 \\
\hline 2005 & 26 & 74 & 82 & 87 \\
\hline 2006 & 6.7 & 11 & 13 & 10 \\
\hline 2007 & 221 & 221 & 282 & 277 \\
\hline 2008 & 5.9 & 6.8 & 11.1 & 6.4 \\
\hline $\begin{array}{l}\text { 1958-2008 average } \\
\text { average }\end{array}$ & 98 & 223 & 279 & 297 \\
\hline
\end{tabular}


Table 15. Estimated annual streamflows and suspended-sediment loads, by sediment source, simulated by the Hydrological Simulation Program—FORTRAN model of the lower Nueces River watershed, South Texas, 1958-2008.

\begin{tabular}{|c|c|c|c|c|c|c|c|c|}
\hline \multirow[b]{2}{*}{ Year } & \multirow{2}{*}{$\begin{array}{l}\text { Annual mean } \\
\text { streamflow, } \\
\text { Nueces River } \\
\text { to Nueces } \\
\text { Estuary } \\
\text { (cubic feet } \\
\text { per second)' }\end{array}$} & \multicolumn{7}{|c|}{$\begin{array}{l}\text { Suspended-sediment load } \\
\text { (tons per day) }\end{array}$} \\
\hline & & $\begin{array}{l}\text { Inflow asso- } \\
\text { ciated with } \\
\text { Lake Corpus } \\
\text { Christi } \\
\text { releases } \\
\end{array}$ & $\begin{array}{l}\text { Erosion and } \\
\text { washoff from } \\
\text { cropland }\end{array}$ & $\begin{array}{l}\text { Erosion and } \\
\text { washoff } \\
\text { from other } \\
\text { land-cover } \\
\text { categories }\end{array}$ & $\begin{array}{c}\text { Erosion } \\
\text { from stream- } \\
\text { channel bed } \\
\text { and banks }{ }^{2}\end{array}$ & $\begin{array}{c}\text { Total } \\
\text { transported } \\
\text { to lower } \\
\text { Nueces } \\
\text { River }^{3} \\
\end{array}$ & $\begin{array}{c}\text { Removed } \\
\text { by water } \\
\text { withdrawals }\end{array}$ & $\begin{array}{c}\text { Total } \\
\text { transported } \\
\text { to Nueces } \\
\text { Estuary }\end{array}$ \\
\hline 1958 & 2,110 & 304 & 26 & 18 & 729 & 1,080 & 16 & 1,060 \\
\hline 1959 & 617 & 70 & 31 & 17 & 87 & 205 & 12 & 193 \\
\hline 1960 & 742 & 70 & 677 & 114 & 74 & 935 & 19 & 916 \\
\hline 1961 & 508 & 45 & 140 & 44 & 79 & 308 & 12 & 296 \\
\hline 1962 & 38 & 5.9 & 0 & 4.7 & 5.1 & 16 & 12 & 3.7 \\
\hline 1963 & 58 & 6.3 & .1 & 7.1 & .9 & 14 & 6.7 & 7.7 \\
\hline 1964 & 421 & 46 & 15 & 9.0 & 77 & 147 & 10 & 137 \\
\hline 1965 & 524 & 64 & 6.2 & 5.0 & 67 & 142 & 10 & 132 \\
\hline 1966 & 601 & 50 & 171 & 57 & 122 & 400 & 14 & 386 \\
\hline 1967 & 2,730 & 616 & 1,240 & 416 & 232 & 2,500 & 11 & 2,490 \\
\hline 1968 & 1,040 & 135 & 39 & 15 & 99 & 288 & 10 & 278 \\
\hline 1969 & 472 & 33 & 668 & 201 & 7.3 & 909 & 14 & 895 \\
\hline 1970 & 559 & 61 & 39 & 16 & 61 & 177 & 11 & 166 \\
\hline 1971 & 3,810 & 647 & 240 & 74 & 296 & 1,260 & 16 & 1,240 \\
\hline 1972 & 462 & 45 & 6.4 & 6.6 & 43 & 101 & 9.3 & 92 \\
\hline 1973 & 1,690 & 203 & 384 & 132 & 95 & 814 & 14 & 800 \\
\hline 1974 & 575 & 61 & 22 & 7.5 & 31 & 122 & 6.8 & 115 \\
\hline 1975 & 509 & 59 & 37 & 11 & 12.9 & 120 & 13 & 107 \\
\hline 1976 & 1,480 & 164 & 38 & 13 & 92 & 307 & 11 & 296 \\
\hline 1977 & 737 & 93 & 4.1 & 3.2 & 18 & 118 & 8.8 & 109 \\
\hline 1978 & 321 & 30 & 18 & 10 & 16 & 74 & 7.1 & 67 \\
\hline 1979 & 589 & 58 & 37 & 15 & 33 & 143 & 9.3 & 133 \\
\hline 1980 & 863 & 112 & 304 & 88 & 28 & 532 & 14 & 518 \\
\hline 1981 & 1,610 & 202 & 124 & 44 & 73 & 443 & 11 & 432 \\
\hline 1982 & 238 & 28 & 4.3 & 4.4 & 4.7 & 41 & 7.7 & 34 \\
\hline 1983 & 115 & 9.0 & 19 & 5.2 & 4.5 & 38 & 7.0 & 31 \\
\hline 1984 & 139 & 7.6 & 32 & 11 & -1.3 & 49 & 5.5 & 44 \\
\hline 1985 & 835 & 72 & 567 & 189 & 24 & 852 & 19 & 833 \\
\hline 1986 & 131 & 13 & .1 & 2.5 & 2.7 & 18 & 5.1 & 13 \\
\hline 1987 & 1,150 & 142 & 147 & 52 & 47 & 388 & 11 & 377 \\
\hline 1988 & 118 & 10 & 155 & 19 & -6 & 178 & 10 & 168 \\
\hline 1989 & 91 & 10 & .2 & 2.9 & -3.4 & 10 & 4.0 & 6.0 \\
\hline 1990 & 454 & 50 & 12 & 4.7 & 2.3 & 69 & 6.6 & 62 \\
\hline 1991 & 256 & 18 & 12 & 7.9 & 12.8 & 51 & 6.0 & 45 \\
\hline 1992 & 1,450 & 156 & 215 & 75 & 50 & 496 & 11 & 485 \\
\hline 1993 & 291 & 23 & 24 & 11 & 11.4 & 69 & 9.0 & 60 \\
\hline
\end{tabular}


Table 15. Estimated annual streamflows and suspended-sediment loads, by sediment source, simulated by the Hydrological Simulation Program—FORTRAN model of the lower Nueces River watershed, South Texas, 1958-2008—Continued.

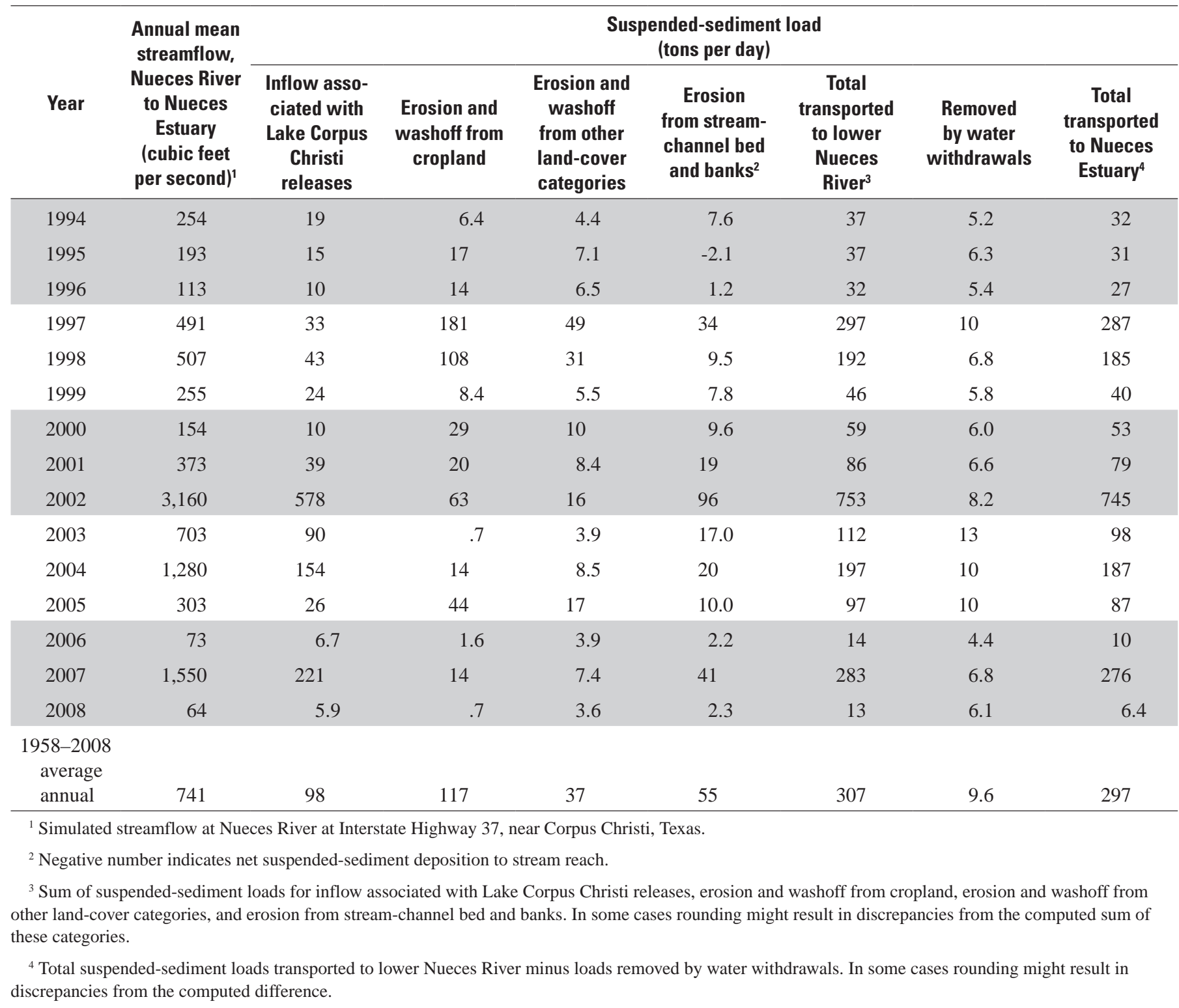

\section{Summary}

The U.S. Geological Survey (USGS), in cooperation with the U.S. Army Corps of Engineers-Fort Worth District, City of Corpus Christi, Guadalupe-Blanco River Authority, San Antonio River Authority, and San Antonio Water System, developed, calibrated, and tested a Hydrological Simulation Program-FORTRAN (HSPF) watershed model to simulate streamflow and suspended-sediment concentrations and loads during 1958-2008 in the lower Nueces River watershed, downstream from Lake Corpus Christi to the Nueces Estuary in South Texas. The loss of sediment loading is an important ecological problem in the Nueces River watershed in South Texas. The reduction in sediment loads to the Nueces Estuary is the result of sedimentation in large impoundments, notably Lake Corpus Christi, a reservoir whose storage volume was greatly enlarged in 1958 compared to its original (1935) impoundment capacity; construction of the 1958 dam expanded the existing storage volume of Lake Corpus Christi from 43,800 to 257,260 acre-feet.

Data available to simulate suspended-sediment concentrations and loads consisted of historical sediment data collected during 1942-82 by the Texas Water Development Board (TDWB) and its predecessor agencies at sites in the study area, and suspended-sediment concentration data collected periodically by the USGS during 2006-07 at three sitesUSGS streamflow-gaging station 08211000 Nueces River near Mathis, Tex. (Mathis gage), station 08211500 Nueces River at Bluntzer, Tex. (Bluntzer gage), and station 08211500 Nueces River at Calallen, Tex. (Calallen gage). 
During 1942-82, TWDB and its predecessor agencies monitored suspended-sediment loads of the Nueces River at a site on the Nueces River at the Mathis gage. The Mathis gage is downstream from Wesley E. Seale Dam, completed in 1958 to impound Lake Corpus Christi. Suspended-sediment data collected before and after completion of Wesley E. Seale Dam provide insights to the effects of the dam and reservoir on suspended-sediment loads transported by the lower Nueces River from downstream of the dam to the Nueces Bay. Suspendedsediment loads measured at the Mathis gage decreased after completion of the dam in 1958. Annual suspended-sediment loads exceeded 100,000 tons during 9 of the 16 years before completion of the dam but during only 2 years after completion of the dam. In the 21 years following completion of the dam, for which reliable suspended-sediment data were available (1962-82), annual suspended-sediment loads were considerably lower, for a given annual mean discharge, than before the dam was completed.

Most of the suspended sediment transported by the Nueces River downstream from Wesley E. Seale Dam occurred during high-flow releases from the dam or during floods. During October 1964-September 1971, about 532,000 tons of suspended sediment were transported by the Nueces River near Mathis. Of this amount, about 473,000 tons, or about 89 percent, were transported by large runoff events (mean streamflow exceeding 1,000 cubic feet per second). Furthermore, the suspended-sediment transport rate increases with higher magnitude flows.

To develop the watershed model to simulate suspendedsediment concentrations and loads in the lower Nueces River watershed, streamflow simulations were calibrated and tested with available data for 2001-08. Streamflow data measured during 2005-08 at the Calallen gage were used to calibrate the model and streamflow data for 2001-04 were used to test the calibrated model. Streamflow data for 2005-06 from the Bluntzer gage were used to test streamflow simulations at that site. Streamflow data from the Mathis gage were used as input to the model at the upstream boundary of the model. Simulated streamflow volumes for the Bluntzer and Calallen gages showed good agreement (within 6 percent) with measured streamflow volumes. Annual, monthly, and daily coefficients of determination of the linear regression between measured and simulated streamflow and Nash-Sutcliffe coefficients of model-fit efficiency are considered acceptable for both gages.

The HSPF model was calibrated to simulate suspended sediment using suspended-sediment data collected at the Mathis, Bluntzer, and Calallen gages during 2006-07. Soil erosion and sediment washoff from various land types simulated by the model were calibrated by comparing simulated suspended-sediment loads from the various land types to estimates of suspended-sediment runoff yields determined from other studies. Parameters related to sediment transport were calibrated primarily by comparing measured suspendedsediment concentrations and loads at the three gages with simulated suspended-sediment concentrations and loads.
The calibrated watershed model was used to estimate streamflow and suspended-sediment loads for 1958-2008, including suspended-sediment loads transported to the Nueces Estuary. During 1958-2008, on average, an estimated 307 tons per day of suspended sediment were delivered to the lower Nueces River; an estimated 297 tons per day were delivered to the estuary. The annual suspended-sediment load was highly variable, depending on the occurrence of storm events and high streamflows. During 1958-2008, the annual total sediment loads to the estuary varied from an estimated 3.8 to 2,490 tons per day. On average, 117 tons per day, or about 38 percent of the estimated annual suspended-sediment contribution, originated from cropland in the study watershed. Releases from Lake Corpus Christi delivered an estimated 98 tons per day of suspended sediment or about 32 percent of the 307 tons per day estimated to have been delivered to the lower Nueces River. Erosion of stream-channel bed and banks accounted for 55 tons per day or about 18 percent of the estimated total suspended-sediment load. All other land categories, except cropland, accounted for an estimated 37 tons per day, or about 12 percent of the total. An estimated 9.6 tons per day of suspended sediment or about 3 percent of the suspended-sediment load delivered to the lower Nueces River were removed by water withdrawals before reaching the Nueces Estuary.

Annual streamflows and suspended-sediment loads to the Nueces River and Nueces Estuary varied depending on rainfall and streamflow conditions. Large rainfall and runoff events contributed most of the streamflow and suspendedsediment loads to the Nueces River. Whether the runoff occurred upstream or downstream from Lake Corpus Christi affected the amount of annual suspended-sediment loads that were contributed by inflows or erosion processes. Simulation results indicate that the largest sediment loads transported to the Nueces Estuary as a result of stream-channel bed and bank erosion occurred during high-flow years and that during low-flow years, large percentages of total suspended sediment transported to the Nueces River were removed by water withdrawals.

\section{References}

Adey, E.A., and Cook, H.M., 1964, Suspended-sediment load of Texas streams - Compilation report, October 1959September 1961: Texas Water Commission Bulletin 6410, $50 \mathrm{p}$.

Aronow, S., and Barnes, V.E, 1975, Geologic atlas of TexasCorpus Christi sheet, Alva Christine Ellisor memorial edition: Austin, University of Texas, Bureau of Economic Geology, GA0010, 1 sheet.

Aronow, S., Brown, T.E., Brewton, J.L., Eargle, D.H., and Barnes, V.E., 1975, Geologic atlas of Texas-BeevilleBay City sheet, Alexander Deussen memorial edition: Austin, University of Texas, Bureau of Economic Geology, GA0005, 5 p., 1 sheet. 
Asquith, W.H., 1999, Areal-reduction factors for the precipitation of the 1-day design storm in Texas: U.S. Geological Survey Water-Resources Investigations Report 99-4267, $81 \mathrm{p}$.

Asquith, W.H., and Roussel, M.C., 2003, Atlas of interoccurrence intervals of selected thresholds of daily precipitation in Texas: U.S. Geological Survey Water-Resources Investigations Report 03-4281, 204 p.

Baird, F.C., Jennings, Marshall, Dybala, T.J., and Ockerman, D.J., 1996, Characterization of nonpoint sources and loadings to the Corpus Christi Bay National Estuary Program study area: Corpus Christi Bay National Estuary Program, CCBNEP-05, $225 \mathrm{p}$.

Bicknell, B.R., Imhoff, J.C., Kittle, J.L., Jr., Donigian, A.S., Jr., and Johanson, R.C., 2001, Hydrological Simulation Program-FORTRAN, users manual for version 12: Research Triangle Park, N.C., U.S. Environmental Protection Agency, National Exposure Research Laboratory, Office of Research and Development, 843 p.

Bidlake, 2002, Evapotranspiration from selected fallowed fields on the Tule Lake National Wildlife Refuge, California, during May to October 2000: U.S. Geological Survey Water-Resources Investigations Report 02-4055, 59 p.

City of Corpus Christi, 2010, City of Corpus Christi official web site-Lake Corpus Christi and Choke Canyon Reservoir: accessed May 29, 2010, at http://www.cctexas. com/? fuseaction $=$ main . view \& page $=1020$.

Cook, H.M., 1967, Suspended-sediment load of Texas streams-Compilation report, October 1961-September 1963: Texas Water Development Board Report 45, 62 p.

Cook, H.M., 1970, Suspended-sediment load of Texas streams-Compilation report, October 1963-September 1965: Texas Water Development Board Report 106, 63 p.

Davis, B.E., 2005, A guide to the proper selection and use of federally approved sediment and water-quality samplers: U.S. Geological Survey Open-File Report 2005-1087, 26 p.

Day, J.W., Jr., Pont, D., Hensel, P.F., and Ibanez, C., 1995, Impacts of sea-level rise on deltas in the Gulf of Mexico and the Mediterranean-The importance of pulsing events to sustainability: Estuaries, v. 18, p. 636-647.

Donigian, A.S., Jr., Bicknell, B.R., and Imhoff, J.C., 1995, Hydrological Simulation Program-FORTRAN (HSPF), in Singh, V.P., ed., Computer models of watershed hydrology: Highlands Ranch, Colo., Water Resources Publications, p. 395-442.

Donigian, A.S., Jr., Imhoff, J.C., Bicknell, B.R., and Kittle, J.L., Jr., 1984, Application guide for Hydrological Simulation Program-FORTRAN (HSPF): Athens, Ga., U.S. Environmental Protection Agency, Environmental Research Laboratory, EPA-600/3-84-065, 177 p.
Donigian, A.S., Jr., and Love, J.T., 2003, Sediment calibration procedures and guidelines for watershed modeling, in TMDL 2003 Specialty Conference, Chicago, Illinois, November 16-18, 2003, Proceedings: Water Environment Federation, accessed January 22, 2010, at http://www.hspf. com/pdf/TMDL2003PaperDonigian.pdf.

Dougherty, J.P., 1979, Suspended-sediment load of Texas streams-Compilation report, October 1971-September 1975: Texas Water Development Board Report 233, 83 p.

Edwards, T.K., and Glysson, G.D., 1999, Field methods for measurement of fluvial sediment: U.S. Geological Survey Techniques of Water-Resources Investigations, book 3, chap. C2, 89 p.

ESRI, 2009, ESRI: accessed January 12, 2008, at http://www. esri.com/.

Fan, H., Huang, H.J., and Zeng, T., 2006, Impacts of anthropogenic activity on the recent evolution of the Huanghe (Yellow) River delta: Journal of Coastal Research, v. 22, p. 919-929.

Farris, O.A., 1933, Silt load of Texas streams: U.S. Department of Agriculture Technical Bulletin 382, 71 p.

Guy, H.P., 1969, Laboratory theory and methods for sediment analysis: U.S. Geological Survey Techniques of WaterResources Investigations, book 5, chap. C1, 58 p.

Handbook of Texas Online, 2009, Mathis, Texas-Facts and information: accessed November 27, 2009, at http://www. tshaonline.org/handbook/online/articles/MM/hfm3.html.

Helsel, D.R., and Hirsch, R.M., 2002, Statistical methods in water resources: U.S. Geological Survey Techniques of Water-Resources Investigations, book 4, chap. A3, version 1.1, accessed online June 14, 2010, at http://pubs.usgs.gov/ twri/twri4a3/.

Homer, C., Huang, C., Yang, L., Wylie, B., and Coan, M., 2004, Development of a 2001 national land-cover database for the United States: Photogrammetric Engineering and Remote Sensing, v. 70, no. 7, p. 829-840.

Jaffe, B.E., Smith, R.E., and Torresan, L.Z., 1998, Sedimentation and bathymetric change in San Pablo Bay, 1856-1983: U.S. Geological Survey Open-File Report 98-759, 11 maps.

Kittle, J.L., Jr., Lumb, A.M., Hummel, P.R., Duda, P.B., and Gray, M.H., 1998, A tool for the generation and analysis of model simulation scenarios for watersheds (GenScn): U.S. Geological Survey Water-Resources Investigations Report 98-4134, 152 p.

Larken, T.J., and Bomar, G.W., 1983, Climatic atlas of Texas: Texas Department of Water Resources, Limited Printing Report LP-192, 151 p. 
Leibbrand, N.F., 1987, Estimated sediment deposition in Lake Corpus Christi, Texas, 1972-85: U.S. Geological Survey Open-File Report 87-239, 26 p.

Linsley, R.K., Kohler, M.A., and Paulhus, J.L., 1982, Hydrology for engineers (3d ed.): New York, McGraw-Hill, $512 \mathrm{p}$.

Lumb, A.M., McCammon, R.B., and Kittle, J.L., Jr., 1994, Users manual for an expert system (HSPEXP) for calibration of the Hydrological Simulation Program-FORTRAN: U.S. Geological Survey Water-Resources Investigations Report 94-4168, 102 p.

Martin, G.R., Zarriello, P.J., and Shipp, A.A., 2001, Hydrologic and water-quality characterization and modeling of the Chenowith Run Basin, Jefferson County, Kentucky: U.S. Geological Survey Water-Resources Investigations Report 00-4239, 197 p.

Minzenmayer, F.E., 1979, Soil survey of Jim Wells County, Texas: U.S. Department of Agriculture, Natural Resources Conservation Service (formerly Soil Conservation Service), 111 p, 50 map sheets.

Mirabal, J., 1974, Suspended-sediment load of Texas streams-Compilation report, October 1965-September 1971: Texas Water Development Board Report 184, 121 p.

Morton, R.A., and Paine, J.G., 1984, Historical shoreline changes in Corpus Christi, Oso, and Nueces Bays, Texas Gulf Coast: Austin, University of Texas, Bureau of Economic Geology Circular 84-6, 66 p.

Multi-Resolution Land Characteristics Consortium, 2008, National land cover database 2001: accessed June 2, 2009, at http://www.mrlc.gov/nlcd.php.

Nash, J.E., and Sutcliffe, J.V., 1970, River flow forecasting through conceptual models, part 1-A discussion of principles: Journal of Hydrology, v. 10, no. 3, p. 282-290.

National Climatic Data Center, 2009, Comparative climatic data for the United States through 2008: Asheville, N.C., National Oceanic and Atmospheric Administration, National Environmental Satellite, Data and Information Service, accessed December 13, 2009, at http://www1.ncdc. noaa.gov/pub/data/ccd-data/CCD-2008.pdf.

Nueces River Authority, 2009, Water usage summary: accessed June 27, 2009, at http://www.nueces-ra.org/CP/ CITY/pipeline.php.

Ockerman, D.J., 2001, Water budget for the Nueces Estuary, Texas, May-October 1998: U.S. Geological Survey Fact Sheet $081-01,6$ p.

Ockerman, D.J., 2002, Hydrologic conditions and quality of rainfall and storm runoff in agricultural and rangeland areas in San Patricio County, Texas, 2000-2001: U.S. Geological Survey Open-File Report 02-291, 20 p., 1 pl.
Ockerman, D.J., and Fernandez, C.J., 2010, Hydrologic conditions and water quality of rainfall and storm runoff for two agricultural areas of the Oso Creek watershed, Nueces County, Texas, 2005-08: U.S. Geological Survey Scientific Investigations Report 2010-5136, 63 p.

Ockerman, D.J., and Petri, B.L., 2001, Hydrologic conditions and water quality in an agricultural area in Kleberg and Nueces Counties, Texas, 1996-98: U.S. Geological Survey Water-Resources Investigations Report 01-4101, 36 p., 2 app.

Ockerman, D.J., and Roussel, M.C., 2009, Simulation of streamflow and water quality in the Leon Creek watershed, Bexar County, Texas, 1997-2004: U.S. Geological Survey Scientific Investigations Report 2009-5191, 50 p.

Ott, R.L., and Longnecker, M., 2001, An introduction to statistical methods and data analysis (5th ed.): Pacific Grove, Calif., Duxbury, 1,152 p.

Phillips, J.D., Slattery, M.C., and Musselman, Z.A., 2005, Channel adjustments of the lower Trinity River, Texas, downstream from Livingston Dam: Earth Surface Processes and Landforms, v. 30, p. 1,419-1,439.

Porterfield, George, 1972, Computation of fluvial-sediment discharge: U.S. Geological Survey Techniques of WaterResources Investigations, book 3, chap. C3, 66 p.

Quincy, R.M., 1988, Suspended sediment load of Texas streams-Compilation report, October 1975-September 1982: Texas Water Development Board Report 306, 153 p.

Raines, T.H., 1996, Simulation of storm peaks and storm volumes for selected subbasins in the West Fork Trinity River Basin, Texas, water years 1993-94: U.S. Geological Survey Water-Resources Investigations Report 96-4110, 41 p.

Rantz, S.E., and others, 1982, Measurement and computation of streamflow-Volume 1. Measurement of stage and discharge: U.S. Geological Survey Water-Supply Paper 2175, 284 p.

Salant, N.L., Renshaw, C.E., and Magilligan, F.J., 2006, Shortand long-term changes to bed mobility and bed composition under altered sediment regimes: Geomorphology, v. 76, p. 43-53.

Singh, V.P., 1995, Watershed modeling, in Singh, V.P., ed., Computer models of watershed hydrology: Highlands Ranch, Colo., Water Resources Publications, p. 1-22.

StatSoft, Inc., 2010, Electronic statistics textbook: accessed June 5, 2010, at http://statsoft.com/textbook/.

Stout, I.M., Bentz, L.C., and Ingram, H.W., 1961, Silt load of Texas streams-A compilation report, June 1889September 1959: Texas Board of Water Engineers Bulletin 6108, 236 p. 
Texas Parks and Wildlife Department, 2007, Plant guidance by ecoregions-Ecoregion 6-South Texas Brush Country: accessed June 6, 2010, at http://www.tpwd.state.tx.us/ huntwild/wild/wildscapes/guidance/plants/ecoregions/ ecoregion_6.phtml.

Texas Water Development Board, 2002, Volumetric survey of Lake Corpus Christi Reservoir: accessed May 29, 2010, at http://www.twdb.state.tx.us/hydro_survey/ CorpusChrisrti2002/CorpusChristi_rpt.pdf.

U.S. Army Corps of Engineers, 2009, Nueces River Basin Reconnaissance Study home page: accessed on May 23, 2009 at $h t t p: / / w w w . s w f . u s a c e . a r m y . m i l / p u b d a t a / n o t i c e s /$ nueces_river_study.asp.

U.S. Bureau of Reclamation, 2000, Rincon Bayou Demonstration Project, concluding report-Volume II, Findings: Austin, Tex., Oklahoma-Texas Area Office, 299 p.

U.S. Department of Agriculture, Natural Resources Conservation Service, 2009, Soil Survey Geographic (SSURGO) database for Texas: accessed July 23, 2009, at http://soildatamart.nrcs.usda.gov/Survey.aspx? State $=$ TX.

U.S. Environmental Protection Agency, 2006, Sediment parameter and calibration guidance for HSPF: U.S. Environmental Protection Agency, EPA BASINS Technical Note 8, accessed October 15, 2009, at http://www.epa.gov/ waterscience/basins/docs/tecnote8.pdf.

U.S. Geological Survey, 2001, Rocky Mountain Mapping Center-Elevation program: accessed October 24, 2007, at http://rockyweb.cr.usgs.gov/elevation/index.html.

U.S. Geological Survey, 2006, National field manual for the collection of water-quality data-Collection of water samples (ver. 2.0): U.S. Geological Survey Techniques of Water-Resources Investigations, book 9, chap. A4, accessed January 15, 2010, at http://pubs.water.usgs.gov/twri9A4/.

U.S. Geological Survey, 2009, National Hydrography Dataset data availability: accessed July 3, 2009, at http://nhd.usgs. gov/data.html.

U.S. Geological Survey, 2010, National Water Information System (NWISWeb) data available on the World Wide Web: accessed September 24, 2010, at http://waterdata.usgs.gov/ tx/nwis/nwis.

Vericat, Damia, Batalla, R.J., and Garcia, Celso, 2006, Breakup and reestablishment of the armour layer in a large gravel-bed river below dams-The lower Ebro: Geomorphology, v. 76, p. 122-136.

Welborn, C.T., 1967, Comparative results of sediment sampling with the Texas sampler and the depth-integrating samplers and specific weight of fluvial sediment deposits in Texas: Texas Water Development Board Report 36, 109 p.

White, W.A., and Calnan, T.C., 1990, Sedimentation in fluvial-deltaic wetlands and estuarine areas, Texas Gulf Coast-Literature synthesis: The University of Texas at Austin, Bureau of Economic Geology, report to Texas Parks and Wildlife Department, $261 \mathrm{p}$.

White, W.A., and Calnan, T.C., 1991, Submergence of vegetated wetlands in fluvial-deltaic areas, Texas Gulf Coast, in Coastal depositional systems in the Gulf of MexicoQuaternary framework and environmental issues: Houston, Society of Economic Paleontologists and Mineralogists, Gulf Coast Section, 12th Annual Research Conference Program with Extended Abstracts, p. 278-279.

White, W.A., Morton, R.A., and Holmes, C.W., 2002, A comparison of factors controlling sedimentation rates and wetland loss in fluvial-deltaic systems, Texas Gulf Coast: Geomorphology, v. 44, p. 47-66.

Wicklein, S.M., and Schiffer, D.M., 2002, Simulation of runoff and water quality for 1990 and 2008 land-use conditions in the Reedy Creek watershed, east-central Florida: U.S. Geological Survey Water-Resources Investigations Report 02-4018, $221 \mathrm{p}$.

Williams, G.P., and Wolman, M.G., 1984, Downstream effects of dams on alluvial rivers: U.S. Geological Survey Professional Paper 1286, 83 p.

Yang, Z., Wang, H., Saito, Y., Milliman, J.D., Xu, K., Qiao, S., and Shi, G., 2006, Dam impacts on the Changjiang (Yangtze) River sediment discharge to the sea-The past 55 years and after the Three Gorges Dam: Water Resources Research, v. 42, no. W04407, 10 p., accessed June 14, 2010, at http://www.agu.org/journals/wr/wr0604/2005WR003970/.

Yeager, K.M., Santschi, P.H., Phillips, J.D., and Herbert, B.E., 2005, Suspended sediment sources and tributary effects in the lower reaches of a coastal plain stream as indicated by radionuclides, Loco Bayou, Texas: Environmental Geology, v. 47, p. 382-395.

Yeager, K.M., Santschi, P.H., Schindler, K.J., Andres, M.J., and Weaver, E.A., 2006, The relative importance of terrestrial versus marine sediment sources to the Nueces-Corpus Christi Estuary, Texas-An isotopic approach: Estuaries and Coasts, v. 29, p. 443-454.

Zarriello, P.J., and Ries, K.G., III, 2000, A precipitation-runoff model for analysis of the effects of water withdrawals on streamflow, Ipswich River Basin, Massachusetts: U.S. Geological Survey Water-Resources Investigations Report 02-4018, 99 p. 
Blank Page 

Appendix 1-Hydrological Simulation Program-FORTRAN (HSPF) Parameters Used to Simulate Hydrologic and Sediment Processes in the Lower Nueces River Watershed, South Texas 
Blank Page 
Appendix 1. Hydrological Simulation Program—FORTRAN parameters used to simulate the hydrologic and sediment processes in the lower Nueces River watershed, South Texas.

[--, none; HSPF, Hydrological Simulation Program-FORTRAN]

\section{Pervious Land (PERLND)}

\begin{tabular}{cccc}
\hline $\begin{array}{c}\text { Secondary } \\
\text { module }\end{array}$ & Parameter & Unit & Description \\
\hline & & Water balance & \\
\hline
\end{tabular}

Interception storage

PWATER CEPSC inch Interception storage capacity

CEPS inch Initial interception storage

\section{Surface and subsurface storages}

UZSN inch

LZSN inch

SURS inch

IFWS inch

UZS inch

LZS inch

AGWS inch
Upper-zone nominal storage; an index to amount of depression and surface-layer storage of a pervious area

Lower-zone nominal storage; an index to soil-moisture-holding capacity

Initial surface storage

Initial interflow storage

Initial upper-zone storage

Initial lower-zone storage

Initial active-groundwater storage

\section{Evapotranspiration}

LZETP

\section{$--$}

AGWETP

BASETP

\section{Recession rates}

KVARY 1/inch

AGWRC 1/day

IRC

$$
1 / \text { day }
$$

GWVS

$$
\text { inch }
$$

\section{Infiltration}

$\begin{array}{lcl}\text { INFILT } & \text { inch/hour } & \text { Index to infiltration capacity of soil } \\ \text { INFILD } & -- & \text { Ratio of maximum to mean infiltration rate of a pervious area } \\ \text { INFEXP } & -- & \text { Infiltration equation exponent } \\ \text { INTFW } & -- & \text { Index to amount of water that infiltrates and flows as interflow (shallow subsurface runoff) } \\ \text { DEEPFR } & -- & \text { Fraction of groundwater inflow to deep recharge }\end{array}$

Groundwater outflow modifier; an index of how much effect recent recharge has on groundwater outflow

Basic groundwater recession rate if KVARY is zero and there is no inflow to groundwater

Interflow recession coefficient

Index to groundwater slope 
Appendix 1. Hydrological Simulation Program-FORTRAN parameters used to simulate the hydrologic and sediment processes in the lower Nueces River watershed, South Texas-Continued.

Pervious Land (PERLND)—Continued

\begin{tabular}{|c|c|c|c|}
\hline $\begin{array}{l}\text { Secondary } \\
\text { module }\end{array}$ & Parameter & Unit & Description \\
\hline \multicolumn{4}{|r|}{ Water balance-Continued } \\
\hline \multicolumn{4}{|c|}{ Overland flow } \\
\hline & LSUR & foot & Average length of overland-flow plane \\
\hline & SLSUR & -- & Average slope of overland-flow plane \\
\hline \multicolumn{4}{|l|}{ Soil erosion } \\
\hline \multirow[t]{6}{*}{ SEDMNT } & SMPF & -- & Management factor to account for use of erosion-control factors \\
\hline & COVER & -- & Fraction of land surface shielded by vegetation or mulch from erosion by direct rainfall impact \\
\hline & NVSI & $\begin{array}{l}\text { pound/acre/ } \\
\text { day }\end{array}$ & Rate at which sediment enters detached-sediment storage from atmosphere \\
\hline & KSER & complex & Coefficient of detached-sediment washoff equation \\
\hline & JSER & complex & Exponent of detached-sediment washoff equation \\
\hline & KGER & complex & Coefficient of matrix soil scour equation \\
\hline
\end{tabular}


Appendix 1. Hydrological Simulation Program-FORTRAN parameters used to simulate the hydrologic and sediment processes in the lower Nueces River watershed, South Texas-Continued.

Impervious Land (IMPLND)

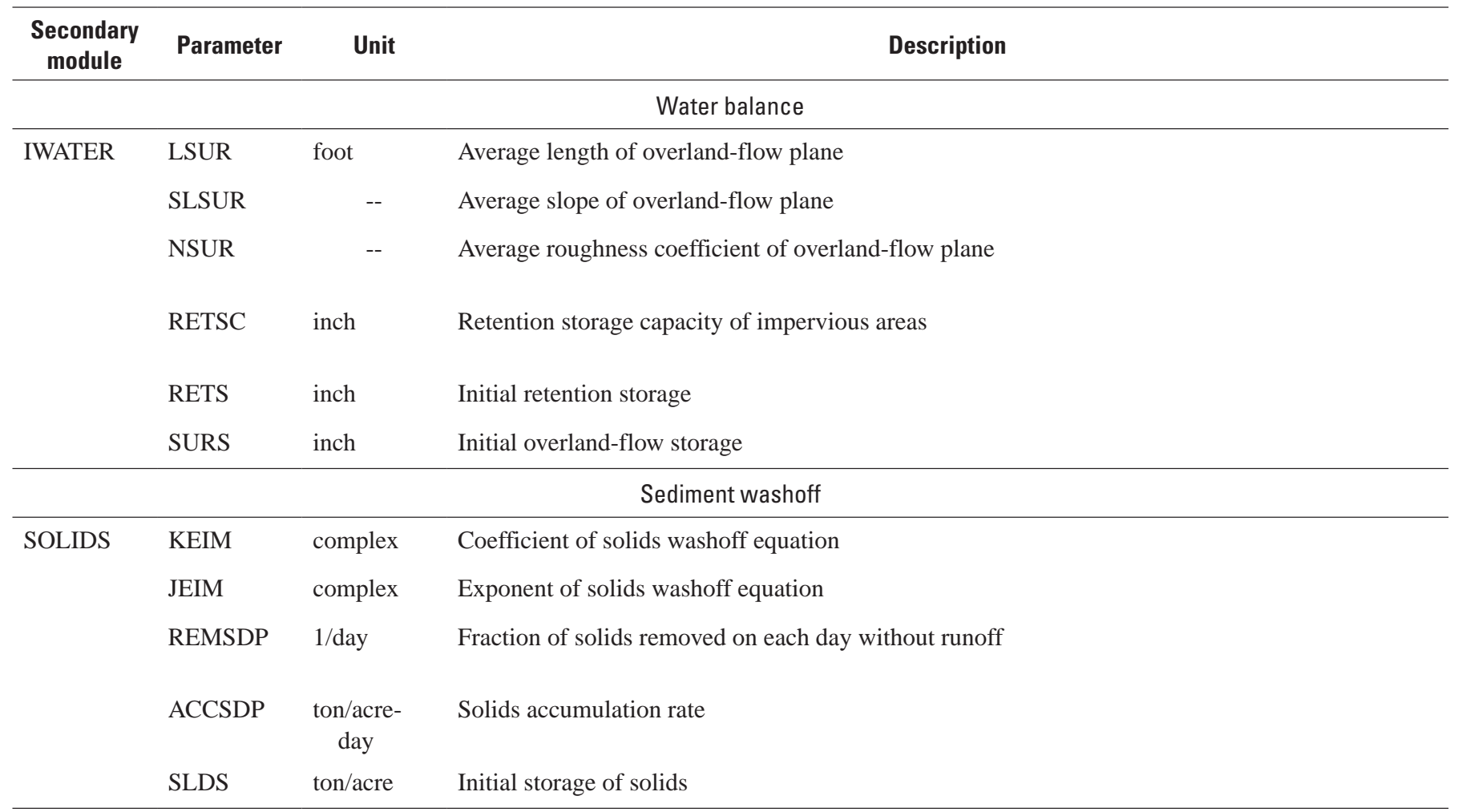

\section{Stream Reaches (RCHRES)}

\begin{tabular}{|c|c|c|c|}
\hline $\begin{array}{c}\text { Secondary } \\
\text { module }\end{array}$ & Parameter & Unit & Description \\
\hline \multicolumn{4}{|r|}{ Water balance } \\
\hline \multirow{4}{*}{ HYDR } & LEN & mile & Length of stream reach \\
\hline & STCOR & foot & Correction in reach depth to calculate stage \\
\hline & KS & -- & Weighting factor for flow routing \\
\hline & DB50 & millimeter & Median diameter of bed sediment \\
\hline
\end{tabular}


Appendix 1. Hydrological Simulation Program—FORTRAN parameters used to simulate the hydrologic and sediment processes in the lower Nueces River watershed, South Texas-Continued.

Stream Reaches (RCHRES)—Continued

\begin{tabular}{|c|c|c|c|}
\hline $\begin{array}{c}\text { Secondary } \\
\text { module }\end{array}$ & Parameter & Unit & Description \\
\hline & & & Sediment transport \\
\hline SEDTRN & BEDWID & foot & Width of streambed \\
\hline & BEDWRN & foot & Depth of streambed \\
\hline & POR & -- & Porosity of streambed \\
\hline & $\mathrm{D}$ & inch & Effective diameter of sediment particle \\
\hline & $\mathrm{W}$ & inch/second & Settling velocity of sediment particle in still water \\
\hline & RHO & $\begin{array}{l}\text { gram/cubic centi- } \\
\text { meter }\end{array}$ & Density of sediment particle \\
\hline & KSAND & complex & Coefficient of HSPF sand-load equation \\
\hline & EXPSND & complex & Exponent of HSPF sand-load equation \\
\hline & TAUCD & pound/square foot & Critical bed shear stress for sediment deposition \\
\hline & TAUCS & pound/square foot & Critical bed shear stress for sediment scour \\
\hline & M & $\begin{array}{l}\text { pound/square } \\
\text { foot-day }\end{array}$ & Erodibility coefficient of sediment \\
\hline & BEDDEP & foot & Initial thickness of bed material \\
\hline & SSAND & milligram/liter & Initial concentration of sand in suspension \\
\hline & SSILT & milligram/liter & Initial concentration of silt in suspension \\
\hline & SCLAY & milligram/liter & Initial concentration of clay in suspension \\
\hline & FRACSAND & -- & Initial fraction by weight of sand in bed material \\
\hline & FRACSILT & -- & Initial fraction by weight of silt in bed material \\
\hline & FRACCLAY & -- & Initial fraction by weight of clay in bed material \\
\hline
\end{tabular}

Publishing support provided by

Lafayette Publishing Service Center

Information regarding water resources in Texas is available at

http://tx.usgs.gov/ 

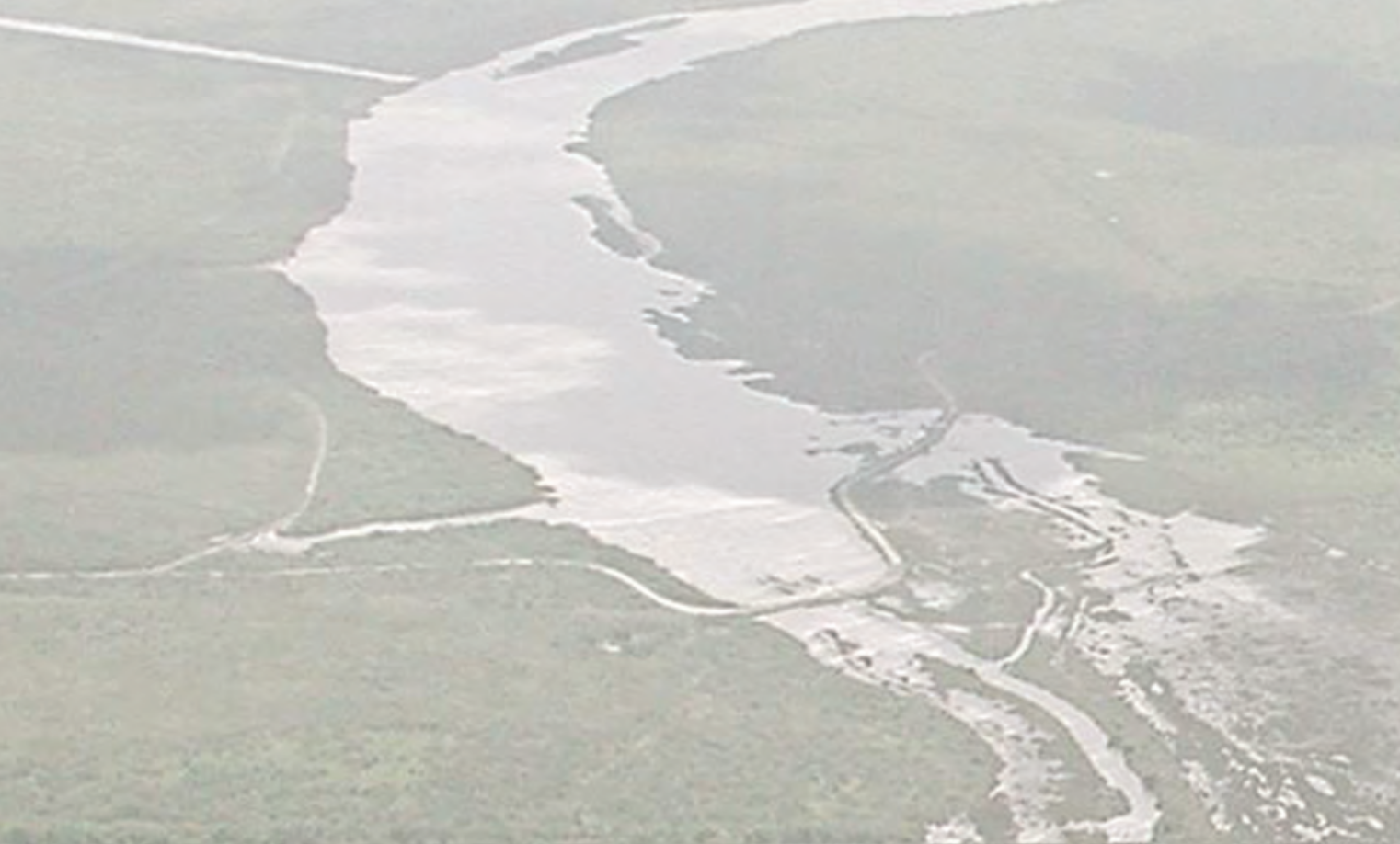

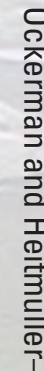
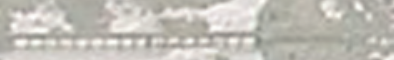